\title{
A FLOOD MODEL FOR THE' TUG FORK BASIN, KENTUCKY, VIRGINIA, AND WEST VIRGINIA
}

By W. Harry Doyle, Jr., Philip B. Curwick and Kathleen M. Flynn 


\title{
UNITED STATES DEPARTMENT OF THE INTERIOR JAMES G. WATT, Secretary
}

\author{
GEOLOGICAL SURVEY \\ Dallas L. Peck, Director
}

For additional information write to:

Copies of this report can

Chief Hydrologist be purchased from:

U.S. Geological Survey, WRD

Open-File Services Section

415 National Center

U.S. Geological Survey

Reston, Virginia 22092

Box 25425, Federal Center

Lakewood, Colorado 80225 


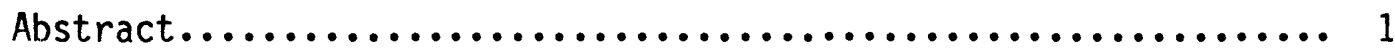

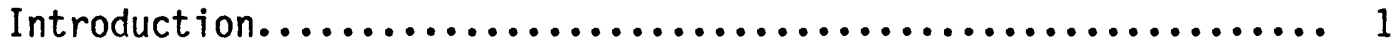

Objectives of study............................ 4

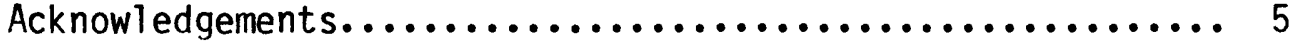

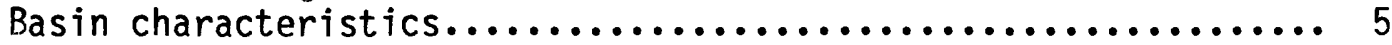

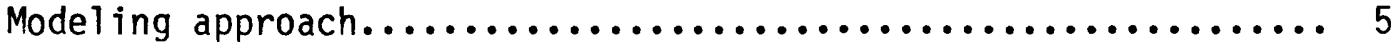

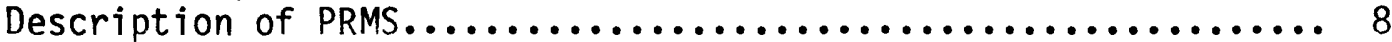

Modifications to PRMS for Tug Fork application.............. 12

Model input data.................................. 12

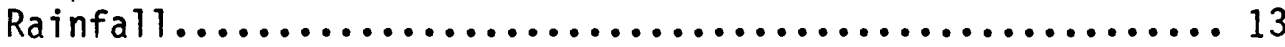

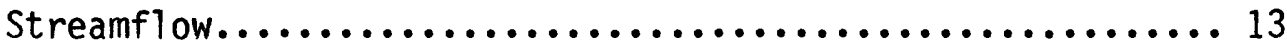

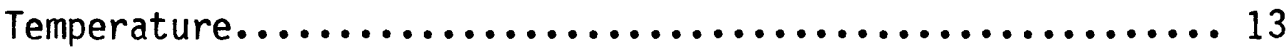

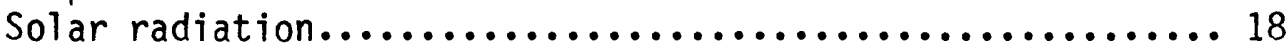

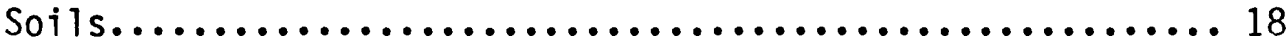

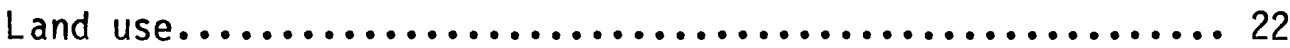

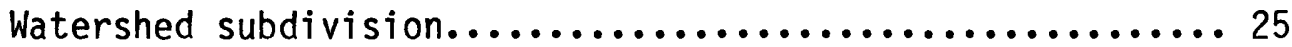

Model calibration and verification..................... 40

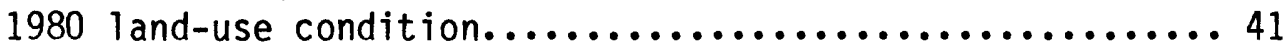

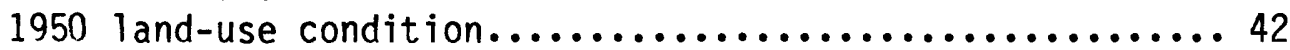

Simulation and frequency analys is of long-term streamflow

time series................................... 46

Detection of hydrologic change........................ 52

Statistical tests for differences.................. 52

Discrepancies in the modeling process................. 54

PRMS application to hypothetical mining land-use scenarios..... 57

Summary........................................ 60

Selected references................................. 62

Appendix A--Model input data........................... 65

Appendix B--Observed and computed mean daily discharge

hydrographs for 11 gaging stations in the Tug Fork basin for

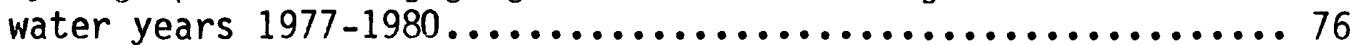


Figure 1. Map showing location of the Tug Fork basin.......... 2

2. Map showing recording precipitation stations, National Weather Service, in or near the Tug Fork basin.............................. 15

3. Map showing continuous-record streamflow-gaging stations in the Tug Fork basin.................. 16

4. Linear relationship of maximum and minimum daily air temperatures for the month of September.......... 17

5. Mean daily solar radiation and Fourier series fit for wet and dry days............................... 19

6. General soil map of Tug Fork basin............... 20

7. Map showing Tug Fork basin subdivided into 30 subareas for determining land-use information...... 24

8. Map showing locations of subbasins where model information needed......................... 39

9. Observed and computed mean daily discharge hydrographs for Tug Fork at Litwar, W. Va., for water years 1979 and $1980 \ldots \ldots \ldots \ldots \ldots \ldots \ldots \ldots . . . .64$

10. Observed and computed mean daily discharge hydrographs for Tug Fork at Litwar, W. Va., for water years 1952 and $1953 . \ldots \ldots \ldots \ldots \ldots \ldots \ldots \ldots . .48$ 
Table 1. Fifteen reference points in Tug Fork basin selected for model output generation..................... 7

2. Major hydrologic processes and characteristics of Precipitation-Runoff Modeling System.......... 9

3. Recording National Weather Service precipitation in or near the Tug Fork basin.................... 14

4. Soil series of the Tug Fork River basin............ 21

5. Physical descriptors of soils in the Tug Fork basin... 23

6. Summary of land-use information for Tug Fork basin during $1950-1980 \ldots \ldots \ldots \ldots \ldots \ldots \ldots \ldots \ldots \ldots . . . . .26$

7. Summary of 1 and use in the Tug Fork basin for 1950,

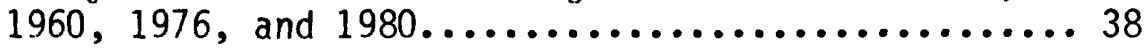

8. Selected measured and assigned basin characteristics for the 1980 land-use condition..................43

9. Drainage areas corresponding to the early period (1950) land-use conditions for each hydrologic response unit............................. 47

10. Difference between observed and computed streamflow at station 03213000 , Tug Fork at Litwar, W. Va...... 49

11. Difference between observed and computed streamflow at station 03213500, Panther Creek near Panther, W. Va.............................. 50

12. Difference between observed and computed streamflow at station 03214000, Tug Fork near Kermit, W. Va.... 51

13. Frequency analys is results for Tug Fork stations for 1950 and 1980 basin conditions, annual 1-day

high streamflow in cubic feet per second........... 53

14. Results of Mann-Whitney nonparametric statistical test for homogeneity between the 1950 and 1980 streamflow time series....................... 55

15. Frequency analyses for observed, 1950-1980 calibration, 1950-calibration, 1960-calibration, and 1980-calibration streamflow data for Panther Creek near Panther, W. Va......................... 56

16. Hypothetical increases in surface mining applied to 85.8-square-mile basin, Tug Fork at Welch, W. Va., annual 1-day high streamflow in cubic feet per second..................................... 58

17. Comparison of present and worst case mining scenario for entire Tug Fork basin, annual 1-day high streamflow in cubic feet per second. 
METRIC CONVERSIONS

Inch-pound units in this report may be converted to International System of Units (SI) of measurements by the following conversion factors:

Multiply Inch-pound units

By To obtain SI units

\begin{tabular}{|c|c|c|}
\hline inch (in) & 25.4 & millimeter $(\mathrm{mm})$ \\
\hline foot $(f t)$ & 0.3048 & meter $(m)$ \\
\hline mile (mi) & 1.6093 & kilometer $(\mathrm{km})$ \\
\hline acre & 0.4047 & hectare (ha) \\
\hline square foot $\left(\mathrm{ft}^{2}\right)$ & 0.0929 & square meter $\left(\mathrm{m}^{2}\right)$ \\
\hline square mile $\left(m i^{2}\right)$ & 2.590 & square kilometer $\left(\mathrm{km}^{2}\right)$ \\
\hline cubic foot per second $\left(\mathrm{ft}^{3} / \mathrm{s}\right)$ & 0.02832 & cubic meter per second $\left(\mathrm{m}^{3} / \mathrm{s}\right)$ \\
\hline ton, short & 0.9072 & megagram $(\mathrm{Mg})$ or metric ton $(t)$ \\
\hline
\end{tabular}

langleys per day

41840

joules per square meter per day 
A FLOOD MODEL FOR THE TUG FORK BASIN, KENTUCKY,

VIRGINIA, AND WEST VIRGINIA

By W. Harry Doyle, Jr., Philip B. Curwick, and Kathleen M. Flynn

ABSTRACT

Surface mining of coal in the United States increased from 406 million tons to almost 800 millions tons from 1978 to 1979. In the coal-rich 1,560-square-mile Tug Fork basin located in Kentucky, Virginia, and West Virginia, there has been a 2,500 percent increase since 1950 in areas affected by surface-mining activities.

This study used a rainfall-runoff model to determine if 1 anduse changes associated with surface mining in the Tug Fork basin have affected basin streamflow characteristics. The model was calibrated and verified for two periods, one representing 1980 1 and-use and one representing 1950 land-use. Two 29-year synthetic daily streamflow time series representing the two land-use conditions were generated. Statistical tests performed on the two time series at 15 points in the basin showed no difference at the 0.01 percent confidence level at any of the locations.

In addition, analyses were made to determine if future increases in surface-mining activities might affect basin streamflow. One analysis showed that increasing mining in an upland watershed by as much as 200 percent had little effect on streamflow in the intermediate area and no effect on streamflow at downstream locations along the Tug Fork. Even for a scenario where all areas disturbed by mining were assumed totally impervious, the modeling process demonstrated that the increase in mean-annual 1-day high flows (for recurrence intervals of $2,5,10,25,50,100$, and 200 years) was less than 4 percent at the basin outlet.

\section{INTRODUCTION}

The Tug Fork basin, a 1,560-square-mile mountainous area of Kentucky, Virginia, and West Virginia (fig. 1), is underlain by extensive coal deposits comprising a significant part of the nation's coal reserves. The low-sulfur characteristics of the coal deposits in the basin make it an important product that is used in the iron and steel industries in the United States and in European markets. The coal-mining industry provides the main livelihood of those living in the area. Mining is prevalent throughout the basin. 

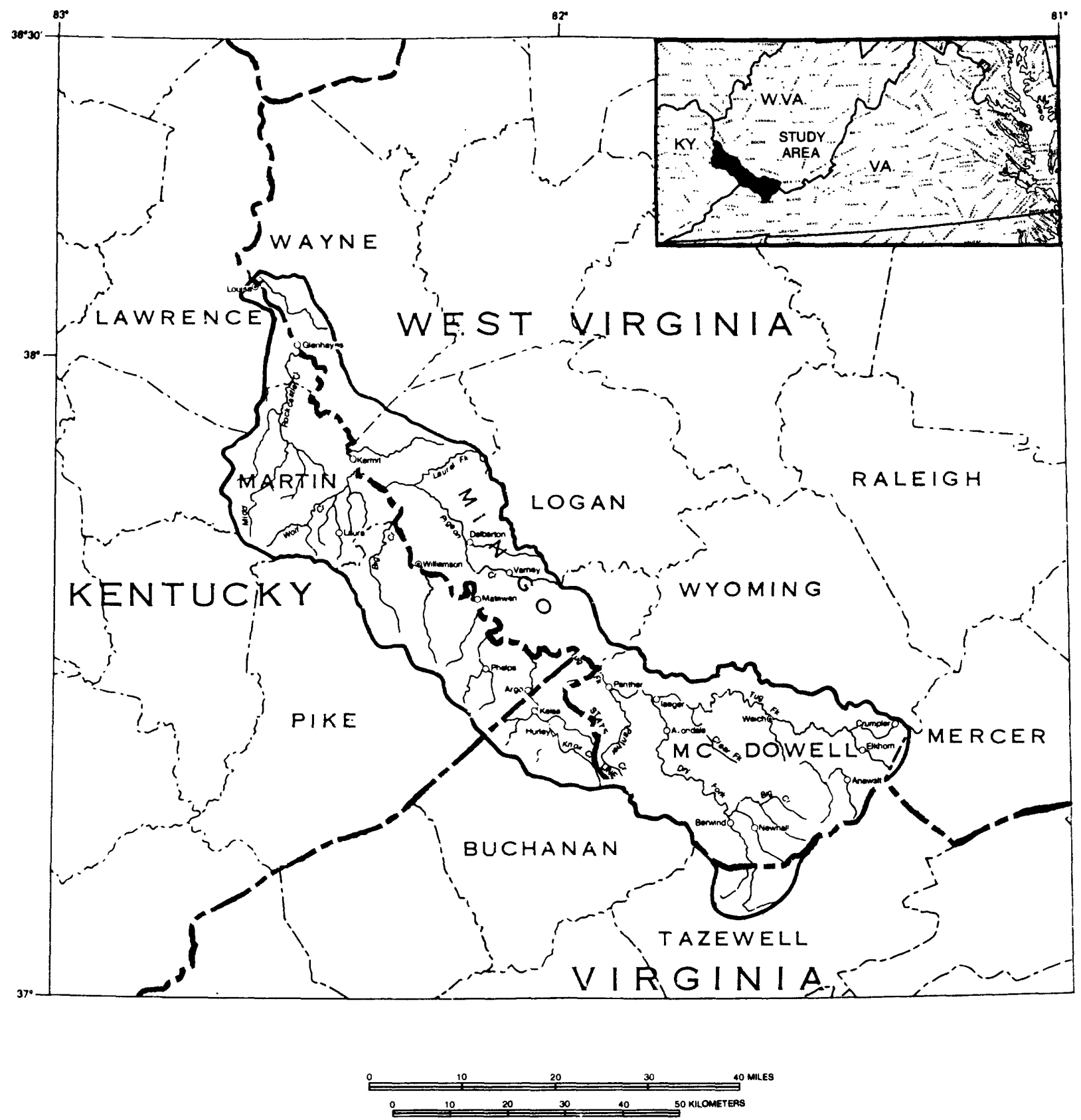

Figure 1.--Location of the Tug Fork basin. 
There is much concern that surface-mining activities may have affected the characteristics and patterns of storm runoff in the basin since 1950. Periodic flooding on many watersheds in the region such as the major flood in April 1977 (Runner, 1979; Runner and Chin, 1980) is speculated to be the result of surface-mining operations in the area. With 166 billion tons of coal in reserve, there is certain to be land-use changes in the future that may affect flooding in the basin. A calibrated and verified precipitation-runoff model that can simulate streamflow for different conditions is needed to analyze the effects of past, present and future landuse scenarios.

The U.S. Geological Survey, in cooperation with the U.S. Bureau of Mines and the Office of Surface Mining Reclamation and Enforcement, began a study in early 1980 in the Tug Fork basin (Scott, 1980). The objectives of the study were (1) to identify relative effects of the various land-use changes on flood characteristics, (2) to assess the effectiveness of present mine-reclamation practices for controlling undesirable aspects of storm runoff, and (3) to observe and analyze cumulative impacts of typical land-use changes on sediment and flood characteristics at downstream points in the Tug Fork basin.

The approach outlined in the study plan for achieving the first objective consisted of statistical analyses on existing data and a precipitation-runoff modeling effort that would continuously simulate streamflow for both the entire basin and on each of 10 small watershed sites implemented for the study. The model for the entire basin also could be used to analyze cumulative impacts of typical land-use changes.

The results of statistical analyses (Hirsch and others, 1982), based on selected long-term discharge records alone, indicated that annual flood peak characteristics in the Tug Fork basin exhibit an increasing trend. However, the report stated that this trend even persisted in undisturbed and relatively unmined parts of the basin. One conclusion was that there is no direct evidence that the increase in annual flood peaks is related to surface mining or that the increase was too small to detect with the existing data and trend analysis techniques. Although these statistical analyses showed that flood peaks in the basin have slightly increased, they could not conclusively identify the causative factors that affected these changes. The changes could have been the result of climate, channel modifications, surface mining, other environmental factors or a combination of these factors. 
A later report (Scott and Hirsch, 1982) summarized results of a statistical analysis made of historical partial-duration peakflow data and sequential land-use data from 1950 through 1980 for the Tug Fork basin. This subsequent analysis indicated an increasing trend in the magnitude of smaller flood peaks at a stream gaging site in the upper part of the Tug Fork basin at the same time that land disturbance related to surface mining also increased. As before, no increase in the magnitude of larger floods was evident. For a gage in the lower part of the Tug Fork basin no statistically significant (at a 10 percent level of confidence) evidence of change was found. The difference in results for the two gages may reflect the greater concentration of 1 and disturbance near the upstream Tug Fork gage and the location of the surface mining within the Tug Fork basin.

\section{Objectives of Study}

The next approach to detect the impact of surface-mining activities on the flooding in the Tug Fork basin is to use a precipitation-runoff model. This technique eliminates climatic changes as a cause for increased flooding. If climate is not the cause and channel modifications have been shown not to occur (Hirsch and others, 1982), one concludes that surface-mining activities must be the cause as no other major changes can be identified. The precipitation-runoff modeling effort encompassed the following tasks:

1. Cal ibrate and verify a mathematical watershed model for the Tug Fork basin with streamflow records for both 1950 and 1980 land-use conditions.

2. Use long-term (1951-1980) rainfall data with each modeled condition to provide two simulated streamflow records at 15 principal points of interest in the basin.

3. Statistically analyze the simulated streamflow records produced for 1950 and 1980 land-use conditions to detect any change.

4. Compare simulated streamflow difference resulting from land-use changes with possible discrepancies in the modeling process that may be overshadowing any computed differences.

5. Apply the model with a range of assumptions and future hypothetical land-use changes to illustrate possible hydrologic consequences. 
A major part of the study involved compiling and analyzing historic data. The authors are indebted to those who supplied the required information. In particular, we acknowledge the assistance of Survey personnel in Kentucky, Virginia, and West Virginia who provided streamflow data; Ken Harmon, Chief, Hydraulics and Hydrology Branch, and Kenneth Halstead, Hydraulic Design Section, Huntington District, U.S. Army Corps of Engineers, Huntington, W. Va., for river cross-sectional and hydraulic data; Soil Conservation Service Soil Scientists in the above three states for soils data; and the National Weather Service Center in Asheville, N.C., for climatological data.

\section{BASIN CHARACTERISTICS}

The Tug Fork basin (fig.1) has a drainage area of nearly $1,560 \mathrm{mi}^{2}$ and extends from the headwaters near the Virginia-West Virginia state line, northwest until its waters join the Levisa Fork at Louisa, Ky. The basin is characterized by narrow river valleys bordered by steeply rising mountains. The major river in the basin is the Tug Fork which winds through the basin for about $150 \mathrm{mi}$. For much of this length, the Tug Fork serves as the political boundary between Kentucky and West Virginia. Scott (1980) characterized in detail basin physiography, topography, and geology.

Climate in the area is characterized by moderately severe winters with frequent alternations of fair and stormy weather and hot, showery summers. Temperatures range from a mean minimum of $28^{\circ} \mathrm{F}$ in January to a mean maximum of $88^{\circ} \mathrm{F}$ in July. Mean annual precipitation is about 44 inches which includes snowfall in the colder months. Intense rainfall occurs periodically and is a common source of flooding. Runoff in the basin is generally highest during February and March and lowest during September and October. The maximum observed discharge in the basin was $104,000 \mathrm{ft}^{3} / \mathrm{s}$ which occurred on the Tug Fork River at Kermit, W. Va., during April 1977.

\section{MODEL ING APPROACH}

The Precipitation-Runoff Modeling System (PRMS) (G. H., Leavesley, written commun., 1982) developed by the Geological Survey was chosen to be applied to the Tug Fork basin. The liabilities of inadequate rainfall data and the large size of watershed segments for hydrologicprocesses definition were recognized as possible limitations of a fully successful watershed modeling application. The modeling approach, however, was assumed valid based on earlier studies in the basin (Lumb, 1982). PRMS was developed to evaluate the impacts of various combinations of precipitation, climate, and land-use on surface-water runoff, sediment yields, and general basin hydrology. The modeling system has the capability of computing soil-moisture deficits based upon inputs to and losses from the watershed. Rainfall and snowmelt not added to surface or soil moisture storages can be routed overland and through comprehensive channel networks. 
Although PRMS can simulate streamflow in the daily mode or shorter time interval (5-minute, 15-minute, 1-hour, and so forth) unit mode, it was decided that only the daily mode would be used and the mean daily streamflow analyzed instead of instantaneous streamflow. Also, the size of the basin would make it very difficult to represent surface-mined disturbed areas as overland flow planes as required in the unit mode.

Fifteen points (table 1) were selected in the Tug Fork basin at which streamflow data were desired. The basin was subdivided into individual watersheds with the 15 points of interest each being an outlet of a subwatershed. Eleven of the 15 points have observed streamflow data while four are ungaged sites. The ungaged sites along the Tug Fork River are near tributary confluences that represent a significant change in contributing drainage area. The most downstream gaging station considered was Tug Fork at Glenhayes, W. Va., although the study area is shown to extend to Louisa, Ky., (fig. 1) to provide continuity with other reports of the area. Backwater from the Levisa Fork affects flow and invalidates model flow computations downstream from this station.

PRMS was calibrated and verified for two periods during 19501980, the earlier pre-mined period in 1950 and the later period in 1980 reflecting the increase in surface-mining activities. The 1980 period was modeled first because streamflow data at 11 gaging stations were available to compare with model-generated streamflow.

The approach involved applying the model to both periods with each of the 15 subwatersheds having disturbed areas designated as mined and reclaimed. These disturbed areas were assigned flatter slopes reflecting the effect of mining. Cover densities, soil covers, precipitation interception storage of vegetation, amount of solar radiation received, and other variables were also varied for the mined and reclaimed areas.

Using this approach, the model was calibrated and verified in the daily mode for both 1980 and 1950 periods. In the 1950 period, mined and reclaimed areas were identified and the model was checked at the three active stream gages. Continuous daily rainfall data from 1951 to 1980 were used with both calibrated models and simulated mean-daily streamflow time series were generated at all 15 points of interest. Annual maximum daily frequency analyses were performed on the 1950 and 1980 simulated streamflow series. Using several nonparametric statistical tests, a determination was made as to whether or not land-use changes have caused statistically significant hydrologic changes in streamflow patterns and characteristics. 


\begin{tabular}{|c|c|c|c|c|c|}
\hline $\begin{array}{l}\text { Reference } 1 / \\
\text { point }\end{array}$ & $\begin{array}{l}\text { Station } \\
\text { identification }\end{array}$ & Station name or location & $\begin{array}{l}\text { Drainage } \\
\text { area } \\
\qquad\left(m i^{2}\right)\end{array}$ & $\begin{array}{l}\text { Period of } \\
\text { record }\end{array}$ & $\begin{array}{c}\text { River mile } \\
\text { location } \\
\text { along } \\
\text { Tug Fork } \\
\text { (mi) }\end{array}$ \\
\hline A & 03212700 & Elkhorn Creek at Maitland, W. Va. & 73.3 & $.1979-1980$ & $2 / 134.85$ \\
\hline B & 03212600 & Tug Fork at Welch, W. Va. & 85.8 & $1979-1981$ & 135.80 \\
\hline C & --- & $\begin{array}{l}\text { On Tug Fork below confluence } \\
\text { of Elkhorn Creek and Tug Fork } \\
\text { downstream from city limits of } \\
\text { Welch, W. Va. }\end{array}$ & 162 & Ungaged & 134.45 \\
\hline$D$ & --- & $\begin{array}{l}\text { On Tug Fork at Iaeger, W. Va., } \\
1 \text { mi upstream of confluence of } \\
\text { Dry Fork and Tug Fork }\end{array}$ & 268 & Ungaged & 110.70 \\
\hline $\mathrm{E}$ & 03212985 & Dry Fork at Avondale, w. Va. & 225 & $1979-1981$ & $109.70 *$ \\
\hline $\mathrm{F}$ & 03213000 & Tug Fork at Litwar, W. Va. & 505 & 1930-present & 107.00 \\
\hline G & 03213500 & Panther Creek near Panther, W. Va. & - 31.0 & 1946-present & $103.10 *$ \\
\hline$H$ & --- & $\begin{array}{l}\text { On Tug Fork below confluence of } \\
\text { Panther Creek and Tug Fork }\end{array}$ & 562 & Ungaged & 102.60 \\
\hline I & --- & $\begin{array}{l}\text { On Tug Fork at Matewan, W. Va., } \\
14.8 \text { mi downstream of confluence } \\
\text { of Knox Creek and Tug Fork }\end{array}$ & 874 & Ungaged & 70.50 \\
\hline I2 & 03213590 & Knox Creek near Kelsa, Va. & 84.3 & $1980-1981$ & $85.30 *$ \\
\hline J & 03213700 & Tug Fork at Williamson, W. Va. & 936 & 1967-present & 57.40 \\
\hline K & 03213800 & Pigeon Creek near Lenore, W. Va. & 93.9 & $1979-1981$ & $41.60 *$ \\
\hline L & 03214000 & Tug Fork near Kermit, W. Va. &, 188 & 1934-present & 38.40 \\
\hline M & 03214700 & Rockcastle Creek near Inez, Ky. & 63.1 & $1980-1981$ & $10.20 *$ \\
\hline N & 03214900 & Tug Fork at Glenhayes, W. Va. &, 507 & 1976-present & 9.50 \\
\hline
\end{tabular}

1/See figure 7 for location of reference point.

2/Tributary to Tug Fork River and river mile location refers to point where tributary confluences with Tug Fork. 
The investigation also demonstrated that additional consideration should be given to identifying "modeling noise" that might be responsible for producing a detected statistical difference between the 1950 and 1980 simulations. Modeling noise includes input-data errors, streamflow-measurement errors, discrepancies between the model processes and real watershed processes, and errors in parameter calibration. Therefore, a comprehensive analys is was performed on the smallest, least-disturbed watershed, Panther Creek near Panther, W. Va. This 31-square-mile basin has experienced very little surface mining during the last 30 years and any difference in estimating observed discharges can be attributed to "modeling noise."

Additionally, an analysis was made with the calibrated 1980 model for a hypothetical future land-use scenario representing a significant increase in mining activity. This kind of application can show what would happen to the streamflow characteristics if surface mining continues to increase in the basin. Also, a worstcase scenario for the 1980 condition was modeled to determine a maximum-possible alteration to streamflow.

\section{DESCRIPTION OF PRMS}

PRMS was developed by the Geological Survey to evaluate the hydrologic impacts of land-use changes. Table 2 lists some of the major hydrologic processes and characteristics of PRMS. Both rainfall and snowmelt events can be simulated on a watershed to evaluate changes in the hydrologic balance due to activities such as surface mining. PRMS will simulate mean daily flows (daily mode) and shorter time interval storm hydrographs (unit mode).

It is a distributed-parameter model with two levels of partitioning available to the user. In the first level, the user subdivides the watershed into hydrologic response units (HRUs) on the basis of characteristics such as land use, vegetation type, soil type, and precipitation distribution. Each resulting HRU is assumed to produce a unique and homogeneous hydrologic response. A water balance and energy balance are computed daily for each HRU. The sum of the responses of all HRUs weighted on a unit-area basis produces the daily system response and streamflow from a basin. PRMS will accommodate a maximum of 50 HRUs.

A second level of partitioning is available for delineating overland flow plane and channel segments for the purpose of routing surface runoff and channel flow in the unit mode. An HRU can be considered the equivalent of a flow plane or it can be subdivided into a number of flow planes. PRMS will handle a combined total of 100 overland flow plane and channel segments. 
Table 2.--Major hydrologic processes and characteristics of PrecipitationRunoff Modeling System

HYDROLOGIC PROCESSES

Interception

Infiltration

Surface runoff

Evapotranspiration

Soil moisture storage

Percolation

Subsurface flow

Ground-water flow

Channel flow routing
Assigned maximum storage, computed as a function of cover density and depth of storage available.

Green-Ampt equation for unit storm computation.

Contributing area concept for daily computation; kinematic wave hydraul ic routing of rainfall excess for unit storm computation.

Actual rate limited by moisture storage; three computational procedures are available to compute potential -- (1) direct use of evaporation pan data, (2) function of daily mean air temperature and possible hours of sunshine, and (3) function of daily mean air temperature and solar radiation.

Two-layer soil-moisture storage; field capacity specified to each layer; water balance between rainfall and snowmelt infiltration, evapotranspiration, and recharge to subsurface and ground-water storage reservoirs.

Takes place in excess of soil-moisture field capacity and user-specified recharge rate.

Nonlinear function of available storage volume and user-specified routing coefficients.

Linear function of available storage volume and user-specified routing coefficients.

Solution of continuity equation and Manning formula assuming uniform flow condition for unit storm computations; none for daily computations. 
Table 2.--Continued

HYDROLOGIC PROCESSES--Continued

Reservoir routing

Two computational procedures available:

(1) solution of continuity equation and linear storage function; or (2) modifiedPuls.

Snow accumulation and melt

Based on theoretical accumulation and melt equations; snowpack is maintained and modified both on a water-equivalent basis and as a dynamic-heat reservoir.

\section{OTHER CHARACTERISTICS}

Rainfall input

Basin configuration

Parameter representation

Calibration
Multiple rain gages (as many as three) may be used as input.

Distributed segment.

Distributed.

Automatic parameter optimization with sensitivity analyses. 
The watershed system is conceptualized as a series of linear or nonlinear cascading storage elements. The model has three of these storage elements: (1) upper soil-zone reservoir, (2) subsurface reservoir, and (3) ground-water reservoir. The upper soil-zone is treated as a two-layered system. Subsurface flow is considered to support the recession of storm-flow hydrographs and can be defined as either a linear or nonlinear reservoir. The ground-water reservoir is a linear reservoir and is the source of all base flow. Total streamflow is the sum of the output of each reservoir. For daily flow simulations, no channel routing is performed. Therefore, in the daily mode, PRMS simulates hydrologic processes as daily averages or total values. Streamflow is computed as a mean daily flow.

The model is structured into four general components with regard to the hydrologic cycle. These are the climatic, land phase, snow, and sediment components. The climatic component accepts input time-series data from one climatic station and adjusts these data to define the climate over the watershed on a daily basis. The land phase component simulates the processes of interception, infiltration, evapotranspiration, soil-water accounting, surface runoff, and subsurface and ground water flow. Surface runoff in the daily mode is computed using a contributing-area concept. In the unit mode, surface runoff is computed using a variation of the Green-Ampt point infiltration equation (Green and Ampt, 1911; Mein and Larson, 1973). Point infiltration is converted to an areal value for each HRU using a linear relationship between point infiltration and rainfall supply rate. This rainfall excess is subsequently routed overland and through channels using a finite difference approximation of the solution of the one-dimensional equations of continuity and momentum with the kinematic wave simplification.

The snow component simulates the initiation, accumulations, and depletion of a snowpack on each HRU. A snowpack is maintained and modified on both a water-equivalent basis and as a dynamic heat reservoir. A snowpack balance is computed daily and an energy balance is computed twice each day for two 12-hour periods.

Optimization and sensitivity components included in PRMS aid in adjusting model parameters. The user can potentially optimize 42 model parameters to obtain better agreement between computed and observed runoff. There are three objective functions in the optimization routine: (1) absolute difference between observed and predicted discharge, (2) square of the differences, and (3) square of the differences of the logarithmic values. When sensitivity analysis is coupled with optimization, the user also can assess the magnitude of parameter standard errors and parameter intercorrelations.

PRMS is designed to operate with data retrieved from the WATSTORE (Showen, 1978) data storage and retrieval system of the Geological Survey. However, for data not stored on the WATSTORE system, programs are available to read and convert these data into a model compatible format. 
PRMS was modified before it was calibrated in the daily mode. Surface, subsurface, and groundwater discharge contributions are computed daily for each HRU. The model combines these discharges from all HRUs to produce a total streamflow at the basin outlet. There is no daily streamflow routing performed by PRMS. Total traveltime in the Tug Fork Basin from the headwaters to the outlet at Glenhayes, W. Va. was determined to be approximately three days for most flow regimes. It was estimated that it takes about one day traveltime between the following locations in the basin:

1. From headwaters on the West Virginia-Virginia border to Litwar, W. Va.;

2. From Litwar, W. Va., to Williamson, W. Va.; and

3. From Williamson, W. Va., to Glenhayes, W. Va.

The model was modified to account for this traveltime. Discharges from HRUs in the upper part of the basin were lagged two days, from HRUs in the middle part of the basin one day, and then added to discharge from the lower HRUs to produce total streamflow at 14 other locations in the basin taking into account the appropriate lag times where necessary. Simulated streamflow from all 15 points of interest (table 1) were stored in data files for later analyses.

Flow attenuation was not directly considered in this modification of PRMS. Flow attenuation results from overbank and channel storage. The narrow river valleys and adjacent steeply rising mountains promote little attenuation of streamflow as it moves through the basin. Also, it has been shown repeatedly in channelrouting applications, that the kinematic wave approximation used in PRMS in the unit mode always predicts a steeper wave with less dispersion and attenuation than may actually occur.

\section{MODEL INPUT DATA}

Basically, two types of data are required to run PRMS in the daily-flow mode: (1) time-series; and (2) physical descriptors. Necessary daily time-series data included rainfall, streamflow (used for comparison purposes), maximum and minimum air temperature, and solar radiation.

Physical descriptors describing the drainage area, slope, aspect, elevation, and so forth; soil characteristics; and vegetal cover were obtained from (1) topographic maps at a scale of 1:250,000, (2) general statewide soil maps, or (3) by judgment and previous experience. Land-use data were obtained from maps at a scale of 1:50,000 and will be discussed in a later section of the report. 
Rainfall data is by far the single most important time-series in any watershed modeling study. Numerous investigations, for example, Dawdy and Bergmann (1969), Troutman (1981), and Johanson (1971) bear out this fact. Therefore, a careful analysis was made of all available rainfall data located in or near the Tug Fork basin. Consideration of areal coverage, orographic effects, model limitations, and completeness of record all influence the choice of which station to use for modeling purposes.

Fifteen long-term rain gages were identified for possible use in the study (table 3 and fig. 2). Because only three precipitation records can be used in this model, the following three stations were selected to provide the best spatial coverage and most complete records: (1) 3353 Gary at Gary, W. Va.; (2) 9610 Williamson 2 at Williamson, W. Va.; and (3) 4946 Louisa at Louisa, Ky.

\section{Streamflow}

The Geological Survey operates 11 gaging stations that provided continuous records of streamflow in the Tug Fork basin for this study. Table 1 lists these sites along with station number, name, drainage area, period of record, and river-mile location along the Tug Fork. The locations of these sites are shown in figure 3. Oniy 3 of the 11 gages have continuous records since 1950 or earlier: 03213000 Tug Fork at Litwar, W. Va.; 03213500 Panther Creek near Panther, W. Va.; and 03214000 Tug Fork near Kermit, W. Va. All streamflow data were retrieved from the WATSTORE system of the Geological Survey.

\section{Temperature}

A preliminary analysis of the data from 11 National Weather Service (NWS) air-temperature stations, located in or near the Tug Fork basin, was made to determine which gage, if any, had adequate record needed for the study. The analysis identified two stations with a sufficient length of concurrent maximum and minimum air temperature records: 3350 Gary, W. Va., and 9605 Wi11iamson, W. Va. Further study of the records at these two stations revealed that the Gary gage had the least number of days with missing record and was therefore chosen for model input.

Periods of missing records were reconstructed from the data from both stations so the records would be complete. The procedure used can be illustrated with reference to figure 4 . Historic data were used to relate air temperatures recorded at Williamson to those at Gary. A relation was derived for each month for both maximum and minimum daily air temperatures using linear leastsquares theory. Missing records at Gary were computed from these relationships and data available at the Williamson station. 
Table 3.--Recording National Weather Service precipitation stations in or near the Tug Fork basin

\begin{tabular}{|c|c|c|c|c|}
\hline \multirow[t]{2}{*}{ Name } & \multirow{2}{*}{$\begin{array}{c}\text { Station } \\
\text { No. }\end{array}$} & \multicolumn{2}{|c|}{ Location } & \multirow{2}{*}{$\begin{array}{l}\text { Periodl/ } \\
\text { of record }\end{array}$} \\
\hline & & Latitude & Longitude & \\
\hline \multicolumn{5}{|c|}{ TUG FORK BASIN } \\
\hline Davella, Ky. & 2053 & $37^{\circ} 48^{\prime}$ & $82^{\circ} 35^{\prime}$ & 1940-present. \\
\hline Freeburn, Ky. & 3046 & $37^{\circ} 33^{\prime}$ & $82^{\circ} 10^{\prime}$ & 1951-present. \\
\hline Hurley, Va. & 4180 & $37^{\circ} 25^{\prime}$ & $82^{\circ} 01^{\prime}$ & 1964-present. \\
\hline Kermit, W. Va. & 4816 & $37^{\circ} 50^{\prime}$ & $82^{\circ} 24^{\prime}$ & 1942-present. \\
\hline Williamson, w. Va. & 9605 & $37^{\circ} 40^{\prime}$ & $82^{\circ} 17^{\prime}$ & 1940-present. \\
\hline Williamson 2 NNW, W. Va. & 9610 & $37^{\circ} 42^{\prime}$ & $82^{\circ} 17^{\prime}$ & 1951-present. \\
\hline Iaeger, W. Va. & 4408 & $37^{\circ} 28^{\prime}$ & $81^{\circ} 49^{\prime}$ & 1942-present. \\
\hline Gary, W. Va. & 3353 & $37^{\circ} 22^{\prime}$ & $81^{\circ} 33^{\prime}$ & 1941-present. \\
\hline
\end{tabular}

ADJACENT BASINS

Kentucky

$\begin{array}{lllll}\text { Burdine 2 NE } & 1120 & 37^{\circ} 13^{\prime} & 82^{\circ} 35^{\prime} & 1951 \text {-present. } \\ \text { Louisa 2 SW } & 4946 & 38^{\circ} 07^{\prime} & 82^{\circ} 38^{\prime} & 1941 \text {-present. } \\ \text { Pikeville 2 } & 6355 & 37^{\circ} 29^{\prime} & 82^{\circ} 32^{\prime} & 1934 \text {-present. } \\ \text { Meta 4 SE } & 5370 & 37^{\circ} 32^{\prime} & 82^{\circ} 23^{\prime} & 1958 \text {-present. }\end{array}$

Virginia

Davenport $2 \mathrm{NE} \quad 2269 \quad 37^{\circ} 07^{\prime} \quad 82^{\circ} 06^{\prime} \quad 1940$-present.

West Virginia

Flat Top

3072

$37^{\circ} 35^{\prime} \quad 81^{\circ} 06^{\prime}$

1940 -present.

Logan

5353

$37^{\circ} 51^{\prime} \quad 82^{\circ} 00^{\prime}$

1941-present.

1/May include short periods of missing records. 

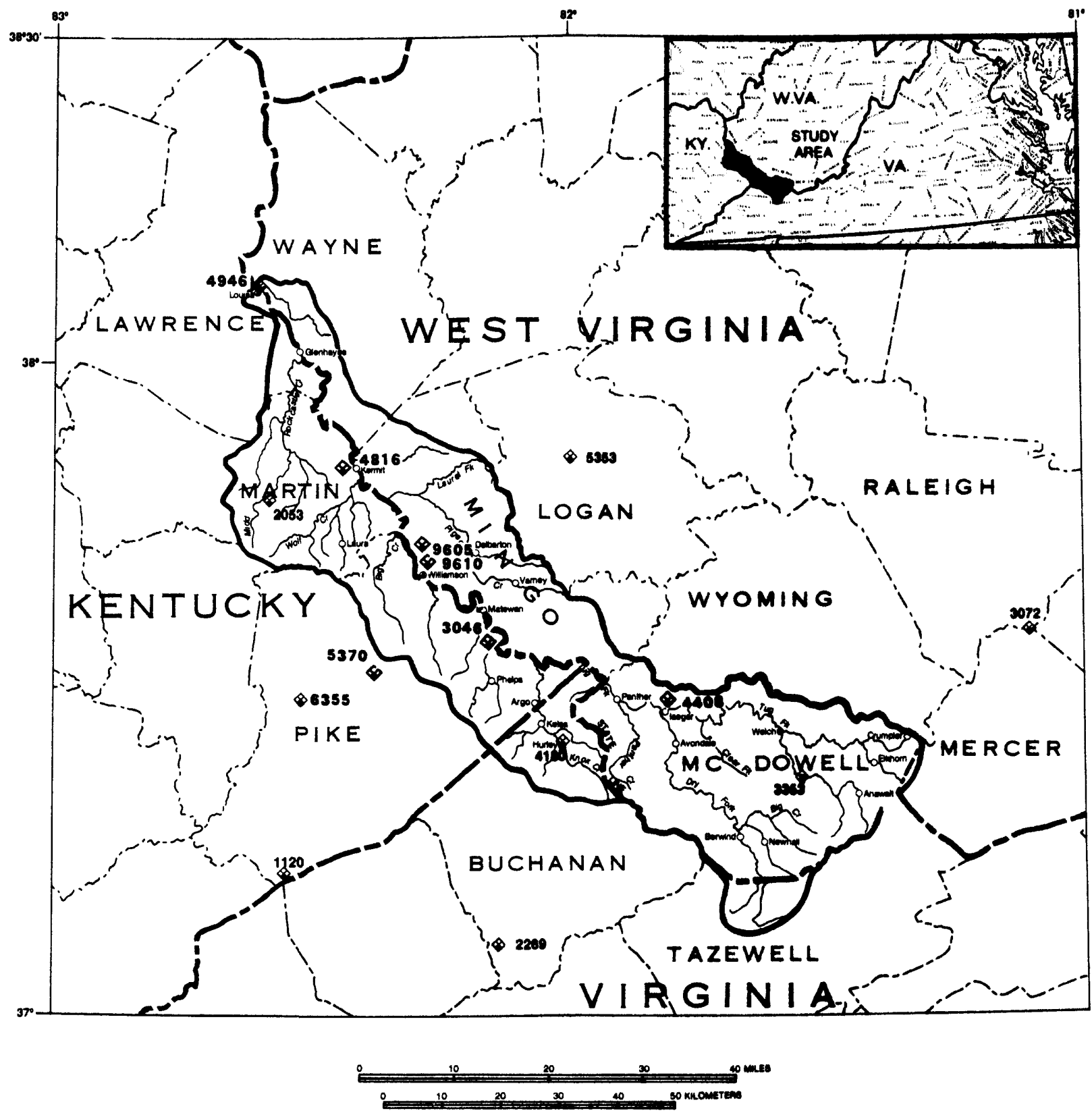

Figure 2.--Recording precipitation stations, National Weather Service, in or near the Tug Fork Basin. 


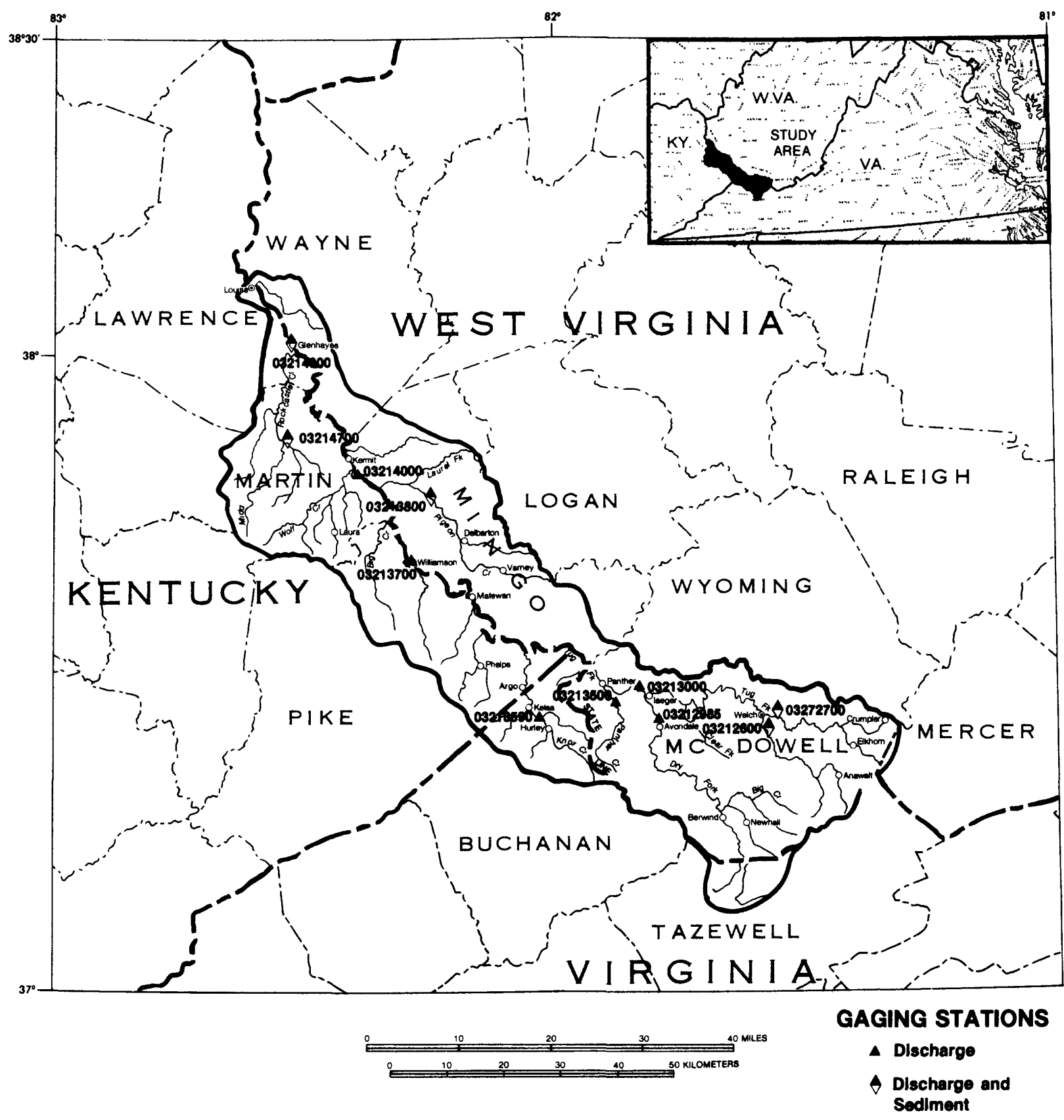

Figure 3.--Continuous-record streamflow-gaging stations in the Tug Fork basin. 


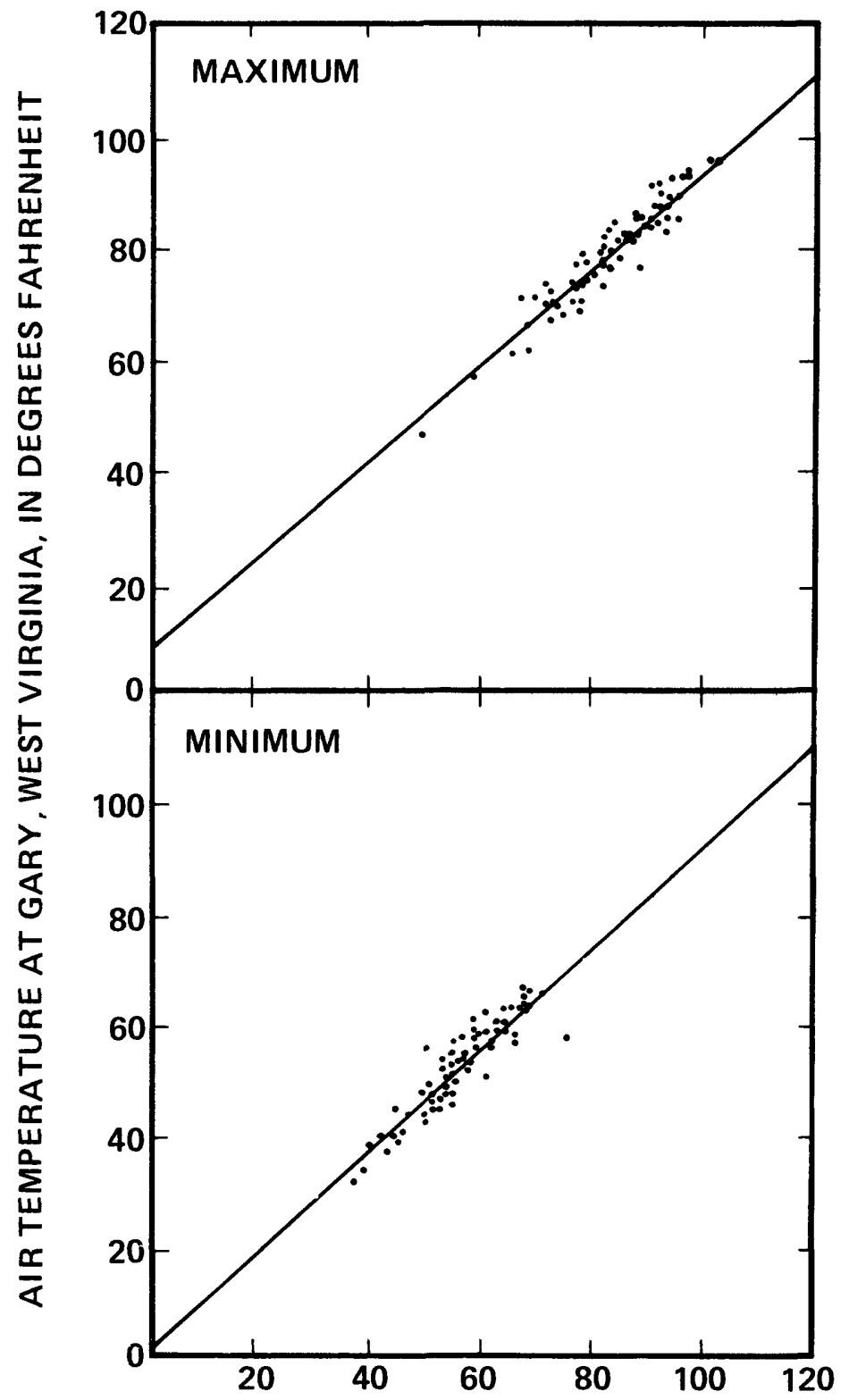

AIR TEMPERATURE AT WILLIAMSON, WEST VIRGINIA, IN DEGREES FAHRENHEIT

Figure 4.--Linear relationship of maximum and minimum daily air temperatures for the month of September. (Data points plotted for the 1st, 15th, and 30th days of month for illustrative purposes only) 
The nearest long-term station was used to provide the solar radiation data for modeling purposes. The data were recorded by the University of Kentucky, Agricultural Engineering Department, in Lexington, Ky. Lexington is approximately $160 \mathrm{mi}$ west of the centroid of the Tug Fork basin. Data has been collected at this site since 1967. However, considerable missing record existed in the data. The missing records were reconstructed by fitting a Fourier series with least squares theory to the available data. For wet days the solar radiation time-series was approximated as

$$
S_{W}(t)=220.18+\left[-138.68 \cos \left(\frac{2 \pi t}{365}\right)+31.31 \sin \left(\frac{2 \pi t}{365}\right)\right]
$$

where

$$
\begin{aligned}
t & =j u l i a n \text { day }(1-365), \text { and } \\
S_{W}(t) & =\text { solar radiation on day } t \text { when it rains. }
\end{aligned}
$$

For dry days the solar radiation time-series was approximated as

$$
S_{D}(t)=362.55+\left[-172.78 \cos \left(\frac{2 \pi t}{365}\right)+43.40 \sin \left(\frac{2 \pi t}{365}\right)\right]
$$

where

$$
\begin{aligned}
t & =\text { julian day }(1-365), \text { and } \\
S_{D}(t) & =\text { solar radiation on day } t \text { when it does not rain. }
\end{aligned}
$$

These relations are shown superimposed on plots of mean daily solar radiation for 1975-79 in figure 5 .

\section{Soils}

Soil surveys have not been completed by the Soil Conservation Service for all counties in the Tug Fork basin. Instead, data compiled from statewide general soil maps (U.S. Dept. of Agriculture, 1975, 1979a, and 1979b) and soil interpretation records were used to determine the physical descriptors of the soils for modeling purposes.

The general soil map for the Tug Fork basin is shown in figure 6. This map shows the distribution of different soil associations in the basin. The soil associations were named for the two or three major soil series that occur in the area and are listed in table 4. Since the general soil map does not show the spatial extent of individual soil series, it was assumed that each series was uniformly distributed and occurred in equal proportion within a soil association. 


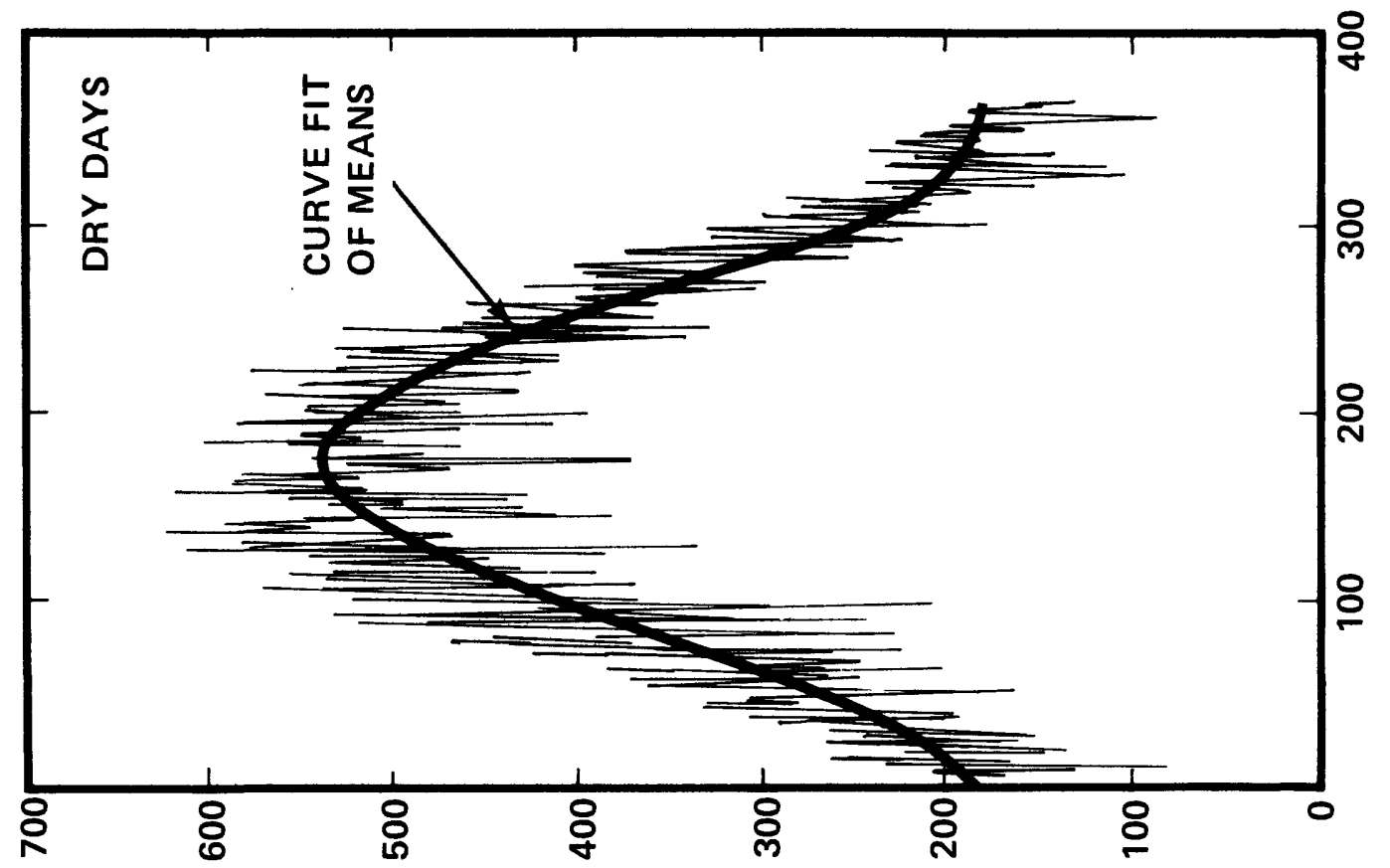

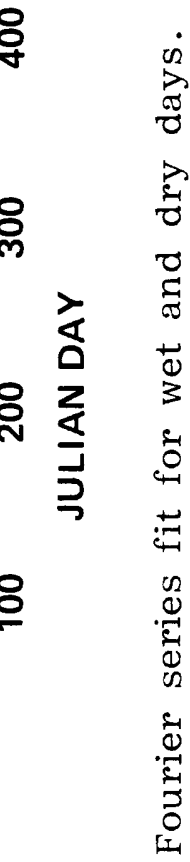

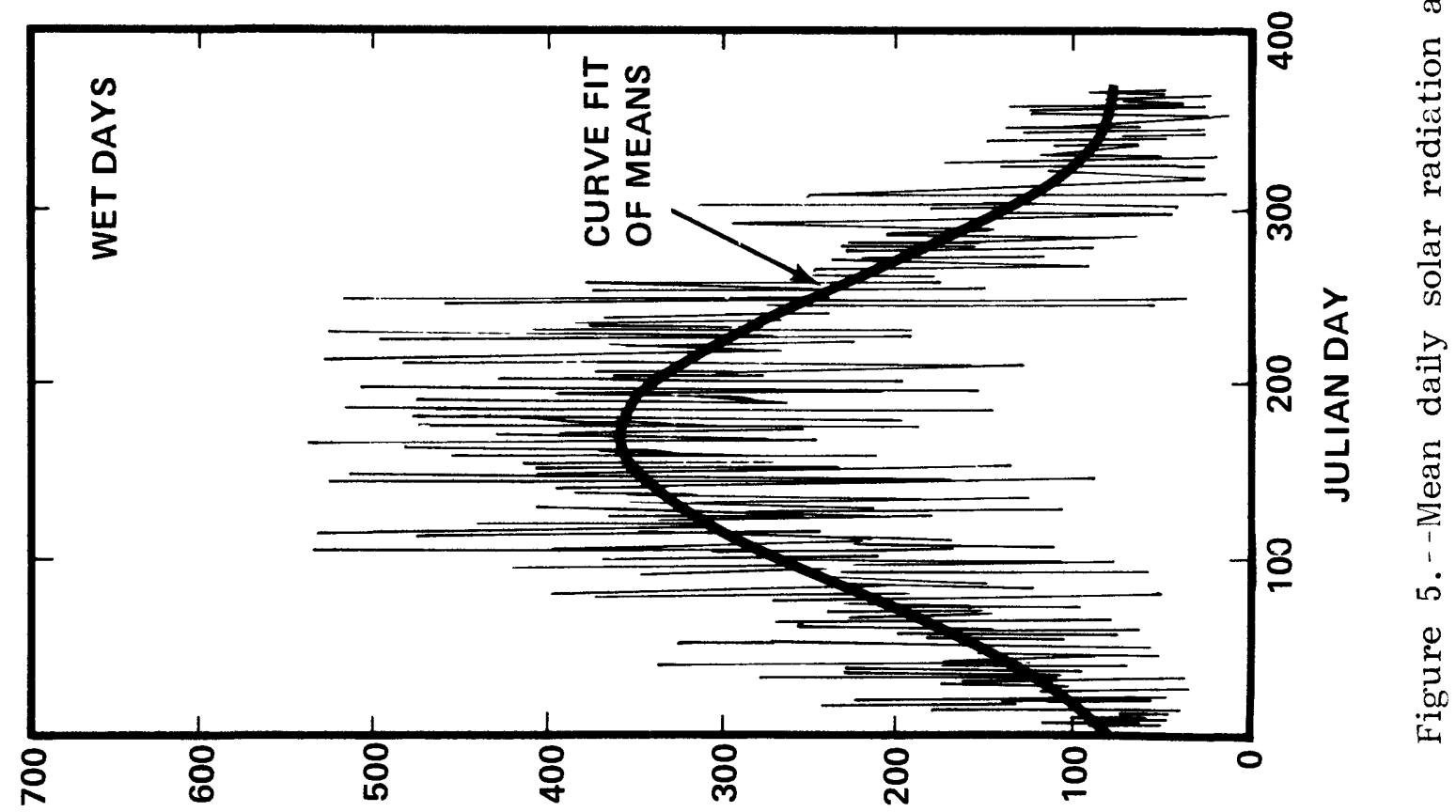

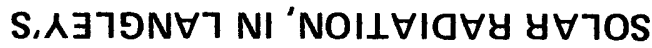



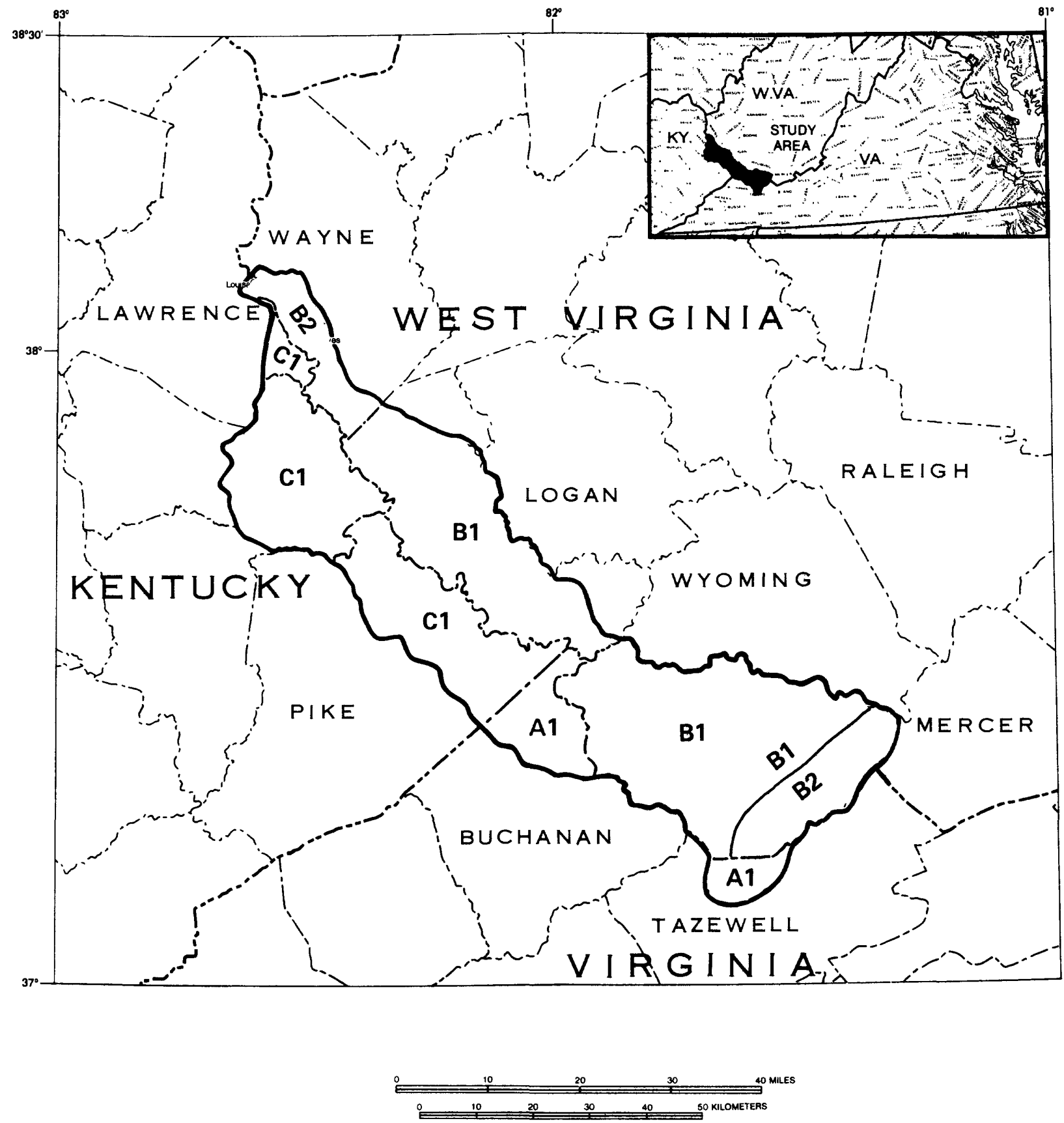

Soil Associations

A1 DeKalb-Berks-Weikert

B1 Clymer-DeKalb-Jefferson

B2 Clymer-Gilpin

C1 Jefferson-Shelocta

Figure 6.--General soil map of Tug Fork basin. 
Table 4.--Soil series of the Tug Fork River basin

Soil Association

Series

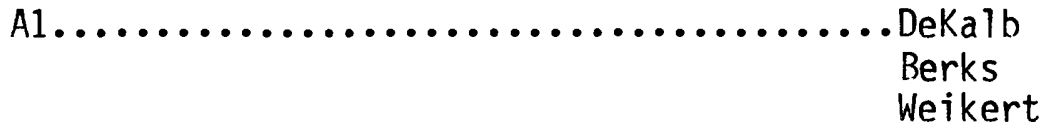

B1.............................. Clymer

DeKalb

Jefferson

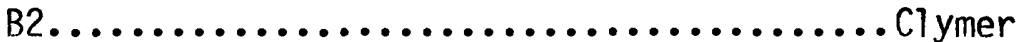

Gilpin

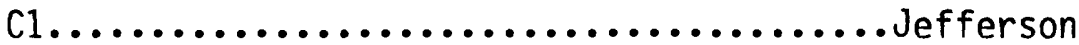

Shelocta 
The physical descriptors of the soils in the basin are listed in table 5. The soils are classified as loams and silty loams according to the U.S. Department of Agriculture textural classification system. The maximum water-holding capacities varied between 0.06 and $0.14 \mathrm{in./in}$. The depth of the hydrologically active part of the soil mantle was taken as either the depth to the water table or depth to bedrock, whichever was shallowest. This depth ranged from 20 to 65 in.

\section{Land Use}

The Tug Fork basin was subdivided into 30 subwatersheds as shown in figure 7 . The 15 selected points (table 1) where streamflow data are required are outlets at some of the subareas and are shown by letters $A-N$. The remaining subareas were selected so that a better representation of the basin could be made for modeling purposes.

Land-use maps of the Tug Fork basin for the years 1950, 1960, 1976, and 1980 (scale 1:50,000) were prepared by the Geological Survey. The following land-use categories were used:

1. Urban.--Relatively dense concentration of residential, commercial, or industrial buildings in a single area. All areas were mapped that were a minimum of 10 acres and were over 300 feet wide.

2. Active mining.--Areas of current surface mining. The surface is freshly disturbed with no visible signs of regrading, reconstruction, or revegetating. No minimum size.

3. Inactive mining.--Areas of recent surface mining, probably within the past 1 or 2 years, but no sign of current activity. No backfilling, reconstruction, or revegetation has occurred. No minimum size.

4. Reclaimed.--Areas previously disturbed by surface mining and that have been reclaimed naturally or by reconstruction including areas where natural revegetation has occurred and areas where regrading has taken $\mathrm{place}$ but revegetation has not occurred. No minimum size.

5. Associated mining.--These surface areas include all coal tipples, coal-processing areas, coal-storage areas, waste piles, and other industrial areas directly associated with coal mining. A11 areas exceeding 10 acres and over 300 feet in width were mapped.

6. Logged areas.--Areas that have been either selectively cut or clear cut for timber. All areas exceeding 40 acres were mapped.

7. Agriculture.--Crop and pasture areas. All areas exceeding 10 acres were mapped. 
Table 5.--Physical descriptors of soils in the Tug Fork basin

\begin{tabular}{clccc}
\hline Soil & & $\begin{array}{c}\text { Textural } \\
\text { class }\end{array}$ & $\begin{array}{c}\text { Available water- } \\
\text { holding capacity } \\
\text { (in./in.) }\end{array}$ & $\begin{array}{c}\text { Depth of } \\
\text { soil profile } \\
\text { (in.) }\end{array}$ \\
\hline \multirow{2}{*}{ A1 } & Dekalb & Silt loam & 0.09 & 40 \\
& Berks & Loam & .07 & 40 \\
& Weikert & Loam & .06 & 20 \\
B1 & Clymer & Silt loam & .09 & 60 \\
& Dekalb & Silt loam & .09 & 40 \\
& Jefferson & Silt loam & .12 & 65 \\
B2 & Clymer & Silt loam & .09 & 60 \\
& Gilpin & Silt loam & .12 & 65 \\
C1 & Jefferson & Silt loam & .12 & 50 \\
& Shelocta & Silt loam & .14 & \\
\hline
\end{tabular}




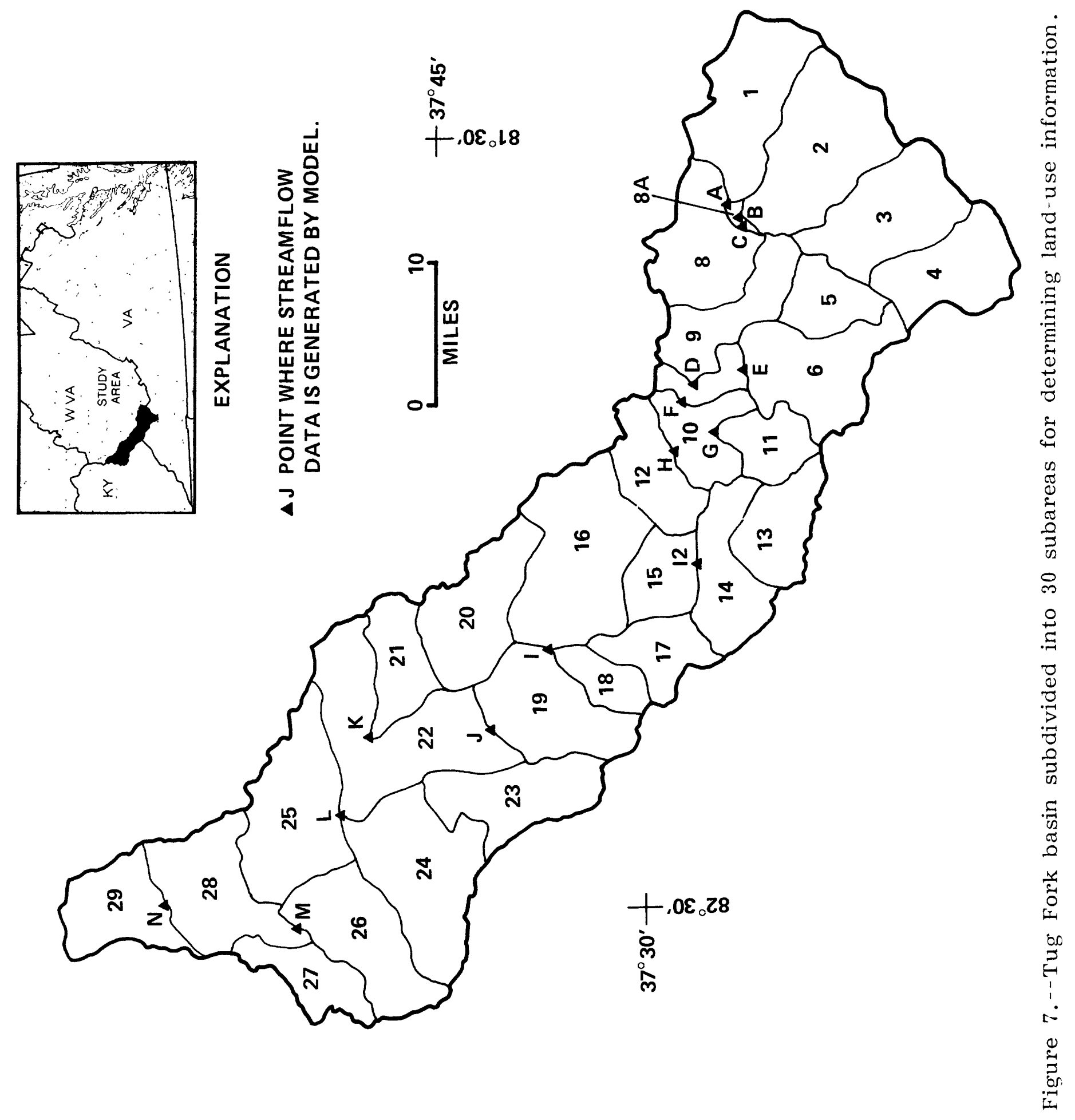


8. Improved roads.--Paved roads defined as heavy duty, medium duty, or Tight duty. Lengths of roads were determined for all areas of basin (including urban) and an assumed width of 24 feet was used to compute areas.

9. Undeveloped roads.--All unimproved dirt roads for which an assumed width of 24 feet was used to compute areas.

10. Ponds.--All ponds and lakes exceeding 5 acres were mapped.

Table 6 lists land-use areas (in acres) by subarea for each category for 1950, 1960, 1976, and 1980. In addition, the total surface area disturbed by mining activities (sum of land-use categories 2-5 above) also is listed in table 6. Table 7 1 ists summary information for each of the four years and by category. These data were used to define cover densities, disturbed areas, and to provide other information required by the model. Subarea 29 (fig. 7) which is below Tug Fork at Glenhayes, W. Va., was not included in tables 6 and 7 tabulations.

As seen in table 7 , mining activities increased significantly between 1950 and 1980. It can also be seen that agriculture in the same period decreased 78 percent. This information substantiates how important mining is in the Tug Fork basin, and with the large coal reserves, how it will continue to remain important. Overall, since 1950 there has been a decrease of just over 4 percent $(97.17$ to 93.07) in the undisturbed part of the basin. These areas are mostly forested, consisting primarily of deciduous hardwoods with some scattered conifers.

\section{Watershed Subdivision}

One of the first steps in watershed modeling is subdivision of the watershed into smaller homogeneous HRU subareas. These HRUs are assumed to produce a unique hydrologic response for a given combination of climate, topography, land-use, and soil condition. No totally objective criteria exist on how to subdivide the watershed and this is currently a topic of research. Watershed modelers must therefore employ subjective criteria to accomplish this step.

Study needs dictated that streamflow be simulated at 15 locations in the Tug Fork basin. These sites are shown in figure 8 (letters $A-N$ ) and identified in table 1. Nine sites are on the main stem of the Tug Fork ( 4 of which are ungaged) and the remaining six sites are on tributaries to the Tug Fork. Each drainage area associated with these sites was then subdivided on the basis of 1 and use. Three land-use types were considered: mined, reclaimed, and "other." Mined areas included the active, inactive, and associated mined areas described earlier. The "other" land-use type consisted primarily of deciduous forest with a small percentage of urban and agriculture areas also included. With these considerations, the entire Tug Fork basin was subdivided into 44 model segments or HRUs. The subarea whose outlet was at reference point $F$ was the only one without a land-use type "reclaimed" in either 1950 or 1980. 
Table 6.--Summary of land-use information for Tug Fork basin during $1950-1980$

\begin{tabular}{|c|c|c|c|c|c|c|}
\hline \multirow{2}{*}{$\begin{array}{l}\text { Sub- } \\
\text { area } \\
\text { No. }\end{array}$} & \multirow{2}{*}{$\begin{array}{c}\text { Acreage } \\
\text { of } \\
\text { Subarea }\end{array}$} & \multirow{2}{*}{$\begin{array}{l}\text { Percent } \\
\text { of total } \\
\text { area }\end{array}$} & \multicolumn{4}{|c|}{$\begin{array}{c}\text { Acreage of } \\
\text { land-use category }\end{array}$} \\
\hline & & & 1950 & 1960 & 1976 & 1980 \\
\hline & \multicolumn{6}{|c|}{ 1. Urban } \\
\hline 1 & 46912 & 4.86 & 153.1 & 164.0 & 259.7 & 259.7 \\
\hline 2 & 54912 & 5.69 & 206.2 & 247.6 & 231.2 & 243.3 \\
\hline 3 & 44172 & 4.58 & 11.1 & 44.6 & 36.6 & 36.6 \\
\hline 4 & 39062 & 4.05 & 63.2 & 83.3 & 85.0 & 85.0 \\
\hline 5 & 18560 & 1.92 & 74.2 & 162.2 & 158.8 & 158.8 \\
\hline 6 & 42206 & 4.38 & 31.1 & 31.1 & 95.1 & 95.1 \\
\hline 7 & 29084 & 3.02 & 17.3 & 17.3 & 12.6 & 12.6 \\
\hline 8 & 38766 & 4.02 & 111.1 & 111.1 & 145.0 & 172.0 \\
\hline $8 a$ & 1916 & .20 & 91.4 & 91.4 & 137.3 & 137.3 \\
\hline 9 & 7610 & .79 & 9.3 & 9.3 & 24.6 & 24.6 \\
\hline 10 & 16361 & 1.70 & 0.0 & 0.0 & 0.0 & 0.0 \\
\hline 11 & 19840 & 2.06 & 0.0 & 0.0 & 0.0 & 0.0 \\
\hline 12 & 29612 & 3.07 & 0.0 & 0.0 & 0.0 & 0.0 \\
\hline 13 & 25750 & 2.67 & 0.0 & 0.0 & 0.0 & 0.0 \\
\hline 14 & 28202 & 2.92 & 0.0 & 0.0 & 0.0 & 0.0 \\
\hline 15 & 17587 & 1.82 & 0.0 & 0.0 & 0.0 & 0.0 \\
\hline 16 & 65075 & 6.75 & 189.5 & 186.5 & 187.4 & 183.4 \\
\hline 17 & 21120 & 2.19 & 32.0 & 32.0 & 59.5 & 59.5 \\
\hline 18 & 12452 & 1.29 & 0.0 & 0.0 & 0.0 & 0.0 \\
\hline 19 & 39841 & 4.13 & 260.7 & 260.7 & 285.4 & 279.8 \\
\hline 20 & 36898 & 3.83 & 17.6 & 46.9 & 47.6 & 47.6 \\
\hline 21 & 23198 & 2.41 & 0.0 & 0.0 & 0.0 & 0.0 \\
\hline 22 & 63454 & 6.58 & 337.0 & 267.4 & 327.9 & 327.9 \\
\hline 23 & 37730 & 3.91 & 0.0 & 0.0 & 0.0 & 0.0 \\
\hline 24 & 53933 & 5.59 & 0.0 & 0.0 & 7.2 & 7.2 \\
\hline 25 & 57003 & 5.91 & 115.9 & 115.9 & 133.8 & 174.3 \\
\hline 26 & 40384 & 4.19 & 35.4 & 40.9 & 64.1 & 119.3 \\
\hline 27 & 18371 & 1.90 & 0.0 & 0.0 & 0.0 & 0.0 \\
\hline 28 & 34469 & 3.57 & 0.0 & 0.0 & 0.0 & 0.0 \\
\hline Total & 964480 & 100.00 & 1756.1 & 1912.2 & 2298.8 & 2424.0 \\
\hline
\end{tabular}


Table 6.--Continued

2. Active mining

\begin{tabular}{rrrrrrr}
1 & 46912 & 4.86 & 47.7 & 645.0 & 1586.3 & 593.7 \\
2 & 54912 & 5.69 & 73.9 & 137.5 & 939.3 & 323.0 \\
3 & 44172 & 4.58 & 0.0 & 589.0 & 401.5 & 385.0 \\
4 & 39062 & 4.05 & 54.3 & 195.0 & 182.1 & 0.0 \\
5 & 18560 & 1.92 & 13.0 & 13.0 & 45.0 & 33.3 \\
6 & 42206 & 4.38 & 8.8 & 8.8 & 17.0 & 29.4 \\
7 & 29084 & 3.02 & 0.0 & 39.6 & 14.7 & 18.7 \\
8 & 38766 & 4.02 & 40.1 & 205.8 & 113.6 & 79.6 \\
$8 a$ & 1916 & .20 & 0.0 & 0.0 & 42.7 & 29.7 \\
9 & 7610 & .79 & 0.0 & 0.0 & 0.0 & 0.0 \\
10 & 16361 & 1.70 & 0.0 & 12.6 & 5.0 & 0.0 \\
11 & 19840 & 2.06 & 0.0 & 21.1 & 21.1 & 0.0 \\
12 & 29612 & 3.07 & 216.3 & 368.7 & 638.1 & 372.0 \\
13 & 25750 & 2.67 & 20.4 & 117.8 & 294.0 & 113.9 \\
14 & 28202 & 2.92 & 0.0 & 33.1 & 306.5 & 165.1 \\
15 & 17587 & 1.82 & 66.9 & 185.5 & 506.6 & 448.3 \\
16 & 65075 & 6.75 & 1154.2 & 1312.8 & 1222.0 & 784.9 \\
17 & 21120 & 2.19 & 7.6 & 7.9 & 467.6 & 304.0 \\
18 & 12452 & 1.29 & 20.3 & 20.3 & 0.0 & 2.2 \\
19 & 39841 & 4.13 & 185.5 & 527.0 & 224.1 & 137.9 \\
20 & 36898 & 3.83 & 0.0 & 132.1 & 39.5 & 77.2 \\
21 & 23198 & 2.41 & 0.0 & 0.0 & 53.8 & 35.4 \\
22 & 63454 & 6.58 & 72.9 & 108.3 & 220.5 & 374.1 \\
23 & 37730 & 3.91 & 14.7 & 41.9 & 512.0 & 335.5 \\
24 & 53933 & 5.59 & 7.0 & 9.7 & 1656.1 & 2146.7 \\
25 & 57003 & 5.91 & 0.0 & 0.0 & 39.8 & 94.2 \\
26 & 40384 & 4.19 & 0.0 & 0.0 & 1259.4 & 1487.8 \\
27 & 18371 & 1.90 & 9.6 & 30.7 & 574.8 & 205.1 \\
28 & 34469 & 3.57 & 0.0 & 0.0 & 489.7 & 290.1 \\
\hline Total & & & & 0.0 & 0.0 & \\
& 964480 & 100.00 & 2013.2 & 4763.7 & 11872.8 & 8866.8
\end{tabular}


Table 6.--Continued

3. Inactive mining

\begin{tabular}{rrrrrrr}
1 & 46912 & 4.86 & 0.0 & 0.0 & 1248.5 & 307.6 \\
2 & 54912 & 5.69 & 0.0 & 0.0 & 1443.4 & 355.5 \\
3 & 44172 & 4.58 & 0.0 & 26.4 & 407.6 & 244.4 \\
4 & 39062 & 4.05 & 0.0 & 0.0 & 116.3 & 113.4 \\
5 & 18560 & 1.92 & 0.0 & 0.0 & 116.7 & 116.7 \\
6 & 42206 & 4.38 & 0.0 & 0.0 & 333.2 & 115.1 \\
7 & 29084 & 3.02 & 0.0 & 0.0 & 20.8 & 20.8 \\
8 & 38766 & 4.02 & 0.0 & 0.0 & 144.6 & 128.7 \\
$8 \mathrm{a}$ & 1916 & .20 & 0.0 & 0.0 & 58.0 & 3.8 \\
9 & 7610 & .79 & 0.0 & 0.0 & 4.4 & 4.4 \\
10 & 16361 & 1.70 & 0.0 & 0.0 & 45.1 & 5.0 \\
11 & 19840 & 2.06 & 0.0 & 0.0 & 86.3 & 0.0 \\
12 & 29612 & 3.07 & 0.0 & 0.0 & 289.2 & 477.3 \\
13 & 25750 & 2.67 & 0.0 & 0.0 & 1065.5 & 730.1 \\
14 & 28202 & 2.92 & 0.0 & 0.0 & 739.6 & 465.2 \\
15 & 17587 & 1.82 & 0.0 & 0.0 & 1119.3 & 1431.2 \\
16 & 65075 & 6.75 & 0.0 & 127.0 & 1842.8 & 1576.2 \\
17 & 21120 & 2.19 & 0.0 & 0.0 & 279.9 & 596.7 \\
18 & 12452 & 1.29 & 0.0 & 0.0 & 521.5 & 470.7 \\
19 & 39841 & 4.13 & 0.0 & 0.0 & 0.0 & 366.6 \\
20 & 36898 & 3.83 & 0.0 & 0.0 & 406.7 & 67.9 \\
21 & 23198 & 2.41 & 0.0 & 0.0 & 56.9 & 62.6 \\
22 & 63454 & 6.58 & 0.0 & 13.7 & 172.5 & 210.1 \\
23 & 37730 & 3.91 & 0.0 & 0.0 & 698.1 & 1001.3 \\
24 & 53933 & 5.59 & 0.0 & 0.0 & 626.8 & 322.2 \\
25 & 57003 & 5.91 & 0.0 & 0.0 & 28.0 & 37.4 \\
26 & 40384 & 4.19 & 0.0 & 0.0 & 662.8 & 518.3 \\
27 & 18371 & 1.90 & 0.0 & 0.0 & 135.2 & 117.6 \\
28 & 34469 & 3.57 & $\underline{0.0}$ & $\underline{0.0}$ & 356.0 & 262.6 \\
\hline Total & & & & & & \\
& 964480 & 100.00 & 0.0 & 167.1 & 13025.7 & 10129.4
\end{tabular}


Table 6.--Continued

4. Reclaimed

\begin{tabular}{rrrrrrr}
1 & 46912 & 4.86 & 0.0 & 0.0 & 2380.1 & 4653.6 \\
2 & 54912 & 5.69 & 0.0 & 0.0 & 2897.4 & 5043.1 \\
3 & 44172 & 4.58 & 0.0 & 0.0 & 3052.2 & 3663.5 \\
4 & 39062 & 4.05 & 0.0 & 0.0 & 571.0 & 791.2 \\
5 & 18560 & 1.92 & 0.0 & 0.0 & 175.4 & 190.2 \\
6 & 42206 & 4.38 & 0.0 & 0.0 & 661.1 & 899.3 \\
7 & 29084 & 3.02 & 0.0 & 0.0 & 230.6 & 276.3 \\
8 & 38766 & 4.02 & 0.0 & 0.0 & 879.3 & 1004.5 \\
$8 a$ & 1916 & .20 & 0.0 & 0.0 & 0.0 & 117.2 \\
9 & 7610 & .79 & 0.0 & 0.0 & 0.0 & 0.0 \\
10 & 16361 & 1.70 & 0.0 & 0.0 & 162.6 & 207.7 \\
11 & 19840 & 2.06 & 0.0 & 0.0 & 19.6 & 127.0 \\
12 & 29612 & 3.07 & 0.0 & 0.0 & 600.3 & 766.9 \\
13 & 25750 & 2.67 & 0.0 & 0.0 & 211.4 & 709.1 \\
14 & 28202 & 2.92 & 0.0 & 0.0 & 334.7 & 655.9 \\
15 & 17587 & 1.82 & 0.0 & 0.0 & 118.6 & 118.6 \\
16 & 65075 & 6.75 & 0.0 & 0.0 & 1908.4 & 3096.6 \\
17 & 21120 & 2.19 & 0.0 & 0.0 & 170.3 & 259.6 \\
18 & 12452 & 1.29 & 0.0 & 0.0 & 53.7 & 237.1 \\
19 & 39841 & 4.13 & 5.4 & 5.4 & 725.3 & 789.7 \\
20 & 36898 & 3.83 & 0.0 & 0.0 & 222.7 & 826.7 \\
21 & 23198 & 2.41 & 0.0 & 0.0 & 332.5 & 385.3 \\
22 & 63454 & 6.58 & 0.0 & 0.0 & 677.9 & 648.5 \\
23 & 37730 & 3.91 & 0.0 & 0.0 & 474.5 & 547.5 \\
24 & 53933 & 5.59 & 0.0 & 0.0 & 670.9 & 2393.6 \\
25 & 57003 & 5.91 & 0.0 & 0.0 & 23.4 & 86.1 \\
26 & 40384 & 4.19 & 0.0 & 0.0 & 800.5 & 2365.1 \\
27 & 18371 & 1.90 & 0.0 & 0.0 & 932.1 & 1548.7 \\
28 & 34469 & 3.57 & 0.0 & 0.0 & 0.0 & 587.3 \\
\hline Total & 964480 & 100.00 & 5.4 & 5.4 & 19286.5 & 32995.9
\end{tabular}


Table 6.--Continued

5. Associated mining

\begin{tabular}{|c|c|c|c|c|c|c|}
\hline 1 & 46912 & 4.86 & 33.2 & 47.6 & 222.8 & 229.1 \\
\hline 2 & 54912 & 5.69 & 0.0 & 25.8 & 193.8 & 193.0 \\
\hline 3 & 44172 & 4.58 & 0.0 & 0.0 & 76.9 & 102.1 \\
\hline 4 & 39062 & 4.05 & 8.5 & 8.5 & 17.8 & 18.0 \\
\hline 5 & 18560 & 1.92 & 0.0 & 0.0 & 63.1 & 63.1 \\
\hline 6 & 42206 & 4.38 & 0.0 & 0.0 & 28.4 & 28.4 \\
\hline 7 & 29084 & 3.02 & 0.0 & 0.0 & 7.4 & 18.8 \\
\hline 8 & 38766 & 4.02 & 0.0 & 0.0 & 29.4 & 69.1 \\
\hline $8 a$ & 1916 & .20 & 0.0 & 0.0 & 0.0 & 0.0 \\
\hline 9 & 7610 & .79 & 0.0 & 0.0 & 0.0 & 0.0 \\
\hline 10 & 16361 & 1.70 & 0.0 & 0.0 & 0.0 & 0.0 \\
\hline 11 & 19840 & 2.06 & 0.0 & 0.0 & 0.0 & 0.0 \\
\hline 12 & 29612 & 3.07 & 0.0 & 0.0 & 0.0 & 0.0 \\
\hline 13 & 25750 & 2.67 & 0.0 & 0.0 & 13.8 & 13.8 \\
\hline 14 & 28202 & 2.92 & 0.0 & 0.0 & 0.0 & 0.0 \\
\hline 15 & 17587 & 1.82 & 0.0 & 0.0 & 0.0 & 0.0 \\
\hline 16 & 65075 & 6.75 & 0.0 & 0.0 & 0.0 & 0.0 \\
\hline 17 & 21120 & 2.19 & 0.0 & 0.0 & 0.0 & 0.0 \\
\hline 18 & 12452 & 1.29 & 0.0 & 0.0 & 132.6 & 0.0 \\
\hline 19 & 39841 & 4.13 & 25.6 & 15.2 & 87.9 & 105.0 \\
\hline 20 & 36898 & 3.83 & 0.0 & 0.0 & 0.0 & 0.0 \\
\hline 21 & 23198 & 2.41 & 5.4 & 5.4 & 10.7 & 10.7 \\
\hline 22 & 63454 & 6.58 & 0.0 & 0.0 & 15.1 & 15.1 \\
\hline 23 & 37730 & 3.91 & 0.0 & 0.0 & 39.7 & 58.0 \\
\hline 24 & 53933 & 5.59 & 0.0 & 0.0 & 51.4 & 36.7 \\
\hline 25 & 57003 & 5.91 & 0.0 & 0.0 & 0.0 & 0.0 \\
\hline 26 & 40384 & 4.19 & 0.0 & 0.0 & 0.0 & 0.0 \\
\hline 27 & 18371 & 1.90 & 0.0 & 0.0 & 0.0 & 29.7 \\
\hline 28 & 34469 & 3.57 & 0.0 & 0.0 & 0.0 & 0.0 \\
\hline al & 964480 & 100.00 & 72.7 & 102.5 & 990.8 & 990.6 \\
\hline
\end{tabular}


Table 6.--Continued

6. Total surface area disturbed by mining (categories $2+3+4+5$ )

\begin{tabular}{|c|c|c|c|c|c|c|}
\hline 1 & 46912 & 4.86 & 80.9 & 692.6 & 5437.7 & 5784.0 \\
\hline 2 & 54912 & 5.69 & 73.9 & 163.3 & 5473.9 & 5914.6 \\
\hline 3 & 44172 & 4.58 & 0.0 & 615.4 & 3938.2 & 4395.0 \\
\hline 4 & 39062 & 4.05 & 62.8 & 203.5 & 887.2 & 922.6 \\
\hline 5 & 18560 & 1.92 & 13.0 & 13.0 & 400.2 & 403.3 \\
\hline 6 & 42206 & 4.38 & 8.8 & 8.8 & 1039.7 & 1072.2 \\
\hline 7 & 29084 & 3.02 & 0.0 & 39.6 & 273.5 & 334.6 \\
\hline 8 & 38766 & 4.02 & 40.1 & 205.8 & 1166.9 & 1281.9 \\
\hline $8 a$ & 1916 & .20 & 0.0 & 0.0 & 100.7 & 150.7 \\
\hline 9 & 7610 & .79 & 0.0 & 0.0 & 4.4 & 4.4 \\
\hline 10 & 16361 & 1.70 & 0.0 & 12.6 & 212.7 & 212.7 \\
\hline 11 & 19840 & 2.06 & 0.0 & 21.1 & 127.0 & 127.0 \\
\hline 12 & 29612 & 3.07 & 216.3 & 368.7 & 1527.6 & 1616.2 \\
\hline 13 & 25750 & 2.67 & 20.4 & 117.8 & 1584.7 & 1566.9 \\
\hline 14 & 28202 & 2.92 & 0.0 & 33.1 & 1380.8 & 1286.2 \\
\hline 15 & 17587 & 1.82 & 66.9 & 185.5 & 1744.5 & 1998.1 \\
\hline 16 & 65075 & 6.75 & 1154.2 & 1439.8 & 4973.2 & 5457.7 \\
\hline 17 & 21120 & 2.19 & 7.6 & 7.9 & 917.8 & 1160.3 \\
\hline 18 & 12452 & 1.29 & 20.3 & 20.3 & 707.8 & 710.0 \\
\hline 19 & 39841 & 4.13 & 216.5 & 547.6 & 1037.3 & 1399.2 \\
\hline 20 & 36898 & 3.83 & 0.0 & 132.1 & 668.9 & 971.8 \\
\hline 21 & 23198 & 2.41 & 5.4 & 5.4 & 453.9 & 494.0 \\
\hline 22 & 63454 & 6.58 & 72.9 & 122.0 & 1086.0 & 1247.8 \\
\hline 23 & 37730 & 3.91 & 14.7 & 41.9 & 1724.3 & 1942.3 \\
\hline 24 & 53933 & 5.59 & 7.0 & 9.7 & 3005.2 & 4899.2 \\
\hline 25 & 57003 & 5.91 & 0.0 & 0.0 & 91.2 & 217.7 \\
\hline 26 & 40384 & 4.19 & 0.0 & 0.0 & 2722.7 & 4371.2 \\
\hline 27 & 18371 & 1.90 & 9.6 & 30.7 & 1642.1 & 1901.1 \\
\hline 28 & 34469 & 3.5 & 0.0 & 0.0 & 845.7 & 1140.0 \\
\hline & 64480 & 00.00 & 2091.3 & 5038.2 & 45175.8 & 52982 \\
\hline
\end{tabular}


Table 6.--Continued

7. Logged areas

\begin{tabular}{ccccccc}
1 & 46912 & 4.86 & 0.0 & 0.0 & 0.0 & 0.0 \\
2 & 54912 & 5.69 & 0.0 & 0.0 & 0.0 & 0.0 \\
3 & 44172 & 4.58 & 0.0 & 0.0 & 0.0 & 0.0 \\
4 & 39062 & 4.05 & 0.0 & 0.0 & 0.0 & 0.0 \\
5 & 18560 & 1.92 & 0.0 & 0.0 & 0.0 & 0.0 \\
6 & 42206 & 4.38 & 0.0 & 0.0 & 0.0 & 0.0 \\
7 & 29084 & 3.02 & 0.0 & 0.0 & 0.0 & 0.0 \\
8 & 38766 & 4.02 & 0.0 & 0.0 & 0.0 & 0.0 \\
$8 a$ & 1916 & .20 & 0.0 & 0.0 & 0.0 & 0.0 \\
9 & 7610 & .79 & 0.0 & 0.0 & 0.0 & 0.0 \\
10 & 16361 & 1.70 & 0.0 & 0.0 & 0.0 & 0.0 \\
11 & 19840 & 2.06 & 0.0 & 0.0 & 0.0 & 0.0 \\
12 & 29612 & 3.07 & 0.0 & 0.0 & 0.0 & 0.0 \\
13 & 25750 & 2.67 & 0.0 & 0.0 & 0.0 & 0.0 \\
14 & 28202 & 2.92 & 0.0 & 0.0 & 0.0 & 0.0 \\
15 & 17587 & 1.82 & 0.0 & 0.0 & 0.0 & 0.0 \\
16 & 65075 & 6.75 & 0.0 & 0.0 & 0.0 & 0.0 \\
17 & 21120 & 2.19 & 0.0 & 0.0 & 0.0 & 0.0 \\
18 & 12452 & 1.29 & 0.0 & 0.0 & 0.0 & 0.0 \\
19 & 39841 & 4.13 & 0.0 & 0.0 & 0.0 & 0.0 \\
20 & 36898 & 3.83 & 0.0 & 0.0 & 0.0 & 0.0 \\
21 & 23198 & 2.41 & 0.0 & 0.0 & 0.0 & 0.0 \\
22 & 63454 & 6.58 & 0.0 & 0.0 & 0.0 & 0.0 \\
23 & 37730 & 3.91 & 0.0 & 0.0 & 0.0 & 0.0 \\
24 & 53933 & 5.59 & 0.0 & 0.0 & 0.0 & 0.0 \\
25 & 57003 & 5.91 & 0.0 & 0.0 & 0.0 & 0.0 \\
26 & 40384 & 4.19 & 0.0 & 0.0 & 0.0 & 0.0 \\
27 & 18371 & 1.90 & 0.0 & 0.0 & 0.0 & 0.0 \\
28 & 34469 & 3.57 & 0.0 & 0.0 & 0.0 & 0.0 \\
\hline Total & 964480 & 100.00 & 0.0 & 0.0 & 0.0 & 0.0
\end{tabular}


Table 6.--Continued

8. Agriculture

\begin{tabular}{rrrrrrr}
1 & 46912 & 4.86 & 858.9 & 825.7 & 384.6 & 396.2 \\
2 & 54912 & 5.69 & 360.9 & 329.9 & 82.9 & 83.5 \\
3 & 44172 & 4.58 & 1852.3 & 1882.3 & 430.2 & 395.6 \\
4 & 39062 & 4.05 & 1228.2 & 1862.0 & 810.4 & 833.3 \\
5 & 18560 & 1.92 & 56.4 & 56.4 & 0.0 & 0.0 \\
6 & 42206 & 4.38 & 576.4 & 576.4 & 81.3 & 81.3 \\
7 & 29084 & 3.02 & 119.6 & 107.3 & 0.0 & 0.0 \\
8 & 38766 & 4.02 & 103.7 & 119.9 & 21.3 & 21.3 \\
$8 \mathrm{a}$ & 1916 & .20 & 14.8 & 14.8 & 14.0 & 0.0 \\
9 & 7610 & .79 & 170.0 & 164.4 & 0.0 & 0.0 \\
10 & 16361 & 1.70 & 247.9 & 247.9 & 11.6 & 11.6 \\
11 & 19840 & 2.06 & 442.8 & 357.4 & 114.2 & 114.2 \\
12 & 29612 & 3.07 & 205.5 & 158.9 & 10.1 & 10.1 \\
13 & 25750 & 2.67 & 380.7 & 371.0 & 27.8 & 27.8 \\
14 & 28202 & 2.92 & 750.1 & 750.1 & 0.0 & 0.0 \\
15 & 17587 & 1.82 & 117.4 & 95.7 & 0.0 & 0.0 \\
16 & 65075 & 6.75 & 299.9 & 313.8 & 0.0 & 0.0 \\
17 & 21120 & 2.19 & 168.5 & 168.5 & 36.0 & 36.0 \\
18 & 12452 & 1.29 & 191.5 & 191.5 & 12.0 & 12.0 \\
19 & 39841 & 4.13 & 779.5 & 749.1 & 17.2 & 17.2 \\
20 & 36898 & 3.83 & 348.2 & 357.4 & 0.0 & 0.0 \\
21 & 23198 & 2.41 & 479.8 & 436.4 & 0.0 & 0.0 \\
22 & 63454 & 6.58 & 616.3 & 461.1 & 7.9 & 70.6 \\
23 & 37730 & 3.91 & 1203.9 & 1279.1 & 257.7 & 258.7 \\
24 & 53933 & 5.59 & 1190.9 & 937.5 & 137.5 & 136.4 \\
25 & 57003 & 5.91 & 967.7 & 835.1 & 214.9 & 207.0 \\
26 & 40384 & 4.19 & 1140.8 & 1207.0 & 0.0 & 308.1 \\
27 & 18371 & 1.90 & 485.0 & 479.7 & 138.3 & 136.9 \\
28 & 34469 & 3.57 & 402.4 & 389.8 & 337.7 & 337.7 \\
\hline Total & 964480 & 100.00 & 15760.0 & 15726.1 & 3147.6 & 3495.5
\end{tabular}


Table 6.--Continued

9. Improved roads

\begin{tabular}{rrrrrrr}
1 & 46912 & 4.86 & 292.0 & 292.0 & 292.0 & 305.7 \\
2 & 54912 & 5.69 & 265.4 & 265.4 & 265.4 & 265.4 \\
3 & 44172 & 4.58 & 225.6 & 225.6 & 225.6 & 225.6 \\
4 & 39062 & 4.05 & 219.1 & 219.1 & 219.1 & 219.1 \\
5 & 18560 & 1.92 & 86.0 & 86.0 & 86.0 & 86.0 \\
6 & 42206 & 4.38 & 129.3 & 129.3 & 129.3 & 129.3 \\
7 & 29084 & 3.02 & 66.6 & 66.6 & 66.6 & 66.6 \\
8 & 38766 & 4.02 & 139.7 & 139.7 & 139.7 & 139.7 \\
$8 \mathrm{a}$ & 1916 & .20 & 6.9 & 6.9 & 6.9 & 6.9 \\
9 & 7610 & .79 & 47.0 & 47.0 & 47.0 & 47.0 \\
10 & 16361 & 1.70 & 70.0 & 70.0 & 70.0 & 70.0 \\
11 & 19840 & 2.06 & 60.1 & 60.1 & 60.1 & 60.1 \\
12 & 29612 & 3.07 & 96.3 & 96.3 & 96.3 & 96.3 \\
13 & 25750 & 2.67 & 93.4 & 93.4 & 93.4 & 93.4 \\
14 & 28202 & 2.92 & 98.4 & 98.4 & 98.4 & 100.5 \\
15 & 17587 & 1.82 & 47.1 & 47.1 & 47.1 & 47.1 \\
16 & 65075 & 6.75 & 194.9 & 194.9 & 194.9 & 194.9 \\
17 & 21120 & 2.19 & 110.3 & 110.3 & 110.3 & 110.3 \\
18 & 12452 & 1.29 & 45.2 & 45.2 & 45.2 & 45.2 \\
19 & 39841 & 4.13 & 248.7 & 248.7 & 248.7 & 249.8 \\
20 & 36898 & 3.83 & 141.1 & 141.1 & 140.0 & 140.0 \\
21 & 23198 & 2.41 & 61.4 & 61.4 & 82.0 & 85.9 \\
22 & 63454 & 6.58 & 269.2 & 269.2 & 275.8 & 283.8 \\
23 & 37730 & 3.91 & 129.9 & 129.9 & 129.9 & 129.9 \\
24 & 53933 & 5.59 & 69.6 & 69.6 & 69.6 & 69.6 \\
25 & 57003 & 5.91 & 243.8 & 243.8 & 245.9 & 245.9 \\
26 & 40384 & 4.19 & 101.6 & 101.6 & 101.6 & 101.6 \\
27 & 18371 & 1.90 & 51.9 & 51.9 & 51.9 & 51.9 \\
28 & 34469 & 3.57 & 131.8 & 131.8 & 135.8 & 135.8 \\
\hline Total & 964480 & 100.00 & 3742.3 & 3742.3 & 3774.5 & 3803.3
\end{tabular}


Table 6.--Continued

\section{Undeveloped roads}

\begin{tabular}{rrrrrrr}
1 & 46912 & 4.86 & 238.4 & 238.4 & 238.4 & 238.4 \\
2 & 54912 & 5.69 & 197.8 & 197.8 & 197.8 & 197.8 \\
3 & 44172 & 4.58 & 118.9 & 118.9 & 118.9 & 118.9 \\
4 & 39062 & 4.05 & 99.2 & 99.2 & 99.2 & 99.2 \\
5 & 18560 & 1.92 & 100.7 & 100.7 & 100.7 & 100.7 \\
6 & 42206 & 4.38 & 288.8 & 288.8 & 288.8 & 288.8 \\
7 & 29084 & 3.02 & 213.0 & 213.0 & 213.0 & 213.0 \\
8 & 38766 & 4.02 & 185.9 & 185.9 & 185.9 & 185.9 \\
$8 \mathrm{a}$ & 1916 & .20 & 9.2 & 9.2 & 9.2 & 9.2 \\
9 & 7610 & .79 & 34.9 & 34.9 & 34.9 & 34.9 \\
10 & 16361 & 1.70 & 76.3 & 76.3 & 76.3 & 76.3 \\
11 & 19840 & 2.06 & 112.0 & 112.0 & 112.0 & 112.0 \\
12 & 29612 & 3.07 & 61.6 & 61.6 & 61.6 & 61.6 \\
13 & 25750 & 2.67 & 100.9 & 100.9 & 100.9 & 100.9 \\
14 & 28202 & 2.92 & 52.2 & 52.2 & 52.2 & 52.2 \\
15 & 17587 & 1.82 & 47.1 & 47.1 & 47.1 & 47.1 \\
16 & 65075 & 6.75 & 196.9 & 196.9 & 196.9 & 196.9 \\
17 & 21120 & 2.19 & 73.0 & 73.0 & 73.0 & 73.0 \\
18 & 12452 & 1.29 & 64.3 & 64.3 & 64.3 & 64.3 \\
19 & 39841 & 4.13 & 180.3 & 180.3 & 180.3 & 180.3 \\
20 & 36898 & 3.83 & 88.6 & 88.6 & 92.4 & 92.4 \\
21 & 23198 & 2.41 & 56.8 & 56.8 & 56.8 & 59.0 \\
22 & 63454 & 6.58 & 171.1 & 171.1 & 171.1 & 172.2 \\
23 & 37730 & 3.91 & 116.9 & 116.9 & 116.9 & 116.9 \\
24 & 53933 & 5.59 & 228.1 & 228.1 & 225.5 & 225.5 \\
25 & 57003 & 5.91 & 195.6 & 195.6 & 195.6 & 195.6 \\
26 & 40384 & 4.19 & 173.5 & 173.5 & 173.5 & 173.5 \\
27 & 18371 & 1.90 & 100.2 & 100.2 & 100.2 & 100.2 \\
28 & 34469 & 3.57 & 167.2 & 167.2 & 167.2 & 168.3 \\
\hline Tota1 & 964480 & 100.00 & 3749.4 & 3749.4 & 3750.6 & 3755.0
\end{tabular}


Table 6.--Continued

\section{Ponds}

\begin{tabular}{rrrrrrr}
1 & 46912 & 4.86 & 9.5 & 9.5 & 23.5 & 17.9 \\
2 & 54912 & 5.69 & 10.6 & 10.6 & 75.8 & 165.6 \\
3 & 44172 & 4.58 & 6.4 & 6.4 & 40.8 & 42.1 \\
4 & 39062 & 4.05 & 16.6 & 16.6 & 16.6 & 16.6 \\
5 & 18560 & 1.92 & 1.0 & 1.0 & 4.3 & 1.0 \\
6 & 42206 & 4.38 & 1.9 & 1.9 & 1.8 & 1.9 \\
7 & 29084 & 3.02 & 5.7 & 5.7 & 5.7 & 5.7 \\
8 & 38766 & 4.02 & 1.9 & 1.9 & 9.8 & 9.8 \\
$8 a$ & 1916 & .20 & 0.1 & 0.1 & 0.5 & 0.5 \\
9 & 7610 & .79 & 0.0 & 0.0 & 0.0 & 0.0 \\
10 & 16361 & 1.70 & 0.0 & 0.0 & 0.0 & 0.0 \\
11 & 19840 & 2.06 & 1.2 & 1.2 & 1.2 & 1.2 \\
12 & 29612 & 3.07 & 3.8 & 2.7 & 3.8 & 3.8 \\
13 & 25750 & 2.67 & 1.2 & 1.2 & 1.2 & 1.2 \\
14 & 28202 & 2.92 & 1.7 & 1.7 & 1.7 & 1.7 \\
15 & 17587 & 1.82 & 2.4 & 2.4 & 2.4 & 2.4 \\
16 & 65075 & 6.75 & 6.1 & 6.1 & 9.0 & 6.1 \\
17 & 21120 & 2.19 & 18.6 & 18.6 & 18.6 & 18.6 \\
18 & 12452 & 1.29 & 0.9 & 0.9 & 0.9 & 0.9 \\
19 & 39841 & 4.13 & 4.5 & 4.9 & 16.7 & 16.7 \\
20 & 36898 & 3.83 & 6.4 & 6.4 & 6.4 & 6.4 \\
21 & 23198 & 2.41 & 0.0 & 0.0 & 0.0 & 0.0 \\
22 & 63454 & 6.58 & 24.8 & 24.8 & 24.8 & 24.8 \\
23 & 37730 & 3.91 & 6.3 & 6.3 & 6.3 & 6.3 \\
24 & 53933 & 5.59 & 7.6 & 7.6 & 20.6 & 27.2 \\
25 & 57003 & 5.91 & 1.5 & 1.5 & 1.5 & 1.5 \\
26 & 40384 & 4.19 & 12.6 & 12.6 & 37.2 & 110.4 \\
27 & 18371 & 1.90 & 0.0 & 6.6 & 6.6 & 9.8 \\
28 & 34469 & 3.57 & 5.1 & 5.1 & 5.1 & 5.1 \\
\hline Total & 964480 & 100.00 & 158.4 & 164.3 & 342.8 & 505.2
\end{tabular}


12. Undisturbed

\begin{tabular}{|c|c|c|c|c|c|c|}
\hline 1 & 46912 & 4.86 & 45279.2 & 44689.8 & 40276.1 & 39910.1 \\
\hline 2 & 54912 & 5.69 & 53797.2 & 53697.4 & 48585.0 & 48041.8 \\
\hline 3 & 44172 & 4.58 & 41957.7 & 41278.8 & 39381.7 & 38958.2 \\
\hline 4 & 39062 & 4.05 & 37372.9 & 36577.8 & 36944.5 & 36886.2 \\
\hline 5 & 18560 & 1.92 & 18228.7 & 18140.7 & 17810.0 & 17810.2 \\
\hline 6 & 42206 & 4.38 & 41169.7 & 41169.7 & 40570.0 & 40537.4 \\
\hline 7 & 29084 & 3.02 & 28661.8 & 28634.5 & 28512.6 & 28451.5 \\
\hline 8 & 38766 & 4.02 & 38183.6 & 38001.7 & 37097.4 & 36955.4 \\
\hline $8 a$ & 1916 & .20 & 1793.6 & 1793.6 & 1647.4 & 1611.4 \\
\hline 9 & 7610 & .79 & 7348.8 & 7354.4 & 7499.1 & 7499.1 \\
\hline 10 & 16361 & 1.70 & 15966.8 & 15954.2 & 15990.4 & 15990.4 \\
\hline 11 & 19840 & 2.06 & 19223.9 & 19288.2 & 19425.5 & 19425.5 \\
\hline 12 & 29612 & 3.07 & 29028.5 & 28923.8 & 27912.6 & 27824.0 \\
\hline 13 & 25750 & 2.67 & 25153.4 & 25065.7 & 23942.0 & 23959.8 \\
\hline 14 & 28202 & 2.92 & 27299.6 & 27266.5 & 26668.9 & 26761.4 \\
\hline 15 & 17587 & 1.82 & 17306.1 & 17209.2 & 15745.9 & 15492.3 \\
\hline 16 & 65075 & 6.75 & 63033.5 & 62737.0 & 59513.6 & 59036.0 \\
\hline 17 & 21120 & 2.19 & 20710.0 & 20709.7 & 19904.8 & 19662.3 \\
\hline 18 & 12452 & 1.29 & 12129.8 & 12129.8 & 11621.8 & 11619.6 \\
\hline 19 & 39841 & 4.13 & 38150.8 & 37849.7 & 38055.4 & 37698.0 \\
\hline 20 & 36898 & 3.83 & 36296.1 & 36125.5 & 35942.7 & 35639.8 \\
\hline 21 & 23198 & 2.41 & 22594.6 & 22638.0 & 22605.3 & 22559.1 \\
\hline 22 & 63454 & 6.58 & 61962.7 & 62138.4 & 61550.5 & 61326.9 \\
\hline 23 & 37730 & 3.91 & 36258.3 & 36155.9 & 35494.9 & 35275.9 \\
\hline 24 & 53933 & 5.59 & 52429.8 & 52680.5 & 50467.4 & 48567.9 \\
\hline 25 & 57003 & 5.91 & 55478.5 & 55611.1 & 56120.1 & 55961.0 \\
\hline 26 & 40384 & 4.19 & 38920.1 & 38848.4 & 37284.9 & 35199.9 \\
\hline 27 & 18371 & 1.90 & 17724.3 & 17701.9 & 16431.9 & 16171.1 \\
\hline 28 & 34469 & 3.57 & 33762.5 & 33775.1 & 32977.5 & 32682.1 \\
\hline Total & 964480 & 100.00 & 937222.5 & 934147.0 & 905989.9 & 897514.3 \\
\hline
\end{tabular}




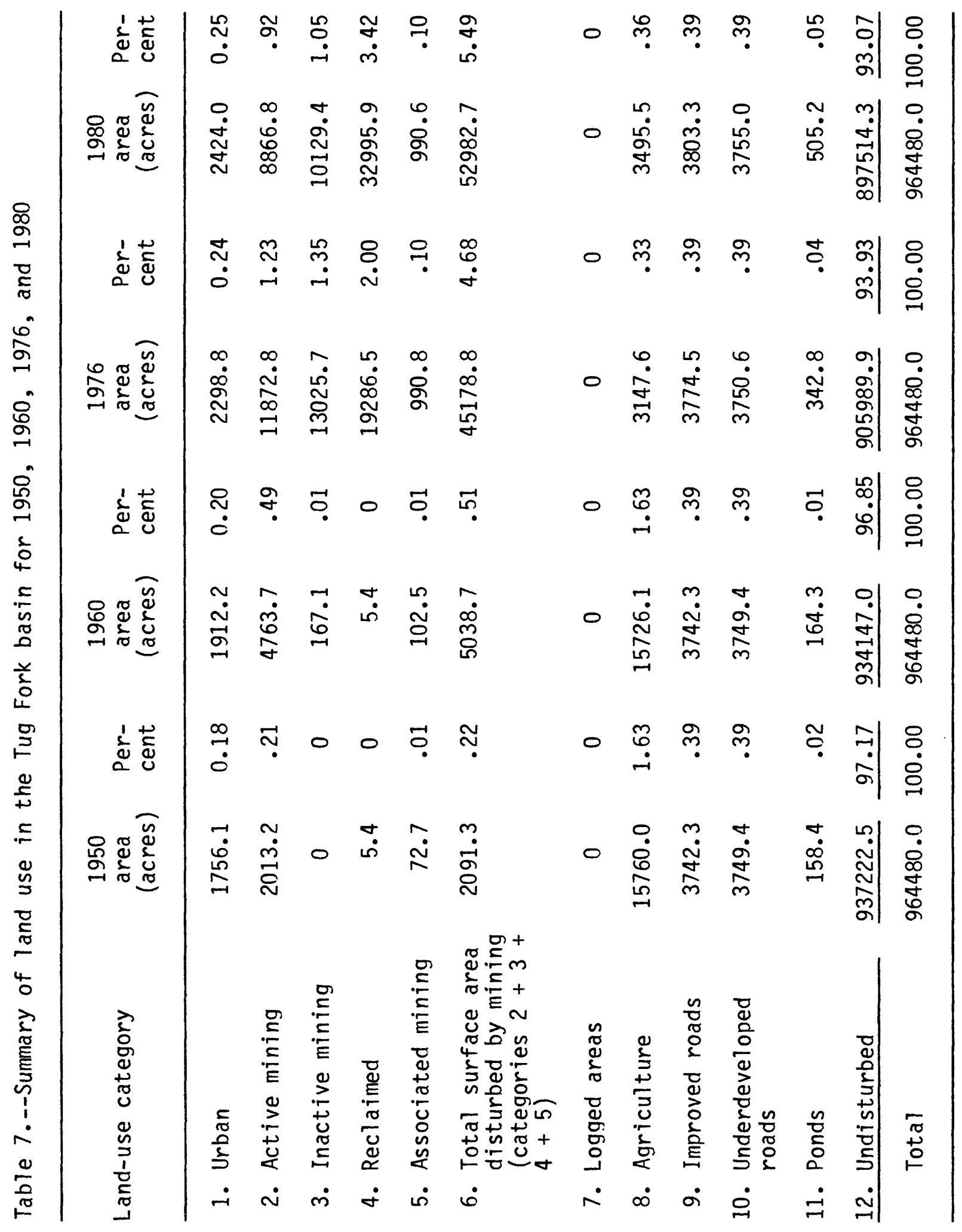



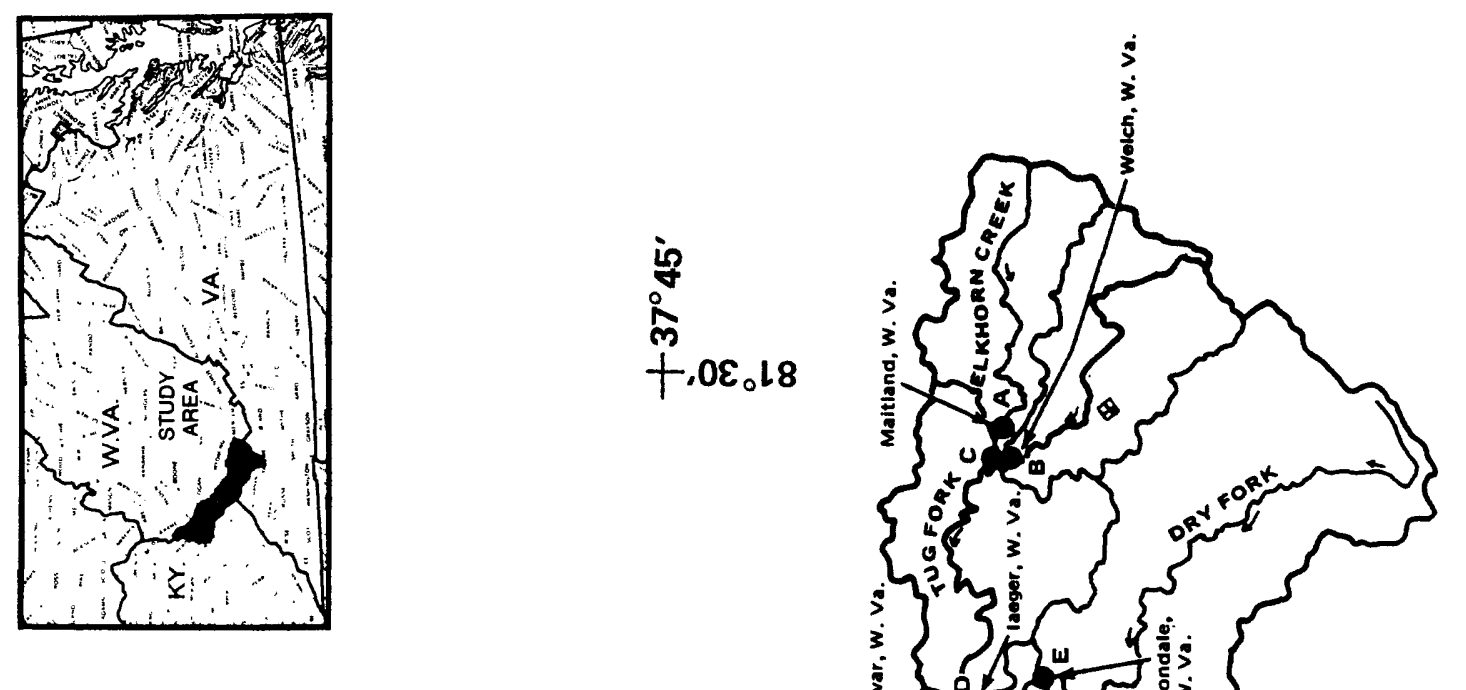

ช્త

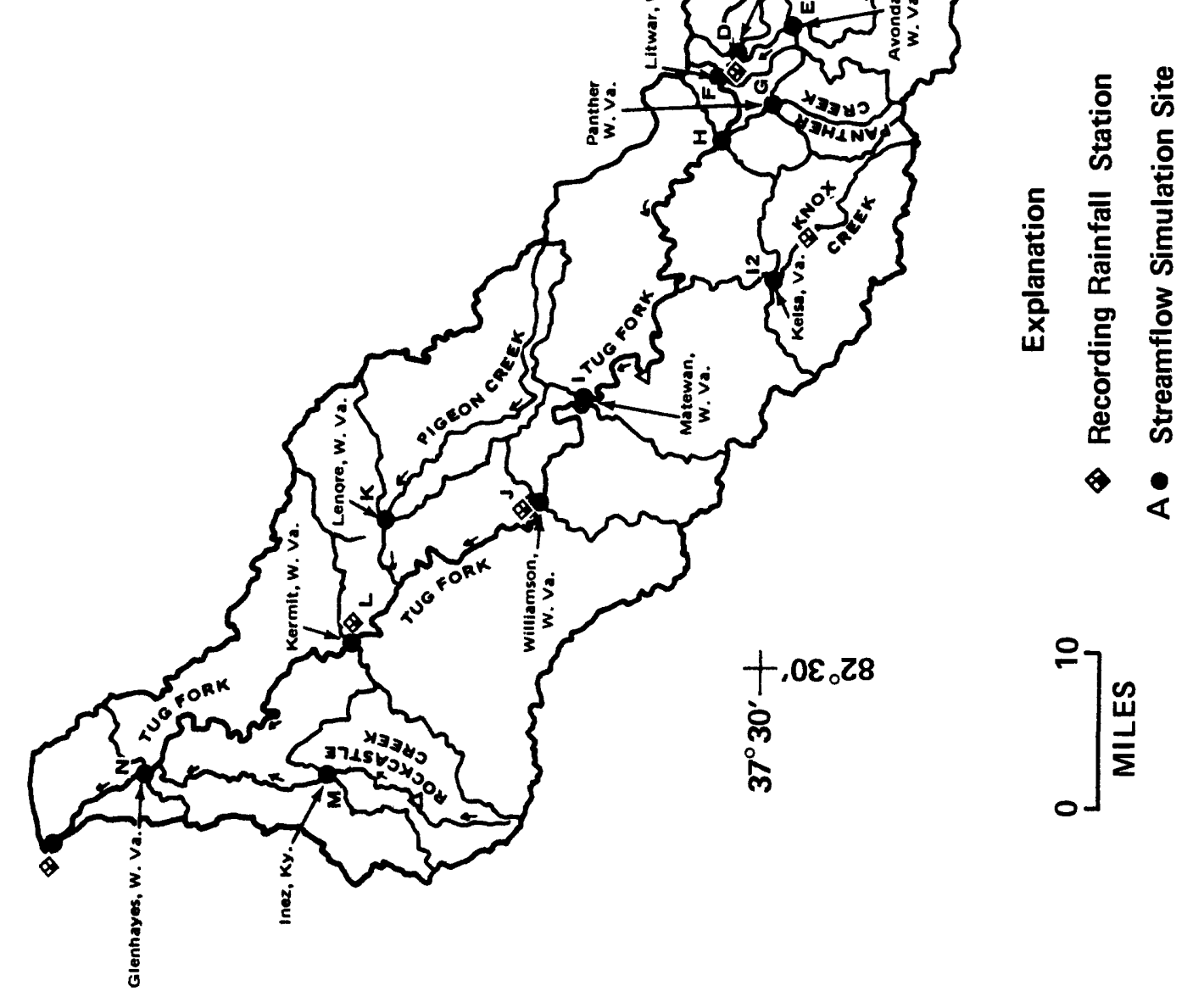


Initial values of model parameters chosen for calibration were based upon knowledge of the watershed surface and soil characteristics, land use, and results of similar PRMS applications in other watersheds. Calibration involves changing selected model parameters to obtain a "best-fit" of the model output to observed data.

For this study, the "best-fit" was based primarily on minimization of a least squares objective function that is inherently biased towards high streamflow

$$
O F=\sum_{i=1}^{n}\left(0_{i}-S_{i}\right)^{2}
$$

where

$0_{i}=$ observed discharge, in cubic foot per second;

$S_{i}=$ simulated discharge, in cubic foot per second; and

$n=$ number of days.

Since the purpose of this study was to evaluate the effects of surface mining on flood peaks, visual inspection was also used to compare observed and computed peak annual flows. In addition an attempt was made to establish good agreement between annual runoff volumes.

The entire basin model was calibrated for both land-use conditions (1980 and 1950) by starting at the most upstream site where streamflow data were available and proceeding downstream. The derived model parameters for the upstream catchments were not adjusted any further as the calibration proceeded downstream. That is, only those model parameters assigned to intervening contributing areas were adjusted to calibrate the model at downstream sites. Tributary sites with measured streamflow data were calibrated independently and incorporated in the entire basin model at their confluence with the Tug Fork.

Good fits obtained during model calibration do not necessarily guarantee good prediction ability. Parameters may have been adjusted to produce accurate simulations only for the time series used in the calibration process. Effective testing of the calibrated model using additional observed time-series data will serve to verify the model for accuracy. For proper calibration and verification, an extensive period of observed data that covers wet, dry, and average periods under static land-use conditions is required. Perhaps 5 to 8 years for both calibration and verification purposes would be a sufficient sample to reduce the effect of errors in observed rainfall and runoff data on the adjusted model parameter values. Detailed model-verification analyses were only possible at three stations where long-term records were available. Limited model verification at the other gaging stations were performed when data were available. 
Calibration and verification of PRMS for 1980 land-use conditions was done using observed daily streamflow data from water years 1977 through 1980. The model was initialized with 1977 water year data, calibrated with 1978 and 1979 data, and verified with 1980 data. Eleven gaging stations were used to some degree in these analyses. Five stations were in operation during the entire period (1977 to 1980): 03213000 Tug Fork at Litwar, W. Va.; 03213500 Panther Creek near Panther, W. Va.; 03213700 Tug Fork at Williamson, W. Va.; 03214000 Tug Fork near Kermit, W. Va.; and 03214900 Tug Fork at Glenhayes, W. Va. Four additional stations were in operation during the last 2 water years 1979 and 1980: 03212700 Elkhorn Creek at Maitland, W. Va.; 03212600 Tug Fork at Welch, W. Va.; 03212985 Dry Fork at Avondale, W. Va.; and 03213800 Pigeon Creek near Lenore, W. Va. The two remaining gages, 03213590 Knox Creek near Kelsa, Va., and 03214700 Rockcastle Creek near Inez, Ky., were only in operation during the 1980 water year for approximately 6 and 10 months, respectively.

Land-use change is a dynamic process. Land disturbed by surface mining may be sporadic or steady in time. To better model the effects of surface-mining activities on flood hydrology, detailed data should be collected to define the time-series of 1 and-use changes. These data may be available from a schedule of the mining activities or by field observation. In this study these data were not available on a year by year basis. Therefore, land-use changes were assumed to be static during the 4-year period. Definition of the land use in the model was taken as the average of the 1976 and 1980 conditions shown in table 6 .

Model parameters fall into one of two categories. Those that have physical significance and can be readily measured such as slope, elevation and drainage area, and those that do not have physical interpretations and whose values are more difficult to determine. Usually, those parameters for which little information may be available are the ones that are adjusted during calibration. The guidance for adjusting these parameters is influenced by previous experience and available literature information on the parameters. In addition, sensitivity analyses can be performed during model calibration to determine the more sensitive parameters.

Sensitivity analyses were performed on nine model parameters in this study. Results from these analyses were used for three purposes. First, the results showed which parameters were the most sensitive to adjustment. The most sensitive parameters were subsequently adjusted during calibration. Second, the sensitivity analyses showed which parameters are highly correlated with each other and therefore should not be adjusted together. Last, the results of the sensitivity analyses showed which days or periods of record would strongly influence the automatic optimization of those parameters. Detailed investigation was made of the identified periods to assure proper model computations and to further assure realistic input data, especially rainfall. Because of the obvious non-representative rainfall patterns that were identified at times, automatic optimization was used cautiously. 
There were three categories of model parameters. Some model parameters such as potential shortwave radiation were assigned equivalent values throughout the basin. Other parameters were assigned values dependent upon which subwatershed was being modeled, while some parameters were related to individual HRUs. Appendix A lists model parameter information for each category. Included are the model parameter names, their definitions, and values used during model calibration. Table 8 lists selected measured and assigned basin characteristics that were used to differentiate between parts of the basin disturbed by mining and those that have not been disturbed. The flatter slopes and bare cover assigned to mined areas represent those that have been most disturbed. Reclaimed areas were defined as having a cover of grasses that influences precipitation interception storage, infiltration, and resulting surface runoff. Last, the areas classified as other were assigned a vegetation cover and surface slope most closely related to actual basin conditions. These same concepts were used to describe landuse declared as mined, reclaimed, and other for the earlier 1950 period. The only difference, however, were the areas, in acres, actually disturbed by surface mining in 1950 and 1980.

There were seven model parameters that were adjusted during calibration for the 1980 land-use condition. The final values (1 isted in Table 8) for these parameters were arrived at through a combination of manual adjustment and limited automated optimization. Parameters that were adjusted in the model were those that influenced surface runoff (empirical coefficients $S C N$ and $S C 1$ ), available moisture storage in the soil (SMAX), percolation of subsurface water (SEP), and coefficients that control the timing and amount of subsurface and ground-water contributions to streamflow (RCF, RCP, and $R(B)$. Data were not available to assign values for the seven model parameters by individual HRU and, therefore, for this study, each parameter was assigned the same value within a subwatershed, regardless of designated land use. Additional data are currently being collected by the Geological Survey to better determine values for SCN, SCl, SMAX, RCF, RCP, RCB, and SEP for surface-mined and reclaimed areas.

Figure 9 shows an example of the fit obtained between observed and model computed discharge hydrographs for the Tug Fork at Litwar, W. Va., for water years 1979 and 1980. Appendix B shows modelcomputed discharge hydrographs for all 4 water years at each of the 11 gaging stations in the basin. Observed data (when available) are also plotted.

\section{Land-Use Condition}

Calibration and verification of PRMS for 1950 land-use conditions were attempted using data available from water years 1951 through 1954. Only three gaging stations were in operation during this period: 03213000 Tug Fork at Litwar, W. Va.; 03213500 Panther Creek near Panther, W. Va.; and 03214000 Tug Fork near Kermit, $W$. Va. Again, as with the 1980 application, the first year of observed data was used to initialize the model, the second and third years for calibration, and the last for verification. 
Table 8.--Selected measured and assigned basin characteristics for the 19801 and-use condition

\begin{tabular}{|c|c|c|c|c|c|c|}
\hline $\begin{array}{l}\text { Reference } \\
\text { point } \\
\text { (see } \\
\text { table 1) }\end{array}$ & $\begin{array}{c}\text { Hydrologic } \\
\text { Response } \\
\text { Unit }\end{array}$ & $\begin{array}{l}\text { Area } \\
\text { (acres) }\end{array}$ & Land use & $\begin{array}{l}\text { Mean } \\
\text { eleva- } \\
\text { tion } \\
(\mathrm{ft})\end{array}$ & $\begin{array}{c}\text { Average } \\
\text { overland } \\
\text { slope } \\
(\mathrm{ft} / \mathrm{ft})\end{array}$ & Cover \\
\hline \multirow[t]{3}{*}{$A$} & 1 & 2091 & Mined & 2380 & 0.0010 & Bare \\
\hline & 2 & 3517 & Reclaimed & 2380 & .0010 & Grasses \\
\hline & 3 & 41860 & Other & 2380 & .1647 & Trees \\
\hline \multirow[t]{3}{*}{ B } & 4 & 1723 & Mined & 2100 & .0010 & Bare \\
\hline & 5 & 3970 & Reclaimed & 2100 & .0010 & Grasses \\
\hline & 6 & 50062 & Other & 2100 & .1859 & Trees \\
\hline \multirow[t]{3}{*}{ C } & 7 & 67 & Mined & 1700 & .0010 & Bare \\
\hline & 8 & 59 & Reclaimed & 1700 & .0010 & Grasses \\
\hline & 9 & 1871 & Other & 1700 & .3035 & Trees \\
\hline \multirow[t]{3}{*}{ D } & 10 & 334 & Mined & 1600 & .0010 & Bare \\
\hline & 11 & 1195 & Reclaimed & 1600 & .0010 & Grasses \\
\hline & 12 & 67193 & Other & 1600 & .1627 & Trees \\
\hline \multirow[t]{3}{*}{$E$} & 13 & 1527 & Mined & 2000 & .0010 & Bare \\
\hline & 14 & 5002 & Reclaimed & 2000 & .0010 & Grasses \\
\hline & 15 & 139453 & Other & 2000 & .1704 & Trees \\
\hline \multirow[t]{2}{*}{$\mathrm{F}$} & 16 & 4 & Mined & 1525 & .0010 & Bare \\
\hline & 17 & 7659 & Other & 1525 & .1181 & Trees \\
\hline \multirow[t]{3}{*}{ G } & 18 & 54 & Mined & 1550 & .0010 & Bare \\
\hline & 19 & 73 & Reclaimed & 1550 & .0010 & Grasses \\
\hline & 20 & 19887 & Other & 1550 & .1331 & Trees \\
\hline \multirow[t]{3}{*}{$H$} & 21 & 27 & Mined & 1500 & .0010 & Bare \\
\hline & 22 & 185 & Reclaimed & 1500 & .0010 & Grasses \\
\hline & 23 & 16463 & Other & 1500 & .1394 & Trees \\
\hline \multirow[t]{3}{*}{ I2 } & 24 & 1954 & Mined & 1500 & .0010 & Bare \\
\hline & 25 & 955 & Reclaimed & 1500 & .0010 & Grasses \\
\hline & 26 & 51753 & Other & 1500 & .1674 & Trees \\
\hline \multirow[t]{3}{*}{ I } & 27 & 6741 & Mined & 1500 & .0010 & Bare \\
\hline & 28 & 3665 & Reclaimed & 1500 & .0010 & Grasses \\
\hline & 29 & 136780 & Other & 1500 & .1410 & Trees \\
\hline \multirow[t]{3}{*}{ J } & 30 & 460 & Mined & 1200 & .0010 & Bare \\
\hline & 31 & 758 & Reclaimed & 1200 & .0010 & Grasses \\
\hline & 32 & 39282 & Other & 1200 & .1855 & Trees \\
\hline \multirow[t]{3}{*}{$k$} & 33 & 411 & Mined & 1350 & .0010 & Bare \\
\hline & 34 & 884 & Reclaimed & 1350 & .0010 & Grasses \\
\hline & 35 & 59622 & Other & 1350 & .1677 & Trees \\
\hline \multirow[t]{3}{*}{$L$} & 36 & 1826 & Mined & 1050 & .0010 & Bare \\
\hline & 37 & 1174 & Reclaimed & 1050 & .0010 & Grasses \\
\hline & 38 & 99843 & Other & 1050 & .1846 & Trees \\
\hline \multirow[t]{3}{*}{$M$} & 39 & 1965 & Mined & 950 & .0010 & Bare \\
\hline & 40 & 1583 & Reclaimed & 950 & .0010 & Grasses \\
\hline & 41 & 37196 & Other & 950 & .1401 & Trees \\
\hline \multirow[t]{3}{*}{ N } & 42 & 3699 & Mined & 850 & .0010 & Bare \\
\hline & 43 & 3121 & Reclaimed & 850 & .0010 & Grasses \\
\hline & 44 & 158340 & Other & 850 & .1331 & Trees \\
\hline
\end{tabular}




\begin{tabular}{ccccccc}
\hline $\begin{array}{l}\text { Reference } \\
\text { point } \\
\text { (see } \\
\text { table 1) }\end{array}$ & $\begin{array}{c}\text { HRUs } \\
\text { added }\end{array}$ & $\begin{array}{c}\text { Empirical } \\
\text { coefficients }\end{array}$ & $\begin{array}{l}\text { SMAX } \\
\text { (in.) }\end{array}$ & $\begin{array}{c}\text { Subsurface } \\
\text { coefficients }\end{array}$ & $\begin{array}{c}\text { SEP } \\
\text { (in./d) }\end{array}$ & $\begin{array}{c}\text { Ground-water } \\
\text { coefficient }\end{array}$ \\
SCN SCl & SCN & RCF & RCP & RCB
\end{tabular}

\begin{tabular}{|c|c|c|c|c|c|c|c|c|}
\hline \multirow[t]{2}{*}{ A } & 1 & 0.0011 & 0.3428 & 3.970 & 0.1000 & 0.2000 & 0.450 & 0.0372 \\
\hline & $\begin{array}{l}2 \\
3\end{array}$ & $\begin{array}{l}.0011 \\
.0011\end{array}$ & $\begin{array}{r}.3428 \\
.3428\end{array}$ & $\begin{array}{l}3.970 \\
3.970\end{array}$ & $\begin{array}{r}.1000 \\
.1000\end{array}$ & $\begin{array}{l}.2000 \\
.2000\end{array}$ & $\begin{array}{l}.450 \\
.450\end{array}$ & $\begin{array}{l}.0372 \\
.0372\end{array}$ \\
\hline \multirow[t]{2}{*}{$B$} & $\begin{array}{l}4 \\
5\end{array}$ & $\begin{array}{l}.0009 \\
.0009\end{array}$ & $\begin{array}{l}.4000 \\
.4000\end{array}$ & $\begin{array}{l}4.916 \\
4.916\end{array}$ & $\begin{array}{r}.1500 \\
.1500\end{array}$ & $\begin{array}{l}.2000 \\
.2000\end{array}$ & $\begin{array}{r}.129 \\
.129\end{array}$ & $\begin{array}{l}.0178 \\
.0178\end{array}$ \\
\hline & 6 & .0009 & .4000 & 4.916 & .1500 & .2000 & .129 & .0178 \\
\hline \multirow[t]{3}{*}{ C } & 7 & .0009 & .4000 & 4.795 & .1566 & .2000 & .125 & .0099 \\
\hline & 8 & .0009 & .4000 & 4.795 & .1566 & .2000 & .125 & .0099 \\
\hline & 9 & .0009 & .4000 & 4.795 & .1566 & .2000 & .125 & .0099 \\
\hline \multirow[t]{3}{*}{ D } & 10 & .0009 & .4000 & 4.795 & .1566 & .2000 & .125 & .0067 \\
\hline & 11 & .0009 & .4000 & 4.795 & .1566 & .2000 & .125 & .0067 \\
\hline & 12 & .0009 & .4000 & 4.795 & .1566 & .2000 & .125 & .0067 \\
\hline \multirow[t]{3}{*}{$E$} & 13 & .0009 & .4000 & 4.716 & .1651 & .2000 & .125 & .0099 \\
\hline & 14 & .0009 & .4000 & 4.716 & .1651 & .2000 & .125 & .0099 \\
\hline & 15 & .0009 & .4000 & 4.716 & .1651 & .2000 & .125 & .0099 \\
\hline \multirow[t]{2}{*}{$F$} & 16 & .0009 & .4000 & 4.795 & .1566 & .2000 & .125 & .0067 \\
\hline & 17 & .0009 & .4000 & 4.795 & .1566 & .2000 & .125 & .0067 \\
\hline \multirow[t]{3}{*}{ G } & 18 & .0009 & .4000 & 5.006 & .3400 & .3000 & .125 & .0149 \\
\hline & 19 & .0009 & .4000 & 5.006 & .3400 & .3000 & .125 & .0149 \\
\hline & 20 & .0009 & .4000 & 5.006 & .3400 & .3000 & .125 & .0149 \\
\hline \multirow[t]{3}{*}{$H$} & 21 & .0009 & .4000 & 4.928 & .2300 & .2000 & .120 & .0300 \\
\hline & 22 & .0009 & .4000 & 4.928 & .2300 & .2000 & .120 & .0300 \\
\hline & 23 & .0009 & .4000 & 4.928 & .2300 & .2000 & .120 & .0300 \\
\hline \multirow[t]{3}{*}{$\mathrm{I} 2$} & 24 & .0009 & .5000 & 3.874 & .4200 & .2000 & .050 & .0020 \\
\hline & 25 & .0009 & .5000 & 3.874 & .4200 & .2000 & .050 & .0020 \\
\hline & 26 & .0009 & .5000 & 3.874 & .4200 & .2000 & .050 & .0020 \\
\hline \multirow[t]{3}{*}{ I } & 27 & .0009 & .4000 & 4.928 & .2300 & .2000 & .120 & .0300 \\
\hline & 28 & .0009 & .4000 & 4. 928 & .2300 & .2000 & .120 & .0300 \\
\hline & 29 & .0009 & .4000 & 4.928 & .2300 & .2000 & .120 & .0300 \\
\hline \multirow[t]{3}{*}{ J } & 30 & .0009 & .4000 & 4.928 & .2300 & .2000 & .120 & .0300 \\
\hline & 31 & .0009 & .4000 & 4.928 & .2300 & .2000 & .120 & .0300 \\
\hline & 32 & .0009 & .4000 & 4.928 & .2300 & .2000 & .120 & .0300 \\
\hline \multirow[t]{3}{*}{ K } & 33 & .0009 & .4000 & 5.006 & .2700 & .2000 & .150 & .0100 \\
\hline & 34 & .0009 & .4000 & 5.006 & .2700 & .2000 & .150 & .0100 \\
\hline & 35 & .0009 & .4000 & 5.006 & .2700 & .2000 & .150 & .0100 \\
\hline \multirow[t]{3}{*}{$L$} & 36 & .0009 & .4000 & 6.884 & .5466 & .2000 & .125 & .0094 \\
\hline & 37 & .0009 & .4000 & 6.884 & .5466 & .2000 & .125 & .0094 \\
\hline & 38 & .0009 & .4000 & 6.884 & .5466 & .2000 & .125 & .0094 \\
\hline \multirow[t]{3}{*}{ M } & 39 & .0009 & .3524 & 5.006 & .3111 & .2000 & .255 & .0200 \\
\hline & 40 & .0009 & .3524 & 5.006 & .3111 & .2000 & .255 & .0200 \\
\hline & 41 & .0009 & .3524 & 5.006 & .3111 & .2000 & .255 & .0200 \\
\hline \multirow[t]{3}{*}{$N$} & 42 & .0009 & .4000 & 5.006 & .3111 & .2000 & .100 & .0065 \\
\hline & 43 & .0009 & .4000 & 5.006 & .3111 & .2000 & .100 & .0065 \\
\hline & 44 & .0009 & .4000 & 5.006 & .3111 & .2000 & .100 & .0065 \\
\hline
\end{tabular}




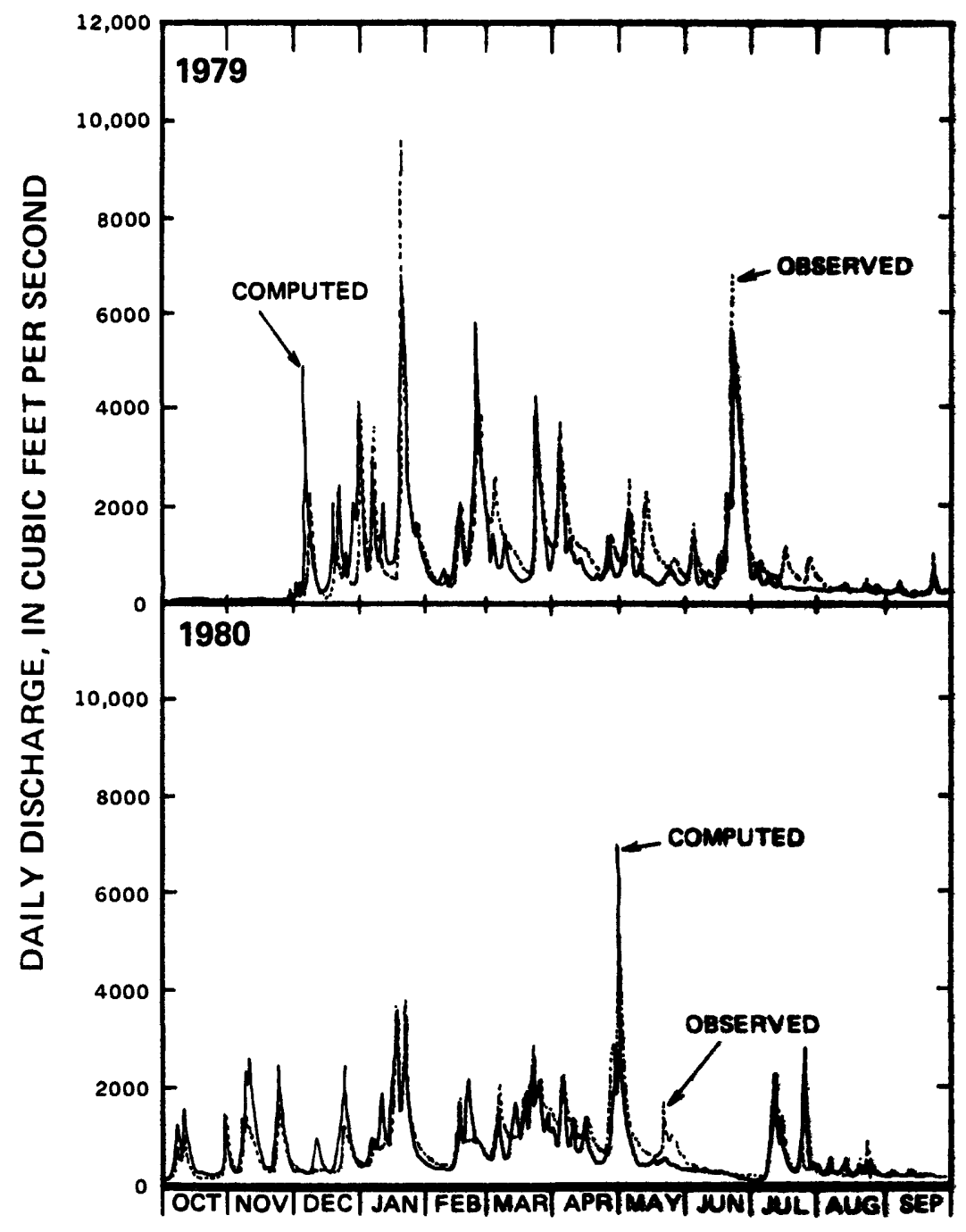

Figure 9.--Observed and computed mean daily discharge hydrographs for Tug Fork at Litwar, W. Va., for water years 1979 and 1980. 
Since there was little change from 1950 to 1960 in the drainage areas that were disturbed by surface mining, the 1950 and 1960 landuse data were averaged to define mined and reclaimed areas in the basin. Each of the 44 HRU's were subsequently redefined with drainage areas corresponding to the earlier period land-use definition. The parameters optimized and adjusted in the 1980 calibration--SCN, SCl, SMAX, SEP, RCF, RCP, and RCB--were again analyzed during the 1950 calibration. Several optimization and calibration runs were made with these parameters being assigned initial values equal to the final 1980 calibration results. The model simulations did not improve significantly when the parameters were changed from the initial values. It must be emphasized that with only three available streamflow gaging stations during the earlier period, the information needed for spatial definition of these parameters is limited. However, it is reasonable to expect that these parameters should not differ appreciably from 1980 values since overall physical characteristics of the basin have changed very little since 1950. Therefore, the only change in the earlier period model was the size of areas defined as mined, reclaimed, and other. Table 9 lists the drainage areas in acres for the 44 HRUs. Other information about each HRU remained the same as presented in table 8. Figure 10 shows observed and computed discharge hydrographs for the Tug Fork at Litwar, W. Va., for water years 1952 and 1953.

\section{SIMULATION AND FREQUENCY ANAL YSIS OF LONG-TERM STREAMFLOW TIME SERIES}

Long-term daily rainfall data (1951-1980) measured at three basin gages (Gary W. Va., Williamson, W. Va., and Louisa, Ky.) were used in the model for both calibrated conditions, and daily-mean streamflow representing 1950 and 1980 land-use conditions were simulated. Model output was generated at the 15 sites shown in table 1. Tables 10, 11, and 12 list both observed and computed highest and second highest annual discharges for selected years at the three long-term gaging stations, Tug Fork at Litwar, W. Va., Panther Creek near Panther, W. Va., and Tug Fork near Kermit, W. $\mathrm{Va}$. The computed errors for the streamflow time series representing 1950 land-use conditions were based on 1952-1960 data at Tug Fork at Litwar, W. Va., and Tug Fork near Kermit, W. Va. Errors for the 1980 streamflow time series were based on 1976-1980 data at these same two stations. Since little mining occurred in the Panther Creek near Panther, W. Va., basin from 1950 to 1980 , errors were computed for the entire period (1952-1980) for only the 1980 discharge time series. Average errors for the highest and second highest annual predicted discharges were: Tug Fork at Litwar, W. $\mathrm{Va} ., 3.5$ and -9.7 percent, respectively, and Tug Fork near Kermit, W. Va., -20.6 and -10.9 percent. The same two average errors for Panther Creek near Panther, W. Va., were -24.7 and -23.7 percent. Since the 1980 calibrated model was used entirely for the Panther Creek analysis, the closeness of the average error indicates the model is consistent for reproducing higher flows at the Panther Creek outlet. In addition, tables 10, 11, and 12 list the number 
Table 9.--Drainage areas corresponding to the early period (1950) land-use conditions for each hydrologic response unit

\begin{tabular}{|c|c|c|c|}
\hline $\begin{array}{l}\text { Reference } \\
\text { point } \\
\text { (see } \\
\text { table } 1 \text { ) }\end{array}$ & $\begin{array}{c}\text { Hydrologic } \\
\text { Response } \\
\text { Unit }\end{array}$ & $\begin{array}{l}\text { Area } \\
\text { (acres) }\end{array}$ & Land use \\
\hline \multirow[t]{3}{*}{ A } & 1 & 387 & Mined \\
\hline & 2 & 0 & Reclaimed \\
\hline & 3 & 47152 & Other \\
\hline \multirow[t]{3}{*}{ B } & 4 & 119 & Mined \\
\hline & 5 & 0 & Reclaimed \\
\hline & 6 & 55732 & Other \\
\hline \multirow[t]{3}{*}{ C } & 7 & 0 & Mined \\
\hline & 8 & 0 & Reclaimed \\
\hline & 9 & 2002 & Other \\
\hline \multirow[t]{3}{*}{ D } & 10 & 143 & Mined \\
\hline & 11 & 0 & Recla imed \\
\hline & 12 & 68597 & Other \\
\hline \multirow[t]{3}{*}{$E$} & 13 & 463 & Mined \\
\hline & 14 & 0 & Reclaimed \\
\hline & 15 & 145606 & Other \\
\hline \multirow[t]{2}{*}{$F$} & 16 & 0 & Mined \\
\hline & 17 & 7663 & Other \\
\hline \multirow[t]{3}{*}{ G } & 18 & 11 & Mined \\
\hline & 19 & 0 & Reclaimed \\
\hline & 20 & 20004 & other \\
\hline \multirow[t]{3}{*}{$H$} & 21 & 6 & Mined \\
\hline & 22 & 0 & Reclaimed \\
\hline & 23 & 16513 & Other \\
\hline \multirow[t]{3}{*}{ I2 } & 24 & 86 & Mined \\
\hline & 25 & 0 & Reclaimed \\
\hline & 26 & 54616 & Other \\
\hline \multirow[t]{3}{*}{ I } & 27 & 1743 & Mined \\
\hline & 28 & 0 & Reclaimed \\
\hline & 29 & 145528 & Other \\
\hline \multirow[t]{3}{*}{$\mathrm{J}$} & 30 & 377 & Mined \\
\hline & 31 & 5 & Recl a imed \\
\hline & 32 & 40132 & Other \\
\hline \multirow[t]{3}{*}{$k$} & 33 & 71 & Mined \\
\hline & 34 & 0 & Reclaimed \\
\hline & 35 & 60863 & Other \\
\hline \multirow[t]{3}{*}{$L$} & 36 & 126 & Mined \\
\hline & 37 & 0 & Recl a imed \\
\hline & 38 & 102765 & Other \\
\hline \multirow[t]{3}{*}{$M$} & 39 & 0 & Mined \\
\hline & 40 & 0 & Reclaimed \\
\hline & 41 & 40778 & other \\
\hline \multirow[t]{3}{*}{$\mathrm{N}$} & 42 & 28 & Mined \\
\hline & 43 & 0 & Reclaimed \\
\hline & 44 & 166051 & Other \\
\hline
\end{tabular}




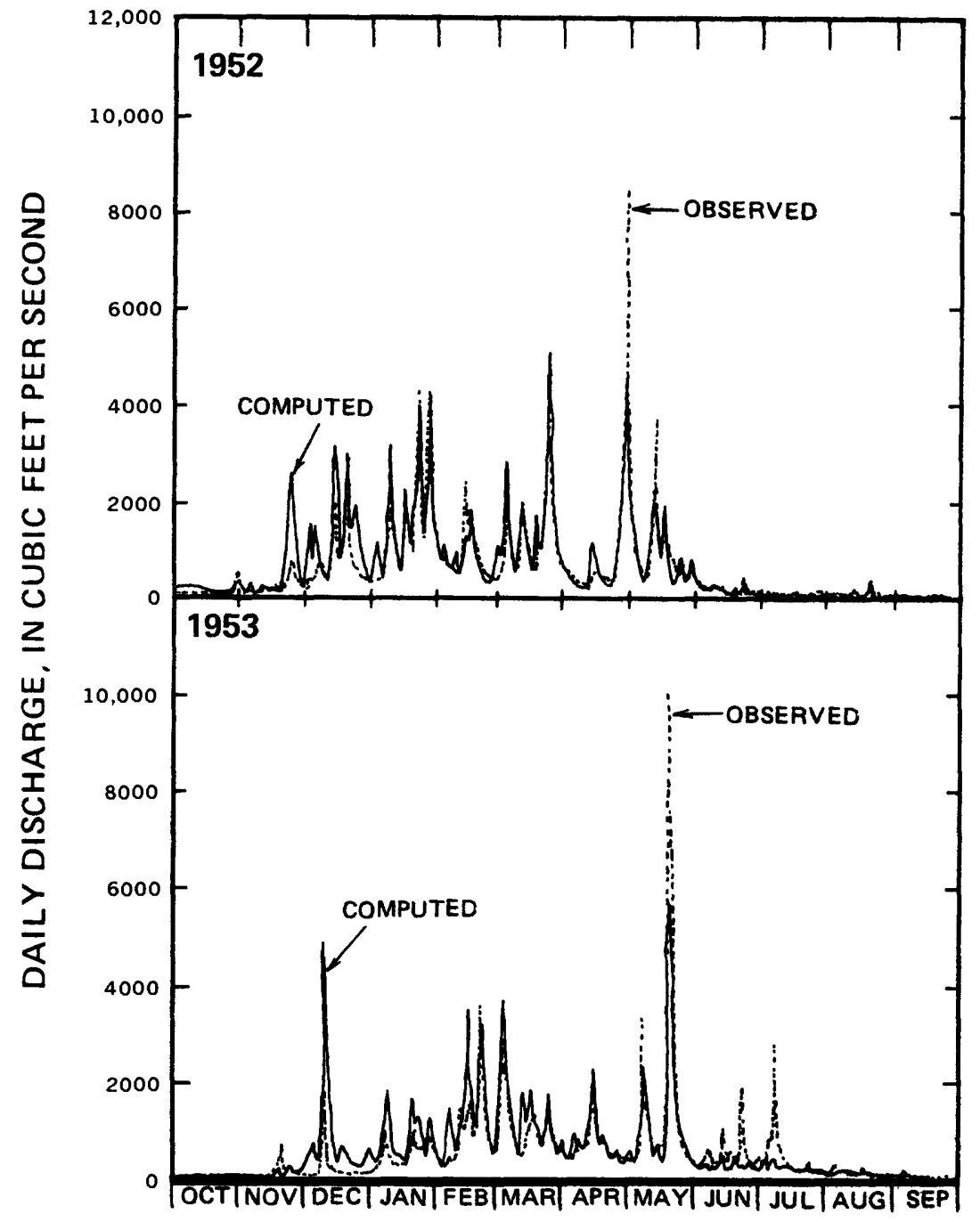

Figure 10.--Observed and computed mean daily discharge hydrographs for Tug Fork at Litwar, W. Va., for water years 1952 and 1953. 
Table 10.--Difference between observed and computed streamflow at

station 03213000, Tug Fork at Litwar, W. Va.

Highest annual discharge*

in cubic feet per second
Second highest annual discharge*

in cubic feet per second

Year Observed Predicted Percentage Observed Predicted Percentage Error*

Error*

Results using 1950 calibrated model

$\begin{array}{rrrrrrr}1952 & 8,440 & 4,522 & -46 & 5,190 & 4,073 & -22 \\ 1953 & 10,100 & 5,486 & -46 . & 3,650 & 3,326 & -9 . \\ 1954 & 7,770 & 25,716 & 231 . & 4,980 & 2,349 & -53 . \\ 1955 & 15,000 & 11,211 & -25 . & 5,400 & 3,681 & -32 . \\ 1956 & 9,700 & 7,694 & -21 . & 4,810 & 4,216 & -12 . \\ 1957 & 19,000 & 12,245 & -36 . & 4,240 & 5,672 & 34 . \\ 1958 & 9,700 & 7,604 & -22 . & 8,760 & 6,314 & -28 . \\ 1959 & 4,810 & 3,997 & -17 . & 3,720 & 2,491 & -33 . \\ 1960 & 3,130 & 5,461 & 74 . & 2,550 & 2,147 & -16 .\end{array}$

Results using 1980 calibrated model

\begin{tabular}{|c|c|c|c|c|c|c|}
\hline $\begin{array}{l}1976 \\
1977 \\
1978 \\
1979 \\
1980\end{array}$ & $\begin{array}{r}3,640 \\
22,000 \\
15,500 \\
9,620 \\
6,311\end{array}$ & $\begin{array}{r}5,084 \\
24,130 \\
3,224 \\
7,162 \\
7,063\end{array}$ & $\begin{array}{c}40 \\
10 \\
-79 \\
-26 \\
12\end{array}$ & $\begin{array}{l}2,650 \\
4,370 \\
6,990 \\
6,920 \\
3,820\end{array}$ & $\begin{array}{l}2,557 \\
7,135 \\
6,471 \\
5,627 \\
3,880\end{array}$ & $\begin{array}{r}-4 . \\
63 \\
-7 \\
-19 . \\
2 .\end{array}$ \\
\hline Average & 10,337 & 9,328 & 3.5 & 4,861 & 4,281 & -9.7 \\
\hline \multicolumn{3}{|c|}{$\begin{array}{l}\text { Number of }+ \text { errors } \\
\text { Number of }- \text { errors } \\
\text { Percent of }+ \text { errors } \\
\text { Percent of - errors }\end{array}$} & $\begin{array}{c}5 \\
9 \\
35.7 \\
64.3\end{array}$ & & & $\begin{array}{l}3 \\
11 \\
21.4 \\
78.6\end{array}$ \\
\hline
\end{tabular}

*Based on observed discharge. 
Table 11.--Difference between observed and computed streamflow at station 03213500, Panther Creek near Panther, W. Va.

Highest annual discharge* in cubic feet per second
Second highest annual discharge* in cubic feet per second

Year Observed Predicted Percentage Observed Predicted Percentage Error*

Error*

Results using 1980 calibrated model

\begin{tabular}{|c|c|c|c|c|c|c|}
\hline $\begin{array}{l}1952 \\
1953 \\
1954 \\
1955 \\
1956 \\
1957 \\
1958 \\
1959 \\
1960 \\
1961 \\
1962 \\
1963 \\
1964 \\
1965 \\
1966 \\
1967 \\
1968 \\
1969 \\
1970 \\
1971 \\
1972 \\
1973 \\
1974 \\
1975 \\
1976 \\
1977 \\
1978 \\
1979 \\
1980\end{array}$ & $\begin{array}{r}804 \\
731 \\
301 \\
1430 \\
825 \\
2250 \\
730 \\
909 \\
439 \\
760 \\
690 \\
2090 \\
389 \\
799 \\
585 \\
1290 \\
492 \\
176 \\
795 \\
671 \\
855 \\
890 \\
1060 \\
910 \\
247 \\
2300 \\
1100 \\
955 \\
332\end{array}$ & $\begin{array}{r}372 \\
444 \\
211 \\
810 \\
600 \\
919 \\
598 \\
201 \\
426 \\
139 \\
425 \\
1059 \\
226 \\
446 \\
664 \\
630 \\
385 \\
236 \\
373 \\
855 \\
703 \\
752 \\
642 \\
904 \\
436 \\
1830 \\
285 \\
577 \\
566\end{array}$ & 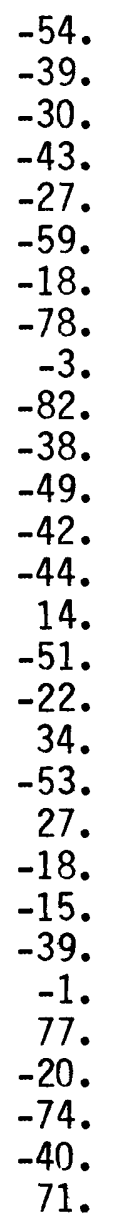 & $\begin{array}{r}764 \\
514 \\
281 \\
1160 \\
618 \\
398 \\
539 \\
493 \\
305 \\
575 \\
401 \\
1020 \\
386 \\
767 \\
522 \\
499 \\
300 \\
139 \\
598 \\
409 \\
847 \\
682 \\
606 \\
706 \\
229 \\
658 \\
488 \\
756 \\
242\end{array}$ & $\begin{array}{r}329 \\
265 \\
305 \\
805 \\
429 \\
467 \\
534 \\
316 \\
187 \\
407 \\
247 \\
676 \\
433 \\
934 \\
519 \\
201 \\
145 \\
33 \\
263 \\
304 \\
346 \\
682 \\
507 \\
467 \\
210 \\
608 \\
530 \\
429 \\
304\end{array}$ & 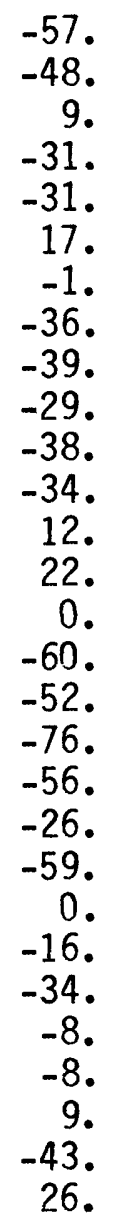 \\
\hline Average & 890 & 576 & -24.7 & 54.8 & 402 & -23.7 \\
\hline \multicolumn{3}{|c|}{$\begin{array}{l}\text { Number of }+ \text { errors } \\
\text { Number of - errors } \\
\text { Percent of + errors } \\
\text { Percent of - errors }\end{array}$} & $\begin{array}{l}5 \\
24 \\
17.2 \\
82.8\end{array}$ & & & $\begin{array}{l}6 \\
22 \\
21.4 \\
78.6\end{array}$ \\
\hline
\end{tabular}

*Based on observed discharge. 
Table 12.--Difference between observed and computed streamflow at station 03214000, Tug Fork near Kermit, W. Va.

Highest annual discharge* in cubic feet per second
Second highest annual discharge* in cubic feet per second

Year Observed Predicted Percentage Observed Predicted Percentage Error*

Error*

Results using 1950 calibrated model

\begin{tabular}{rrrrrrr}
\hline 1952 & 25,200 & 13,826 & -45. & 15,600 & 5,800 & -63. \\
1953 & 16,400 & 6,774 & -59. & 10,300 & 6,349 & -38. \\
1954 & 12,800 & 28,448 & 122. & 5,770 & 13,431 & 133. \\
1955 & 41,300 & 25,777 & -38. & 12,000 & 8,227 & -31. \\
1956 & 28,100 & 16,160 & -42. & 16,900 & 16,637 & -2. \\
1957 & 52,900 & 21,150 & -60. & 17,200 & 12,646 & -26. \\
1958 & 39,200 & 21,755 & -45. & 10,900 & 7,881 & -28. \\
1959 & 12,000 & 7,211 & -40. & 8,740 & 8,125 & -7. \\
1960 & 6,430 & 11,804 & 84. & 6,360 & 6,388 & 0. \\
\hline
\end{tabular}

Results using 1980 calibrated model

\begin{tabular}{|c|c|c|c|c|c|c|}
\hline $\begin{array}{l}1976 \\
1977 \\
1978 \\
1979 \\
1980\end{array}$ & $\begin{array}{r}9,640 \\
78,000 \\
38,080 \\
33,200 \\
8,780\end{array}$ & $\begin{array}{r}10,500 \\
31,764 \\
3,627 \\
27,841 \\
7,935\end{array}$ & $\begin{array}{l}9 . \\
-59 . \\
-90 \\
-16 \\
-10\end{array}$ & $\begin{array}{r}7,570 \\
22,000 \\
21,900 \\
30,300 \\
7,000\end{array}$ & $\begin{array}{r}11,858 \\
11,708 \\
13,523 \\
14,039 \\
6,358\end{array}$ & $\begin{array}{l}57 . \\
-47 \\
-38 . \\
-54 \\
-9 .\end{array}$ \\
\hline Average & 28,716 & 16,755 & -20.6 & 13,752 & 10,212 & -10.9 \\
\hline \multicolumn{3}{|c|}{$\begin{array}{l}\text { Number of }+ \text { errors } \\
\text { Number of - errors } \\
\text { Percent of }+ \text { errors } \\
\text { Percent of - errors }\end{array}$} & $\begin{array}{l}3 \\
11 \\
21.4 \\
78.6\end{array}$ & & & $\begin{array}{l}3 \\
11 \\
21.4 \\
78.6\end{array}$ \\
\hline
\end{tabular}

*Based on observed discharge. 
and percent of positive (+) and negative (-) errors which indicate that the model underestimates peak flows. It is interesting to note that the percent of negative and positive errors for the second highest discharge were, respectively, 78.6 and 21.4 percent at all three locations.

A statistical frequency analysis was performed on each longterm streamflow time series generated by the model for the 1950 and 1980 calibrated conditions. A Geological Survey streamflow statistics computer program A969 (Meeks, 1975) was used to produce flow-duration tables, low-flow and high-flow sequence summaries, and fit the lowflow and high-flow data to a log-Pearson Type III frequency distribution. Annual peak discharges are considered a succession of random events which can be described by the log-Pearson Type III distribution with the parameters mean, standard deviation, and skew coefficient (Water Resources Council, 1981). For this analysis, the skew coefficient was not weighted with an assigned regional value.

Table 13 lists frequency-analysis results for all 15 points of interest for both the 1950 and 1980 model simulations. No trend is evident from these data. The greatest difference is less than 1 percent.

\section{DETECTION OF HYDROLOGIC CHANGE}

Annual 1-day high flows were selected from both long-term streamflow time series. These data were analyzed with several statistical tests to determine if there is a significant difference between them. Two standard nonparametric statistical tests -- (1) the Sign Test (Dixon and Massey, 1957), and (2) the Mann-Whitney Test (Shiau and Condie, 1980) -- were used to test the two time series for homogeneity. In addition, a linear-regression analysis was performed on the data to study the relationships between the two series at each of the 15 locations.

\section{Statistical Tests for Differences}

The following steps were used in performing the two nonparametric statistical tests:

(a) The null hypothesis, $H_{0}$, stated that there was no difference between the two time series.

(b) Significance levels, $\alpha=0.05$ and $\alpha=0.01$ were selected.

(c) The test statistic for each test was computed.

(d) A region of rejection was defined for the chosen significance level.

(e) If the computed test statistic lies in the region of rejection, then the null hypothesis is rejected. 
Table 13.--Frequency analysis results for Tug Fork stations for 1950 and 1980 basin conditions, annual 1-day high streamflow in cubic feet per second

\begin{tabular}{|c|c|c|c|c|c|c|c|c|c|c|}
\hline \multirow{2}{*}{\multicolumn{2}{|c|}{$\begin{array}{l}\text { Reference } \\
\text { point } \\
\text { (See Table } \\
\text { 1) }\end{array}$}} & \multirow[t]{2}{*}{ Name } & \multirow{2}{*}{$\begin{array}{l}\text { Calibra- } \\
\text { tion used }\end{array}$} & \multicolumn{7}{|c|}{ Recurrence interval } \\
\hline & & & & \multirow{2}{*}{$\begin{array}{c}\begin{array}{c}2 \\
\text { year }\end{array} \\
806 \\
806\end{array}$} & \multirow{2}{*}{$\begin{array}{c}5 \\
\text { year } \\
1227 \\
1226\end{array}$} & \multirow{2}{*}{$\begin{array}{c}\begin{array}{c}10 \\
\text { year }\end{array} \\
1581 \\
1580\end{array}$} & \multirow{2}{*}{$\begin{array}{l}25 \\
\text { year } \\
2128 \\
2127\end{array}$} & \multirow{2}{*}{$\begin{array}{l}\begin{array}{l}50 \\
\text { year }\end{array} \\
2618 \\
2618\end{array}$} & \multirow{2}{*}{$\begin{array}{l}\begin{array}{l}100 \\
\text { year }\end{array} \\
3187 \\
3189\end{array}$} & \multirow{2}{*}{$\begin{array}{l}\begin{array}{l}200 \\
\text { year }\end{array} \\
3849 \\
3853\end{array}$} \\
\hline A & $\begin{array}{l}\text { Elkh } \\
\text { Mai }\end{array}$ & $\begin{array}{l}\text { orn Cr. at } \\
\text { tland, W. Va. }\end{array}$ & $\begin{array}{l}1950 \\
1980\end{array}$ & & & & & & & \\
\hline B & $\begin{array}{l}\text { Tug } \\
\text { Wel }\end{array}$ & $\begin{array}{l}\text { Fork at } \\
\text { ch, w. Va. }\end{array}$ & $\begin{array}{l}1950 \\
1980\end{array}$ & $\begin{array}{l}1360 \\
1357\end{array}$ & $\begin{array}{l}2085 \\
2082\end{array}$ & $\begin{array}{l}2713 \\
2711\end{array}$ & $\begin{array}{l}3707 \\
3711\end{array}$ & $\begin{array}{l}4617 \\
4628\end{array}$ & $\begin{array}{l}5694 \\
5715\end{array}$ & $\begin{array}{l}6969 \\
7006\end{array}$ \\
\hline C & $\begin{array}{l}\text { Tug } \\
\text { Wel }\end{array}$ & $\begin{array}{l}\text { Fork below } \\
\text { ch, w. Va. }\end{array}$ & $\begin{array}{l}1950 \\
1980\end{array}$ & $\begin{array}{l}2216 \\
2213\end{array}$ & $\begin{array}{l}3385 \\
3382\end{array}$ & $\begin{array}{l}4387 \\
4385\end{array}$ & $\begin{array}{l}5959 \\
5962\end{array}$ & $\begin{array}{l}7387 \\
7395\end{array}$ & $\begin{array}{l}9066 \\
9083\end{array}$ & $\begin{array}{l}11042 \\
11070\end{array}$ \\
\hline D & $\begin{array}{c}\text { Tug } \\
\text { Iaes }\end{array}$ & $\begin{array}{l}\text { Fork at } \\
\text { ger, W. Va. }\end{array}$ & $\begin{array}{l}1950 \\
1980\end{array}$ & $\begin{array}{l}3837 \\
3832\end{array}$ & $\begin{array}{l}5863 \\
5859\end{array}$ & $\begin{array}{l}7594 \\
7597\end{array}$ & $\begin{array}{l}10306 \\
10325\end{array}$ & $\begin{array}{l}12762 \\
12802\end{array}$ & $\begin{array}{l}15645 \\
15715\end{array}$ & $\begin{array}{l}19030 \\
19143\end{array}$ \\
\hline$E$ & $\begin{array}{l}\text { Dry } \\
\text { Avor }\end{array}$ & $\begin{array}{l}\text { Fork } \mathrm{Cr}_{\text {. }} \text { at } \\
\text { ndale, W. Va. }\end{array}$ & $\begin{array}{l}1950 \\
1980\end{array}$ & $\begin{array}{l}3480 \\
3475\end{array}$ & $\begin{array}{l}5297 \\
5291\end{array}$ & $\begin{array}{l}6847 \\
6840\end{array}$ & $\begin{array}{l}9269 \\
9265\end{array}$ & $\begin{array}{l}11461 \\
11460\end{array}$ & $\begin{array}{l}14028 \\
14033\end{array}$ & $\begin{array}{l}17041 \\
17055\end{array}$ \\
\hline$F$ & $\begin{array}{l}\text { Tug } 1 \\
\text { Liti }\end{array}$ & $\begin{array}{l}\text { Fork at } \\
\text { war, W. Va. }\end{array}$ & $\begin{array}{l}1950 \\
1980\end{array}$ & $\begin{array}{l}7489 \\
7488\end{array}$ & $\begin{array}{l}11421 \\
11423\end{array}$ & $\begin{array}{l}14782 \\
14785\end{array}$ & $\begin{array}{l}20046 \\
20052\end{array}$ & $\begin{array}{l}24816 \\
24825\end{array}$ & $\begin{array}{l}30413 \\
30425\end{array}$ & $\begin{array}{l}36989 \\
37005\end{array}$ \\
\hline G & $\begin{array}{r}\text { Pant } \\
\text { Pant }\end{array}$ & $\begin{array}{l}\text { her } \mathrm{Cr} \text {. near } \\
\text { ther, w. Va. }\end{array}$ & $\begin{array}{l}1950 \\
1980\end{array}$ & $\begin{array}{l}613 \\
613\end{array}$ & $\begin{array}{l}908 \\
908\end{array}$ & $\begin{array}{l}1152 \\
1152\end{array}$ & $\begin{array}{l}1523 \\
1523\end{array}$ & $\begin{array}{l}1849 \\
1849\end{array}$ & $\begin{array}{l}2224 \\
2224\end{array}$ & $\begin{array}{l}2655 \\
2655\end{array}$ \\
\hline$H$ & $\begin{array}{c}\text { Tug } \\
\text { Pant }\end{array}$ & $\begin{array}{l}\text { Fork below } \\
\text { ther, W. Va. }\end{array}$ & $\begin{array}{l}1950 \\
1980\end{array}$ & $\begin{array}{l}8166 \\
8168\end{array}$ & $\begin{array}{l}12359 \\
12362\end{array}$ & $\begin{array}{l}15912 \\
15916\end{array}$ & $\begin{array}{l}21435 \\
21442\end{array}$ & $\begin{array}{l}26406 \\
26415\end{array}$ & $\begin{array}{l}32208 \\
32219\end{array}$ & $\begin{array}{l}38987 \\
39001\end{array}$ \\
\hline I & $\begin{array}{l}\text { Tug } 1 \\
\text { Mate }\end{array}$ & $\begin{array}{l}\text { Fork at } \\
\text { ewan, W. Va. }\end{array}$ & $\begin{array}{l}1950 \\
1980\end{array}$ & $\begin{array}{l}12879 \\
12884\end{array}$ & $\begin{array}{l}18365 \\
18384\end{array}$ & $\begin{array}{l}22033 \\
22071\end{array}$ & $\begin{array}{l}26687 \\
26759\end{array}$ & $\begin{array}{l}30163 \\
30267\end{array}$ & $\begin{array}{l}33644 \\
33784\end{array}$ & $\begin{array}{l}37152 \\
37335\end{array}$ \\
\hline I2 & $\begin{array}{r}\text { Knox } \\
\text { Kel }\end{array}$ & $\begin{array}{l}\text { Cr. near } \\
\text { sa, Va. }\end{array}$ & $\begin{array}{l}1950 \\
1980\end{array}$ & $\begin{array}{l}2075 \\
2077\end{array}$ & $\begin{array}{l}3002 \\
3004\end{array}$ & $\begin{array}{l}3611 \\
3610\end{array}$ & $\begin{array}{l}4370 \\
4363\end{array}$ & $\begin{array}{l}4926 \\
4913\end{array}$ & $\begin{array}{l}5473 \\
5454\end{array}$ & $\begin{array}{l}6017 \\
5989\end{array}$ \\
\hline J & $\begin{array}{l}\text { Tug } \\
\text { Wi1 }\end{array}$ & $\begin{array}{l}\text { Fork at } \\
\text { liamson, W. Va. }\end{array}$ & $\begin{array}{l}1950 \\
1980\end{array}$ & $\begin{array}{l}13914 \\
13920\end{array}$ & $\begin{array}{l}19818 \\
19838\end{array}$ & $\begin{array}{l}23678 \\
23716\end{array}$ & $\begin{array}{l}28481 \\
28547\end{array}$ & $\begin{array}{l}32000 \\
32092\end{array}$ & $\begin{array}{l}35470 \\
35592\end{array}$ & $\begin{array}{l}38915 \\
39071\end{array}$ \\
\hline K & $\begin{array}{l}\text { Pigec } \\
\text { Lenc }\end{array}$ & $\begin{array}{l}\text { on } C_{r} \text { near } \\
\text { ore, w. Va. }\end{array}$ & $\begin{array}{l}1950 \\
1980\end{array}$ & $\begin{array}{l}1985 \\
1985\end{array}$ & $\begin{array}{l}2919 \\
2918\end{array}$ & $\begin{array}{l}3529 \\
3529\end{array}$ & $\begin{array}{l}4286 \\
4285\end{array}$ & $\begin{array}{l}4838 \\
4836\end{array}$ & $\begin{array}{l}5378 \\
5375\end{array}$ & $\begin{array}{l}5910 \\
5907\end{array}$ \\
\hline$L$ & $\begin{array}{c}\text { Tug } F \\
\text { Kern }\end{array}$ & $\begin{array}{l}\text { Fork near } \\
\text { nit, W. Va. }\end{array}$ & $\begin{array}{l}1950 \\
1980\end{array}$ & $\begin{array}{l}16243 \\
16235\end{array}$ & $\begin{array}{l}22824 \\
22811\end{array}$ & $\begin{array}{l}26930 \\
26915\end{array}$ & $\begin{array}{l}31833 \\
31820\end{array}$ & $\begin{array}{l}35292 \\
35282\end{array}$ & $\begin{array}{l}38599 \\
38592\end{array}$ & $\begin{array}{l}41784 \\
41784\end{array}$ \\
\hline M & $\begin{array}{r}\text { Rockc } \\
\text { near }\end{array}$ & $\begin{array}{l}\text { castle } \mathrm{Cr} \\
\text { r Inez, Ky. }\end{array}$ & $\begin{array}{l}1950 \\
1980\end{array}$ & $\begin{array}{l}1055 \\
1055\end{array}$ & $\begin{array}{l}1558 \\
1556\end{array}$ & $\begin{array}{l}1953 \\
1950\end{array}$ & $\begin{array}{l}2529 \\
2525\end{array}$ & $\begin{array}{l}3017 \\
3012\end{array}$ & $\begin{array}{l}3561 \\
3554\end{array}$ & $\begin{array}{l}4167 \\
4158\end{array}$ \\
\hline N & $\begin{array}{l}\text { Tug } F \\
\text { Gler }\end{array}$ & $\begin{array}{l}\text { Fork at } \\
\text { hhayes, W. Va. }\end{array}$ & $\begin{array}{l}1950 \\
1980\end{array}$ & $\begin{array}{l}19843 \\
19823\end{array}$ & $\begin{array}{l}27730 \\
27716\end{array}$ & $\begin{array}{l}32552 \\
32551\end{array}$ & $\begin{array}{l}38209 \\
38233\end{array}$ & $\begin{array}{l}42134 \\
42183\end{array}$ & $\begin{array}{l}45835 \\
45912\end{array}$ & $\begin{array}{l}49355 \\
49464\end{array}$ \\
\hline
\end{tabular}


It was determined that for these two tests, there is no statistically significant difference between the two time series at any of the 15 locations in the basin. Table 14 i ists computed values for the Mann-Whitney test statistic $Z$. As seen, all values are well within the region for accepting the null hypothesis.

In addition, a linear-regression analysis, relating corresponding 1950 and 1980 simulated flood flows, was performed on the data to study the relationships between the two series at each location. At the 98 percent confidence level for a two-tail test, it was determined that the slopes of each relation were not different from unity indicating no difference between the two time series at any of the locations.

\section{Discrepancies in the Modeling Process}

At the outset of the study it was reasoned that a comparison of the long-term streamflow time series generated for 1950 and 1980 land-use conditions may or may not show statistical differences depending on the degree of impact and the model capability to detect impact. Thus, it is important to identify possible discrepancies in the modeling process or "model noise" that may be responsible for overshadowing the difference, if any.

Panther Creek near Panther, W. Va., the smallest $\left(31.0 \mathrm{mi}^{2}\right)$ and least-disturbed (less than 1 percent) subwatershed in the basin was selected for an analysis to determine "model noise." Discharge data are available from 1946 to present and were used to compute an observed frequency distribution of annual one-day high streamflows. Model calibrations were performed with data for the entire 19501980 period and for three separate shorter 1-year periods representing 1 and-use conditions in 1950, 1960, and 1980. The four calibrated models were used to simulate separate long-term streamflow time series using long-term rainfall. Frequency distributions for simulated annual 1-day high streamflows were then computed for each time series. These results are presented in table 15 and it can be seen that all computed annual 1-day high streamflows, except the 2-year 1960 computed value, are less than the corresponding observed streamflow for the same recurrence interval with errors ranging from +1.0 to -24.7 percent. Thus, errors can occur from the years selected for calibration, in this case by as much as 20 percent. Also presented in the table are computed errors for the shorter calibration periods based on the long-term 1950-1980 calibration results. These results show how different time periods can influence model calibration. It can be seen that the 1950 calibration represented the long-term average better than the 1960 and 1980 calibrations. However, the fluctuations for the 1960 and 1980 calibrations were within \pm 10 percent.

There are many sources of error that can contribute to modeling error. Data measurement errors, model parameter errors, and errors in the model's representation of the real world are the most important. For example, Dawdy and Bergmann (1969) stated that with a single rain gage in the basin, peak discharges can at best be 
Table 14.--Results of Mann-Whitney nonparametric statistical test for homogeneity between the 1950 and 1980 streamflow time series

\begin{tabular}{clc}
\hline $\begin{array}{c}\text { Reference } \\
\text { point }\end{array}$ & \multicolumn{1}{c}{ Name } & $\begin{array}{c}\text { Computed } \\
\text { Z statistic* }\end{array}$ \\
\hline A & Elkhorn Cr. at Maitland, W. Va. & -0.086 \\
B & Tug Fork at Welch, W. Va. & -.148 \\
C & Tug Fork bel ow Welch, W. Va. & -.117 \\
D & Tug Fork at Iaeger, W. Va. & -.132 \\
E & Dry Fork Cr. at Avondale, W. Va. & -.132 \\
F & Tug Fork at Litwar, W. Va. & -.117 \\
G & Panther Cr. near Panther, W. Va. & -.078 \\
H & Tug Fork below Panther, W. Va. & -.117 \\
I & Tug Fork at Matewan, W. Va. & -.117 \\
I2 & Knox Cr. near Kelsa, Va. & -.109 \\
J & Tug Fork at Williamson, W. Va. & -.101 \\
K & Pigeon Cr. near Lenore, W. Va. & -.0140 \\
L & Tug Fork near Kermit, W. Va. & -.132 \\
M & Rockcastle Cr. near Inez, Ky & -.101 \\
N & Tug Fork at Glenhayes, W. Va. & -.148 \\
\hline
\end{tabular}

*Region of rejection of null $H_{0}$, that there was no difference between the two time series, for significance level $=0.05, Z<-1.645$; and for significance level $=0.01, Z<-2.326$. 
Table 15.--Frequency analyses for observed, 1950-1980 calibration, 1950-calibration, 1960-calibration, and 1980-calibration streamflow data for Panther Creek near Panther, W. Va.

\begin{tabular}{rccccc}
\hline $\begin{array}{c}\text { Recurrence } \\
\text { interval } \\
\text { (years) }\end{array}$ & Observed & $1950-1980$ & 1950 & 1960 & 1980 \\
\cline { 2 - 6 } & 768 & 701 & 701 & 776 & 631 \\
\hline 2 & 1241 & 1028 & 1028 & 1109 & 935 \\
5 & 1570 & 1294 & 1293 & 1362 & 1182 \\
10 & 1993 & 1693 & 1692 & 1720 & 1551 \\
25 & 2311 & 2040 & 2039 & 2016 & 1871 \\
50 & 2629 & 2434 & 2433 & 2338 & 2235 \\
100 & 2948 & 2883 & 2881 & 2691 & 2648 \\
200 & & & & & \\
\hline
\end{tabular}

Differences, in percent, based on observed streamflow frequencies

\begin{tabular}{rrrrr}
\hline 2 & -8.7 & -8.7 & +1.0 & -17.8 \\
5 & -17.2 & -17.2 & -10.6 & -24.7 \\
10 & -17.6 & -17.6 & -13.2 & -24.7 \\
25 & -15.1 & -15.1 & -13.7 & -22.2 \\
50 & -11.7 & -11.8 & -12.8 & -19.0 \\
100 & -7.4 & -7.5 & -11.1 & -15.0 \\
200 & -2.2 & -2.3 & -8.7 & -10.2 \\
\hline
\end{tabular}

Differences, in percent, based on 1950-1980 calibration

\begin{tabular}{rcrc}
\hline 2 & 0 & +10.7 & -10.0 \\
5 & 0 & +7.9 & -9.0 \\
10 & -0.1 & +5.3 & -8.7 \\
25 & -.1 & +1.6 & -8.4 \\
50 & -.05 & -1.2 & -8.3 \\
100 & -.04 & -3.9 & -8.2 \\
200 & -.07 & -6.7 & -8.2 \\
\hline
\end{tabular}


predicted with a standard error of estimate on the order of 20 percent. Their analysis involved studying the effect of rainfall variability with 3 recording rain gages in a 9.7-square-mile basin in southern California. By far, the most important error in these tests was inadequate representation of actual Panther Creek basin rainfall. Input to the model was rainfall measured at Gary, W. Va., located about 20 miles outside the Panther Creek basin. At times, rainfall was measured at Gary with no corresponding rise in flow on Panther Creek, and vice versa. Thus the significant error and bias in computed flood discharges for Panther Creek may largely be attributed to inadequate rainfall representation.

\section{PRMS APPLICATION TO HYPOTHETICAL MINING LAND-USE SCENARIOS}

An analysis was made with the 1980 calibrated model for several hypothetical future land-use scenarios reflecting various increases in surface-mining activity in a particular part of the basin. Environmental regulations such as Public Law 95-87, the Surface Mining Control and Reclamation Act of 1977, require that the probable hydrologic consequences of mining and the cumulative impacts on the environment be determined as part of the application process for a mining permit.

The 85.8-square-mile subwatershed, Tug Fork at Welch, W. Va., was selected as the area to be hypothetically disturbed and the effect of the disturbance was analyzed at its outlet and at downstream points along the Tug Fork at Litwar, Williamson, Kermit, and GTenhayes. Since 1950 , mining has increased from 0.13 to 10.77 percent in this subwatershed. Hypothetical increases in mining of 50,100 , and 200 percent were simulated by increasing the present mined area to $9.24 \mathrm{mi}^{2}, 13.87 \mathrm{mi}^{2}, 18.48 \mathrm{mi}^{2}$, and $27.72 \mathrm{mi}^{2}$, respectively. Other model parameters remained the same for these analyses. Long-term rainfall data (1951-1980) were input to the model for present land-use conditions and land-use conditions representing the hypothetical mining increases.

Table 16 lists results of frequency analyses performed on each generated discharge time series for annual 1-day high streamflows. The effect at the subwatershed outlet (Tug fork at Welch, W. Va.) even for the greatest increase in mining activities, is only 1.5 percent for the 200-year recurrence interval flow. Downstream at the other stations there is essentially no effect from the increased mining occurring upstream.

As a further check on the potential impact, an additional scenario was simulated. This scenario assumes all precipitation falling on existing surface-mined and reclaimed areas in the Tug Fork basin directly drains to the streams and that none of the precipitation is stored on the surface or infiltrates the soil. This scenario then defines the possible range of impact from surface mining on flooding. Table 17 shows the increases and percent change for five of the points on the main stem of the Tug Fork. The true answer lies somewhere between zero and the increase illustrated for the worst condition in table 17. As the table shows, the percent 
Table 16.--Hypothetical increases in surface mining applied to

85.8-square-mile basin, Tug Fork at Welch, w. Va.,

annual 1-day high streamflow in cubic feet per second

\begin{tabular}{lccccccccccc}
\hline $\begin{array}{l}\text { Station } \\
\text { number }\end{array}$ & $\begin{array}{c}\text { Station } \\
\text { name }\end{array}$ & $\begin{array}{c}\text { Location } \\
\text { river } \\
\text { mile }\end{array}$ & $\begin{array}{c}\text { Percent } \\
\text { increase } \\
\text { in } \\
\text { mining }\end{array}$ & 2 & 5 & 10 & 25 & 50 & 100 & 200 \\
\hline 03212600 & Tug Fork & 135.80 & present & 1357 & 2082 & 2711 & 3711 & 4628 & 5715 & 7006 \\
& at & & 50 & 1358 & 2083 & 2714 & 3716 & 4636 & 5728 & 7025 \\
& Welch, & & 100 & 1358 & 2084 & 2717 & 3723 & 4649 & 5750 & 7058 \\
& W. Va. & & 200 & 1360 & 2088 & 2723 & 3737 & 4672 & 5784 & 7108
\end{tabular}

$\begin{array}{ccccccccccc}03213000 & \text { Tug Fork } & 107.00 & \text { present } & 7488 & 11423 & 14785 & 20052 & 24825 & 30425 & 37005 \\ \text { at } & & 50 & 7486 & 11415 & 14774 & 20037 & 24806 & 30403 & 36980 \\ & \text { Litwar, } & & 100 & 7485 & 11418 & 14783 & 20060 & 24846 & 30468 & 37078 \\ & \text { W. Va. } & & 200 & 7486 & 11417 & 14782 & 20059 & 24846 & 30469 & 37082\end{array}$

$\begin{array}{ccccccccccc}03213700 & \text { Tug Fork } & 57.40 & \text { present } & 13920 & 19838 & 23716 & 28547 & 32092 & 35592 & 39071 \\ \text { at } & & 50 & 13919 & 19838 & 23716 & 28548 & 32095 & 35596 & 39076 \\ \text { Wi1liamson, } & & 100 & 13914 & 19826 & 23699 & 28526 & 32068 & 35566 & 39043 \\ \text { W. Va. } & & 200 & 13915 & 19831 & 23710 & 28547 & 32099 & 35608 & 39098\end{array}$

$03214000 \quad$ Tug Fork $\quad 38.40 \quad$ present $16235 \quad 22811 \quad 26915 \quad 31820 \quad 35282 \quad 38592 \quad 41784$ $\begin{array}{lllllllll}\text { near } & 50 & 16236 & 22810 & 26915 & 31819 & 35282 & 38593 & 41786\end{array}$

$\begin{array}{lllllllll}\text { Kermit, } & 100 & 16236 & 22816 & 26926 & 31839 & 35309 & 38628 & 41829\end{array}$

W. Va. $\quad 200 \quad 16240 \quad 22828 \quad 26944 \quad 31868 \quad 35346 \quad 38674 \quad 41885$

$\begin{array}{clccccccccc}03214900 & \text { Tug Fork } & 9.50 & \text { present } & 19823 & 27716 & 32551 & 38233 & 42183 & 45912 & 49464 \\ & \text { at } & & 50 & 19823 & 27716 & 32551 & 38233 & 42183 & 45912 & 49464 \\ & \text { Glenhayes } & & 100 & 19829 & 27721 & 32552 & 38228 & 42172 & 45894 & 49437 \\ & \text { W. Va. } & & 200 & 19831 & 27725 & 32561 & 38243 & 42192 & 45921 & 49471\end{array}$ 
Table 17.--Comparison of present and worst case mining scenario for entire Tug Fork basin, annual 1-day high streamflow in cubic feet per second

\begin{tabular}{|c|c|c|c|c|c|c|c|c|c|c|}
\hline \multirow{2}{*}{$\begin{array}{l}\text { Station } \\
\text { number }\end{array}$} & \multirow{2}{*}{$\begin{array}{l}\text { Station } \\
\text { name }\end{array}$} & \multirow{2}{*}{$\begin{array}{l}\text { Location } \\
\text { river } \\
\text { mile }\end{array}$} & \multirow{2}{*}{$\begin{array}{c}\text { Mining } \\
\text { condition }\end{array}$} & \multicolumn{7}{|c|}{ Recurrence interval } \\
\hline & & & & 2 & 5 & 10 & 25 & 50 & 100 & 200 \\
\hline 03212 & $\begin{array}{c}\text { Tug Fork } \\
\text { at } \\
\text { Welch, }\end{array}$ & $\begin{array}{r}135.80 \\
\text { Inc }\end{array}$ & $\begin{array}{l}\text { Present } \\
\text { orst case } \\
\text { rease }(\%)\end{array}$ & $\begin{array}{l}1357 \\
1556 \\
14.6\end{array}$ & $\begin{array}{l}2082 \\
2308 \\
10.9\end{array}$ & $\begin{array}{r}2711 \\
2960 \\
9.2\end{array}$ & $\begin{array}{r}3711 \\
3997 \\
7.7\end{array}$ & $\begin{array}{r}4628 \\
4948 \\
6.9\end{array}$ & $\begin{array}{r}5715 \\
6075 \\
6.3\end{array}$ & $\begin{array}{r}7006 \\
7414 \\
5.8\end{array}$ \\
\hline
\end{tabular}

W. Va.

\begin{tabular}{|c|c|c|c|c|c|c|c|c|c|}
\hline 03213000 & $\begin{array}{l}\text { Tug Fork } \\
\text { at } \\
\text { Litwar, }\end{array}$ & 107.00 & $\begin{array}{l}\text { Present } \\
\text { rst case } \\
\text { ease }(\%)\end{array}$ & $\begin{array}{r}7488 \\
8147 \\
8.8\end{array}$ & $\begin{array}{r}11423 \\
12182 \\
6.6\end{array}$ & $\begin{array}{r}14785 \\
15651 \\
5.9\end{array}$ & $\begin{array}{r}20052 \\
21111 \\
5.3\end{array}$ & $\begin{array}{r}24825 \\
26080 \\
5.1\end{array}$ & $\begin{array}{r}30425 \\
31937 \\
5.0\end{array}$ \\
\hline
\end{tabular}
W. Va.

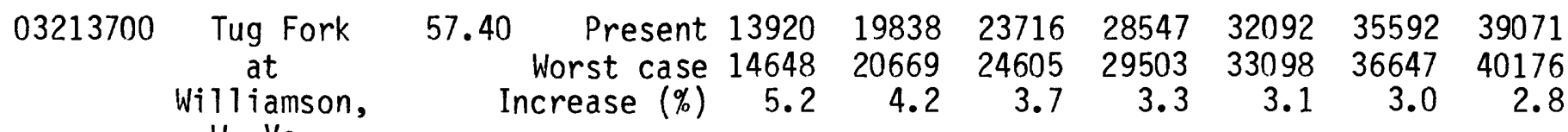
W. Va.

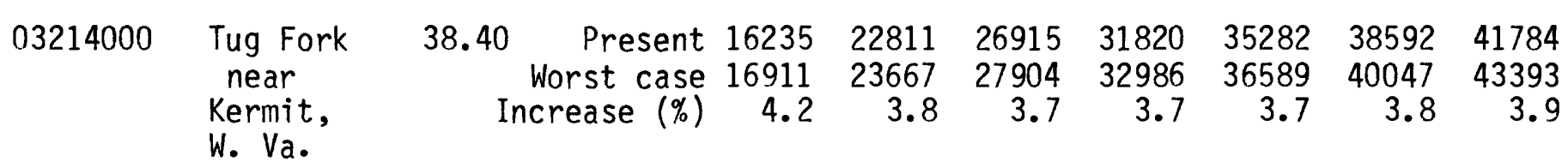

$\begin{array}{rlrrrrrrrr}03214900 & \text { Tug Fork } & 9.50 & \text { Present } 19823 & 27716 & 32551 & 38233 & 42183 & 45912 & 49464 \\ \text { at } & \text { Worst case } & 20508 & 28527 & 33460 & 39285 & 43354 & 47214 & 50906 \\ & \text { Glenhayes } & \text { Increase (\%) } & 3.5 & 2.9 & 2.8 & 2.8 & 2.8 & 2.8 & 2.9 \\ & \text { W. Va. } & & & & & & & & \end{array}$


change is less than 4 percent for all recurrence intervals at the Tug Fork at Glenhayes, W. Va.

The analysis in which hypothetical increases in mining were simulated and the scenario where all areas disturbed by mining were assumed totally impervious allow these conclusions to be made:

1. That the model output is not very sensitive to the parameters that were changed to reflect mining; and

2. The effects of surface mining cause the greatest change near the disturbed area.

\section{SUMMARY}

The Geological Survey PRMS rainfall-runoff model was calibrated and verified for the 1,560-square-mile Tug Fork basin located in Kentucky, Virginia, and West Virginia. Land-use changes have occurred in the basin during the last 30 years and the calibrated model was used to simulate long-term daily streamflow time series corresponding to 1950 and 1980 land-use conditions. The two time series were analyzed at 15 points in the basin to determine if a change in flood characteristics had occurred that could be attributed to surface-mining activities.

Non-parametric statistical tests were used to analyze the series of annual 1-day high flows abstracted from the long-term daily streamflow time series. Results from these statistical analyses indicate that there is no statistical difference between model-generated flood flows with the 1950 and 1980 conditions at any of 15 basin locations. An analysis to determine discrepancies in the modeling process or "model noise" was performed on the leastdisturbed subwatershed in the basin, Panther Creek near Panther, $W$. Va. The results showed that "model noise" can produce bias in the computed frequencies for simulated discharges by as much as 20 percent. Because of data errors, due principally to nonrepresentation of rainfall characteristics, the failure of statistical tests to indicate significant differences between the modeled streamflow time series cannot be stated as conclusive evidence that flood flows have not increased as a result of mining activities.

An analysis was made of the 85.8-square-mile watershed, Tug Fork at Welch, W. Va., in the headwaters of the basin. Hypothetical land-use scenarios were simulated with the model to determine the hydrologic impacts and consequences of increasing mining within the small subwatershed by 50, 100, and 200 percent above present levels. This analysis showed that the increases in surface mining, even for the 200 percent increase, had little effect on streamflow in the immediate area and no effect on streamflow at downstream locations along the Tug Fork. Additional hypothetical conditions were tested with the model by assuming that all precipitation falling on surfacemined and reclaimed areas in the Tug Fork basin drained directly to the stream. These results showed that even if all the areas 
disturbed by mining were made impervious that flows at the basin outlet (Tug Fork at Glenhayes, W. Va.) would only increase by less than 4 percent. However, changes in upstream flows could be more significant. These hypothetical analyses allow these conclusions to be made:

1. That the model output is not very sensitive to the parameters that were changed to reflect mining; and

2. The effects of surface mining cause the greatest change near the disturbed area.

This study has attempted to determine if land-use changes associated with surface mining in the Tug Fork basin have significantly affected the characteristics and patterns of storm runoff in the basin since 1950. The tools and techniques that were used did not prove that there has been a statistically significant change, because modeling discrepancies resulting from limited data were probably larger than possible changes due to surface mining, or the model did not adequately reflect the real changes that were taking place. Until the additional streamflow data from surface mining sites are incorporated, the modeling results obtained in this study must be accepted with reservations.

Hydrologic impacts from surface mining result largely from changes in (1) vegetation, (2) soils, (3) land configuration, and (4) removal of coal aquifers. This study focused primarily on the effects from changes in vegetation because of 1 imited information on basin characteristics and streamflow data from surface mining sites that were not available to calibrate, in detail, the effects of soils, land configuration, and removal of coal aquifers. In order to evaluate the full impact of surface mining, all the changes must be considered. 
Changnon, S. A., Jr., and Vogel, J. L., 1981, Hydrocl imatological characteristics of isolated severe rainstorms: Water Resources Research, v. 17, no. 6, p. 1694-1700.

Chow, V. T., 1964, Handbook of applied hydrology: New York, McGraw-Hi11, 1418 p.

Crowe-Carraco, Carol, 1979, The Big Sandy: The University Press of Kentucky, $136 \mathrm{p}$.

Dawdy, D. R., and Bergmann, J. M., 1969, Effect of rainfall variability on streamflow simulation: Water Resources Research, v. 5, no. 5, October 1969, p. 958-966.

Dixon, W. J., and Massey, F. J, Jr., 1957, Introduction to statistical analysis: New York, McGraw-Hill, 488 p.

Frank, E. C., and Lee, R., 1966, Potential solar beam radiation on slopes: tables for $30^{\circ}$ to $50^{\circ}$ latitude: U.S. Forest Service Research Paper RM-18, $116 \mathrm{p}$.

Green, W. H., and Ampt, C. A., 1911, Studies on soil physics, 1, flow of air and water through soils: Journal of Agricultural Science, v. 4, p. 1-24.

Hewlett, J. D., and Hibbert, A. R., 1967, Factors affecting the response of small watersheds to precipitation in humid areas: in Sopper, W. E., and Lull, H. W., eds., International Symposium of Forest Hydrology: New York, Pergamon Press, p. 275-290.

Hewlett, J. D., and Nutter, W. L., 1970, The varying source area of streamflow from upland basins: Symposium on Interdisciplinary Aspects of Watershed Management, Montana State University, Bozeman, Montana, 1970.

Hirsch, R. M., Scott, A. G., and Wyant, Timothy, 1982, Investigation of trends in flooding in the Tug Fork basin of Kentucky, Virginia, and West Virginia: U.S. Geological Survey Open-File Report 82-263, $83 \mathrm{p}$.

Johanson, R. C., 1971, Precipitation network requirements for streamflow estimation: Technical Report 147, Stanford, Calif., Dept. of Civil Engineering, Stanford University, $199 \mathrm{p}$.

Leclerc, Guy, and Schaake, J. C., Jr., 1973, Methodol ogy for assessing the potential impact of urban development on urban runoff and the relative efficiency of runoff control alternatives: Ralph M. Parsons Laboratory Rept., No. 167, Massachusetts Institute of Technology, 257 p. 
Lumb, A. M., 1982, Procedures for assessment of cumulative impacts of coal mining on the hydrologic balance: U.S. Geological Survey Open-File Report 82-334, 66 p.

McCuen, R. H., Rawls, W. J., and Brakensiek, D. L., 1981, Statistical analysis of the Brooks-Corey and the Green-Ampt parameters across soil textures: Water Resources Research, v. 17, no. 4, p. 1005-1013.

Meeks, W. C., 1975, WATSTORE User's Guide, U.S. Geological Survey Open-File Report 75-426, v. I, chap. IV, sect. G, 37 p.

Mein, R. G., and Larson, C. L., 1973, Modeling infiltration during a steady rain: Water Resources Research, v. 9, no. 2, p. 384-394.

Runner, G. S., 1979, Flood of April 1977 on the Tug Fork, Matewan to Williamson, West Virginia and Kentucky: U.S. Geological Survey Hydrologic Investigations Atlas 588.

Runner, G. S., and Chin, E. H., 1980, Flood of April 1977 in the Appalachian Region of Kentucky, Tennessee, Virginia, and West Virginia: U.S. Geological Survey Professional Paper 1098, 43 p.

Scott, A. G., 1980, An interim report on the investigation of flooding in the Tug Fork Basin of Kentucky, Virginia, and West Virginia: U.S. Geological Survey WRI Open-File Report 80-1188, $116 \mathrm{p}$.

Scott, A. G., and Hirsch, R. M., 1982, Trends in flooding in the Tug Fork basin: Handout for ASCE Hydraulics Division Specialty Conference, Water and Energy, Technical and Policy Issues, Pittsburgh, Pa., 1982, 25 p.

Shiau, Shin-Young, and Condie, R., 1980, Statistical tests for independence, trend, homogeneity and randomness:

Hydrologic Applications Division, Water Resources Branch, Inland Water Directorate, Environment Canada, Ottawa, Ontario KIA 0E7, 44 p.

Showen, C. R., 1978, Storage and retrieval of water-resources data in collection, storage, retrieval, and publication of waterresources data: U.S. Geological Survey Circular 756, p. 20-25.

Troutman, B. M., 1981, The effect of input errors in using precipitation-runoff models for runoff prediction: International Symposium on Rainfall-Runoff Modeling, Mississippi State University, Mississippi State, Miss., 1981, Proceedings, 11 p.

U.S. Department of Agriculture, Soil Conservation Service, 1975, General soil map - Kentucky: 4-R-34874, April, scale 1:750,000. 1979a, General soil map - Virginia: 1-13480, JuTy, scale 1:750,000. 
1979b, General soil map - West Virginia: 15334, December, scale $1: 750,000$.

Water Resources Council, 1981, Guidelines for determining flood flow frequency: Hydrology Committee, Bullet in 17B, Washington, D.C., $28 \mathrm{p}$. 
APPENDIX A

Model Input Data

Model input data values for selected parameters are presented in Appendix A. The variable used to represent the parameter in the model is defined as well as a brief definition of the parameter. 
Cl imate Data

Values for potential shortwave radiation (in Langleys per day) for 24 specific dates from December 22 to June 22 were defined for 6 solar radiation planes.

\begin{tabular}{|c|c|c|c|c|c|c|}
\hline \multirow[t]{3}{*}{$\operatorname{Date}(\mathrm{s})$} & \multicolumn{6}{|c|}{ Shortwave radiation, in Langleys per day } \\
\hline & \multicolumn{6}{|c|}{ Solar radiation plane } \\
\hline & $H O R *$ & $\mathrm{~N} 20$ & NE 10* & NE20 & ENE1 & $\mathrm{E20}$ \\
\hline Dec. 22 & 359.2 & 190.5 & 299.7 & 245.6 & 327.8 & 361.7 \\
\hline Jan. 10, Dec. 3 & 383.6 & 214.5 & 324.3 & 269.9 & 352.3 & 385.8 \\
\hline Jan. 23, Nov. 19 & 425.5 & 257.0 & 366.9 & 312.3 & 394.5 & 427.2 \\
\hline Feb. 7 , Nov. 5 & 485.0 & 319.9 & 428.2 & 374.1 & 454.8 & 486.0 \\
\hline Feb. 20, Oct 22 & 558.4 & 401.2 & 504.8 & 452.5 & 529.9 & 558.4 \\
\hline Mar. 7, Oct. 8 & 639.4 & 495.6 & 590.9 & 541.8 & 613.4 & 638.1 \\
\hline Mar. 21, Sep. 23 & 722.7 & 597.8 & 680.9 & 636.6 & 700.1 & 719.9 \\
\hline Apr. 4, Sep. 9 & 802.1 & 700.2 & 768.3 & 730.4 & 783.6 & 797.8 \\
\hline Apr. 19, Aug. 25 & 872.0 & 794.7 & 846.8 & 815.9 & 857.9 & 866.0 \\
\hline May 3, Aug. 10 & 930.2 & 877.0 & 913.5 & 889.7 & 920.5 & 922.9 \\
\hline May 18, July 27 & 974.3 & 942.0 & 965.1 & 947.6 & 968.4 & 965.8 \\
\hline June 1, July 12 & 1004.0 & 987.3 & 1000.4 & 987.7 & 1001.0 & 994.7 \\
\hline June 22 & 1020.9 & 1013.5 & 1020.6 & 1010.9 & 1019.5 & 1011.1 \\
\hline
\end{tabular}

*For example, HOR is for a horizontal plane and NE10 is for a plane with a northeast aspect and 10 percent slope. 
The monthly values listed below were used to describe the following variables:

PAT, the maximum air temperature (in degrees Fahrenheit) which when exceeded forces precipitation to be rain regardless of minimum temperature.

AJMX, adjustment factor for proportion of rain in a rain-snow mix event.

TLX, lapse rate for maximum daily air temperature.

TLN, lapse rate for minimum daily air temperature.

\begin{tabular}{|c|c|c|c|c|}
\hline Month & PAT & AuMX & $\underline{T L X}$ & $\underline{\mathrm{TLN}}$ \\
\hline January & 50. & 1.0 & 1.5 & 1.5 \\
\hline February & 50. & 1.0 & 1.5 & 1.5 \\
\hline March & 45. & 1.1 & 1.5 & 1.5 \\
\hline April & 40. & 1.2 & 1.5 & .5 \\
\hline May & 40 & 1.1 & 1.5 & 1.5 \\
\hline June & 40. & 1.0 & 1.5 & 1.5 \\
\hline July & 40. & 1.0 & 1.5 & 1.5 \\
\hline August & 40. & 1.0 & 1.5 & 1.5 \\
\hline September & 40. & 1.0 & 1.5 & 1.5 \\
\hline October & 40. & 1.0 & 1.5 & 1.5 \\
\hline November & 50. & 1.0 & 1.5 & 1.5 \\
\hline December & 50. & 1.0 & 1.5 & 1.5 \\
\hline
\end{tabular}


The following variables and associated values were also used in defining Climate Data.

$\underline{\text { Variable }}$ Description

$\underline{\text { Value }}$

PARS Predicted solar radiation correction factor for summer day with precipitation.

PARW Predicted solar radiation correction factor for .50 winter day with precipitation.

RDMX Maximum percent of potential solar radiation.

CSEL Climate station elevation, in feet. 1500.

RMXA

Proportion of rain in a rain-snow precipitation event above which snow albedo is not reset (snowpack accumulation stage).

RMSM

Same as RMXA but for snowpack stage.

CTS

Air temperature ET coefficient.

TST

Temperature index to determine specific date of 1000. start of transpiration.

CTW Proportion of potential evapotranspiration that is sublimated from a snow surface (decimal form).

ISP1 Julian date to start looking for spring snowmelt 60. stage.

ISP2 Julian date to force snowpack to spring snowmelt stage.

$\begin{array}{lll}\text { EAIR Emissivity of dry air. } & .85\end{array}$

FWCAP Free water holding capacity of snowpack expressed $\quad .04$ as a decimal fraction of total snowpack water equivalent.

DENI Initial density of new-fallen snow.

DENMX Average maximum snowpack density.

SETCON Snowpack settlement time constant. 
Subwatershed Reservoir Information

The Tug Fork basin was divided into 15 subwatersheds as identified by outlet in table 1. Each subwatershed had one corresponding subsurface and ground-water reservoir. Some of the coefficients used in relationships to define flow into and out of these reservoirs have already been listed in table 8 (by individual HRU). The remaining coefficients are listed in the table below and their definitions are as follows:

KRSP(I), the index of the ground-water reservoir receiving seepage from subsurface reservoir I; I=1, NRES where NRES equals the number of subsurface flow routing reservoirs (15 in this study).

RES, the initial storage in each subsurface flow routing reservoir, in inches.

GW, the initial storage in each ground-water flow routing reservoir, in inches.

RESMX, coefficient for computing seepage from subsurface reservoir I to its designated ground-water reservoir. REXP, exponent coefficient for computing seepage from subsurface reservoir I to its designated ground-water reservoir. GSNK, coefficient used in computing the seepage rate from ground-water reservoir I to a ground-water sink. 


\begin{tabular}{ccccccc}
\hline $\begin{array}{c}\text { Subwatershed } \\
\text { Out let, } \\
\text { (see reference } \\
\text { point, table 1) }\end{array}$ & $\begin{array}{c}\text { KRSP(I) } \\
\text { I=1,15 }\end{array}$ & $\begin{array}{c}\text { RES } \\
\text { (in } \\
\text { inches) }\end{array}$ & $\begin{array}{c}\text { GW } \\
\text { in } \\
\text { inches) }\end{array}$ & $\begin{array}{c}\text { RESMX } \\
\text { Subsurface } \\
\text { Coefficient }\end{array}$ & $\begin{array}{c}\text { REXP } \\
\text { Subsurface } \\
\text { Exponent } \\
\text { Coefficient }\end{array}$ & $\begin{array}{c}\text { GSNK } \\
\text { Ground- } \\
\text { Water } \\
\text { Coefficient }\end{array}$ \\
\hline A & 1 & 0.2 & 1.0 & 1.0 & 1.0 & 0.0 \\
B & 2 & .2 & 1.0 & 1.0 & 1.0 & 0.0 \\
C & 3 & .2 & 1.0 & 1.0 & 1.0 & 0.0 \\
D & 4 & .2 & 1.0 & 1.0 & 1.0 & 0.0 \\
E & 5 & .2 & 1.0 & 1.0 & 1.0 & 0.0 \\
F & 6 & .2 & 1.0 & 1.0 & 1.0 & 0.0 \\
G & 7 & .2 & 1.0 & 1.0 & 1.0 & 0.0 \\
H & 8 & .2 & 1.0 & 1.0 & 1.0 & 0.0 \\
I2 & 9 & .2 & 1.0 & 1.0 & 1.0 & 0.0 \\
I & 10 & .2 & 1.0 & 1.0 & 1.0 & 0.0 \\
J & 11 & .2 & 1.0 & 1.0 & 1.0 & 0.0 \\
K & 12 & .2 & 1.0 & 1.0 & 1.0 & 0.0 \\
L & 13 & .2 & 1.0 & 1.0 & 1.0 & 0.0 \\
M & 14 & .2 & 1.0 & 1.0 & 1.0 & 0.0 \\
N & 15 & .2 & 1.0 & 1.0 & 1.0 & 0.0 \\
\hline
\end{tabular}


HRU Information

Table 8 listed selective measured basin characteristics for each of the 44 HRUs. There were 27 other model parameters that had to be defined for each HRU. These are defined below. Seven of the 27 parameters were assigned constant values throughout the basin while the remaining 20 parameters were given different values. Data for the 20 parameters are presented in the table that follows the parameter definitions.

IRU, Hydrologic Response Unit identification

IRD, Solar radiation plane index associated with this HRU. Six solar radiation planes were defined under Climate Data. The index and associated identification is as follows:

\begin{tabular}{cc} 
IRD & Solar Radiation Plane \\
\cline { 2 - 2 } 2 & HOR \\
2 & N20 \\
3 & NE10 \\
4 & NE20 \\
5 & ENE1 \\
6 & E20
\end{tabular}

COVDNS, Summer vegetation cover density (decimal) COVDNW, Winter vegetation cover density (decimal)

TRNCF, Transmission coefficient for shortwave radiation through the winter vegetation canopy (decimal form)

SNST, Interception storage capacity of major winter vegetation for snow (inches-water equivalent) RNSTS, Summer interception storage capacity of major vegetation

RNSTW, Winter interception storage capacity of major vegetation (inches)

ITST, Month to look for start of transpiration; assigned a constant value of 4 (April) for each HRU 
ITND, Month transpiration ends; assigned a constant value of 11 (November) for each HRU

CTX, Air temperature coefficient for evapotranspiration computations

TXAJ, Adjustment for maximum air temperature for slope and aspect; assigned a constant value of 0.0 for each HRU

TNAJ, Adjustment for minimum air temperature for slope and aspect; assigned a constant value of 0.0 for each HRU

SMAV, Current available water in soil profile, in inches

REMX, Maximum available water-holding capacity of soil recharge zone, in inches

RECHR, Current available water-holding capacity of soil profile, in inches (.3-15 bars)

SRX, Maximum daily snowmelt infiltration capacity of soil profile, in inches; assigned a constant value of 3.5 for each HRU

SCX, Maximum possible contributing area as proportion of total HRU area (decimal form)

IMPERV, Effective impervious area as proportion of total HRU (decimal form)

RETIP, Maximum retention storage of impervious area; assigned a constant value of 0.0 for each HRU

ISOIL, Soil type, 1 = sand, 2 = loam, 3 = clay; assigned a constant value of 2 for each HRU

SCN, Empirical coefficient that influences the amount of surface runoff

SC1, Empirical coefficient that influences the amount of surface runoff

SMAX, Maximum available water-holding capacity of soil profile, in inches $(.3-15$ bars)

RCF, Subsurface flow routing coefficient

RCP, Subsurface flow routing coefficient

SEP, Constant seepage rate from subsurface to ground-water reservoir, in inches/day

$R C B$, Ground-water flow routing coefficient 


\begin{tabular}{|c|c|c|c|c|c|c|c|}
\hline IRU & IRD & COVDNS & COVDNW & TRNCF & SNST & RNSTS & RNSTW \\
\hline 1 & 1 & 0.0 & 0.0 & 1.0 & 0.0 & 0.0 & 0.0 \\
\hline 2 & $\frac{1}{5}$ & $\begin{array}{l}.8 \\
.6\end{array}$ & $\begin{array}{r}.5 \\
.1\end{array}$ & $\begin{array}{r}.25 \\
.78\end{array}$ & $\begin{array}{l}.0 \\
.01\end{array}$ & $\begin{array}{l}.05 \\
.10\end{array}$ & $\begin{array}{l}.02 \\
.06\end{array}$ \\
\hline 4 & 1 & .0 & .0 & 1.0 & .0 & .0 & 0 \\
\hline 5 & 1 & .8 & .5 & .25 & .0 & .05 & .02 \\
\hline 6 & 4 & .6 & .1 & .78 & .01 & .10 & .06 \\
\hline 7 & 1 & .0 & .0 & 1.0 & .0 & .0 & .0 \\
\hline 8 & 1 & .8 & .5 & .25 & .0 & .05 & .02 \\
\hline 9 & 4 & .6 & .1 & .78 & .01 & .10 & .06 \\
\hline 10 & 1 & .0 & .0 & 1.0 & .0 & .0 & .0 \\
\hline 11 & 1 & .8 & .5 & .25 & .0 & .05 & .02 \\
\hline 12 & 6 & .6 & .1 & .78 & .01 & .10 & .06 \\
\hline 13 & 1 & .0 & .0 & 1.0 & .0 & .0 & .0 \\
\hline 14 & 1 & .8 & .5 & .25 & .0 & .05 & .02 \\
\hline 15 & 4 & .6 & .1 & .78 & .01 & .10 & .06 \\
\hline 16 & 1 & .0 & .0 & 1.0 & .0 & .0 & .0 \\
\hline 17 & 6 & .6 & .1 & .78 & .01 & .10 & .06 \\
\hline 18 & 1 & .0 & .0 & 1.0 & .0 & .0 & .0 \\
\hline 19 & 1 & .8 & .5 & .25 & .0 & .05 & .02 \\
\hline 20 & 2 & .6 & .1 & .78 & .01 & .10 & .06 \\
\hline 21 & 1 & .0 & .0 & 1.0 & .0 & .0 & .0 \\
\hline 22 & 1 & .8 & .5 & .25 & .0 & .05 & .02 \\
\hline 23 & 3 & .6 & .1 & .78 & .01 & .10 & .06 \\
\hline 24 & 1 & .0 & .0 & 1.0 & .0 & .0 & .0 \\
\hline 25 & $\overline{1}$ & .8 & .5 & .25 & .0 & .05 & .02 \\
\hline 26 & 4 & .6 & .1 & .78 & .01 & .10 & .06 \\
\hline 27 & 1 & .0 & .0 & 1.0 & .0 & .0 & .0 \\
\hline 28 & 1 & .8 & .5 & .25 & .0 & .05 & .02 \\
\hline 29 & 3 & .6 & .1 & .78 & .01 & .10 & .06 \\
\hline 30 & 1 & .0 & .0 & 1.0 & .0 & .0 & .0 \\
\hline 31 & 1 & .8 & .5 & .25 & .0 & .05 & .02 \\
\hline 32 & 4 & .6 & .1 & .78 & .01 & .10 & .06 \\
\hline $3 \overline{3}$ & 1 & .0 & .0 & 1.0 & .0 & .0 & .0 \\
\hline 34 & 1 & .8 & .5 & .25 & .0 & .05 & .02 \\
\hline 35 & 4 & .6 & .1 & .78 & .01 & .10 & .06 \\
\hline 36 & 1 & .0 & .0 & 1.0 & .0 & .0 & .0 \\
\hline 37 & 1 & .8 & .5 & .25 & .0 & .05 & .02 \\
\hline 38 & 4 & .6 & .1 & .78 & 01 & .10 & .06 \\
\hline 39 & $i$ & .0 & .0 & 1.0 & .0 & .0 & .0 \\
\hline 40 & 1 & .8 & .5 & .25 & .0 & .05 & .02 \\
\hline 41 & 3 & .6 & .1 & .78 & .01 & .10 & .06 \\
\hline 42 & 1 & .0 & .0 & 1.0 & .0 & .0 & .0 \\
\hline 43 & 1 & .8 & .5 & .25 & .0 & .05 & .02 \\
\hline 44 & 3 & .6 & .1 & .78 & .01 & .10 & .06 \\
\hline
\end{tabular}




\begin{tabular}{|c|c|c|c|c|c|c|}
\hline IRU & CTX & SMAV & REMXW & RECHR & $\operatorname{scx}$ & IMPERV \\
\hline $\begin{array}{l}1 \\
2 \\
3 \\
4 \\
5 \\
6 \\
7 \\
8 \\
9 \\
10 \\
11 \\
12 \\
13 \\
14 \\
15 \\
16 \\
17 \\
18 \\
19 \\
20 \\
21 \\
22 \\
23 \\
24 \\
25 \\
26 \\
27 \\
28 \\
29 \\
30 \\
31 \\
32 \\
33 \\
34 \\
35 \\
36 \\
37 \\
38 \\
39 \\
40 \\
41 \\
42 \\
43 \\
44\end{array}$ & $\begin{array}{l}19.59 \\
19.59 \\
19.59 \\
19.87 \\
19.87 \\
19.87 \\
20.27 \\
20.27 \\
20.27 \\
20.37 \\
20.37 \\
20.37 \\
19.97 \\
19.97 \\
19.97 \\
20.45 \\
20.45 \\
20.42 \\
20.42 \\
20.42 \\
20.47 \\
20.47 \\
20.47 \\
20.47 \\
20.47 \\
20.47 \\
20.47 \\
20.47 \\
20.47 \\
20.77 \\
20.77 \\
20.77 \\
20.62 \\
20.62 \\
20.62 \\
20.92 \\
20.92 \\
20.92 \\
21.02 \\
21.02 \\
21.02 \\
21.12 \\
21.12 \\
21.12\end{array}$ & $\begin{array}{l}2.350 \\
2.350 \\
2.350 \\
2.320 \\
2.320 \\
2.320 \\
2.503 \\
2.503 \\
2.503 \\
2.503 \\
2.503 \\
2.503 \\
2.300 \\
2.300 \\
2.300 \\
2.503 \\
2.503 \\
2.503 \\
2.500 \\
2.503 \\
2.503 \\
2.503 \\
2.500 \\
1.900 \\
1.900 \\
1.900 \\
2.850 \\
2.850 \\
2.850 \\
3.600 \\
3.600 \\
3.600 \\
2.500 \\
2.500 \\
2.500 \\
3.300 \\
3.300 \\
3.300 \\
2.500 \\
2.500 \\
2.500 \\
2.500 \\
2.500 \\
2.500\end{array}$ & $\begin{array}{r}0.1274 \\
.1274 \\
.1274 \\
.1288 \\
.1288 \\
.1288 \\
.1200 \\
.1200 \\
.1200 \\
.1200 \\
.1200 \\
.1200 \\
.1204 \\
.1204 \\
.1204 \\
.1200 \\
.1200 \\
.1200 \\
.1200 \\
.1200 \\
.1200 \\
.1200 \\
.1200 \\
.1209 \\
.1209 \\
.1209 \\
.1316 \\
.1316 \\
.1316 \\
.1500 \\
.1500 \\
.1500 \\
.1200 \\
.1200 \\
.1200 \\
.1412 \\
.1412 \\
.1412 \\
.1600 \\
.1600 \\
.1600 \\
.1496 \\
.1496 \\
.1496\end{array}$ & $\begin{array}{l}0.0500 \\
.0500 \\
.0500 \\
.0500 \\
.0500 \\
.0500 \\
.0500 \\
.0500 \\
.0500 \\
.0500 \\
.0500 \\
.0500 \\
.0500 \\
.0500 \\
.0500 \\
.0500 \\
.0500 \\
.0500 \\
.0500 \\
.0500 \\
.0500 \\
.0500 \\
.0500 \\
.0500 \\
.0500 \\
.0500 \\
.0500 \\
.0500 \\
.0800 \\
.0500 \\
.0500 \\
.0500 \\
.0500 \\
.0500 \\
.0500 \\
.0500 \\
.0500 \\
.0500 \\
.0500 \\
.0500 \\
.0500 \\
.0500 \\
.0500 \\
.0500\end{array}$ & $\begin{array}{l}0.70 \\
.50 \\
.50 \\
.70 \\
.50 \\
.50 \\
.70 \\
.50 \\
.50 \\
.70 \\
.50 \\
.50 \\
.70 \\
.50 \\
.50 \\
.70 \\
.50 \\
.70 \\
.50 \\
.50 \\
.70 \\
.50 \\
.50 \\
.70 \\
.50 \\
.50 \\
.70 \\
.50 \\
.50 \\
.70 \\
.50 \\
.50 \\
.70 \\
.50 \\
.50 \\
.70 \\
.50 \\
.50 \\
.70 \\
.50 \\
.50 \\
.70 \\
.50 \\
.50\end{array}$ & $\begin{array}{l}0.0000 \\
.0000 \\
.0063 \\
.0000 \\
.0000 \\
.0048 \\
.0000 \\
.0000 \\
.0765 \\
.0000 \\
.0000 \\
.0026 \\
.0000 \\
.0000 \\
.0027 \\
.0000 \\
.0033 \\
.0000 \\
.0000 \\
.0000 \\
.0000 \\
.0000 \\
.0000 \\
.0000 \\
.0000 \\
.0000 \\
.0000 \\
.0000 \\
.0018 \\
.0000 \\
.0000 \\
.0073 \\
.0000 \\
.0000 \\
.0008 \\
.0000 \\
.0000 \\
.0033 \\
.0000 \\
.0000 \\
.0025 \\
.0000 \\
.0000 \\
.0010\end{array}$ \\
\hline
\end{tabular}




\begin{tabular}{|c|c|c|c|c|c|c|c|}
\hline IRU & SCN & SCl & SMAX & RCF & RCP & SEP & $\underline{\mathrm{RCB}}$ \\
\hline $\begin{array}{r}1 \\
2 \\
3 \\
4 \\
5 \\
6 \\
7 \\
8 \\
9 \\
10 \\
11 \\
12 \\
13 \\
14 \\
15 \\
16 \\
17 \\
18 \\
19 \\
20 \\
21 \\
22 \\
23 \\
24 \\
25 \\
26 \\
27 \\
28 \\
29 \\
30 \\
31 \\
32 \\
33 \\
34 \\
35 \\
36 \\
37 \\
38 \\
39 \\
40 \\
41 \\
42 \\
43 \\
44\end{array}$ & $\begin{array}{l}0.0011 \\
.0011 \\
.0011 \\
.0009 \\
.0009 \\
.0009 \\
.0009 \\
.0009 \\
.0009 \\
.0009 \\
.0009 \\
.0009 \\
.0009 \\
.0009 \\
.0009 \\
.0009 \\
.0009 \\
.0009 \\
.0009 \\
.0009 \\
.0009 \\
.0009 \\
.0009 \\
.0009 \\
.0009 \\
.0009 \\
.0009 \\
.0009 \\
.0009 \\
.0009 \\
.0009 \\
.0009 \\
.0009 \\
.0009 \\
.0009 \\
.0009 \\
.0009 \\
.0009 \\
.0009 \\
.0009 \\
.0009 \\
.0009 \\
.0009 \\
.0009\end{array}$ & $\begin{array}{r}0.3428 \\
.3428 \\
.3428 \\
.4000 \\
.4000 \\
.4000 \\
.4000 \\
.4000 \\
.4000 \\
.4000 \\
.4000 \\
.4000 \\
.4000 \\
.4000 \\
.4000 \\
.4000 \\
.4000 \\
.4000 \\
.4000 \\
.4000 \\
.4000 \\
.4000 \\
.4000 \\
.5000 \\
.5000 \\
.5000 \\
.4000 \\
.4000 \\
.4000 \\
.4000 \\
.4000 \\
.4000 \\
.4000 \\
.4000 \\
.4000 \\
.4000 \\
.4000 \\
.4000 \\
.3524 \\
.3524 \\
.3524 \\
.4000 \\
.4000 \\
.4000\end{array}$ & $\begin{array}{l}3.970 \\
3.970 \\
3.970 \\
4.916 \\
4.916 \\
4.916 \\
4.795 \\
4.795 \\
4.795 \\
4.795 \\
4.795 \\
4.795 \\
4.716 \\
4.716 \\
4.716 \\
4.795 \\
4.795 \\
5.006 \\
5.006 \\
5.006 \\
4.928 \\
4.928 \\
4.928 \\
3.874 \\
3.874 \\
3.874 \\
4.928 \\
4.928 \\
4.928 \\
4.928 \\
4.928 \\
4.928 \\
5.006 \\
5.006 \\
5.006 \\
6.884 \\
6.884 \\
6.884 \\
5.006 \\
5.006 \\
5.006 \\
5.006 \\
5.006 \\
5.006\end{array}$ & $\begin{array}{r}0.1000 \\
.1000 \\
.1000 \\
.1500 \\
.1500 \\
.1500 \\
.1566 \\
.1566 \\
.1566 \\
.1566 \\
.1566 \\
.1566 \\
.1651 \\
.1651 \\
.1651 \\
.1566 \\
.1566 \\
.3400 \\
.3400 \\
.3400 \\
.2300 \\
.2300 \\
.2300 \\
.4200 \\
.4200 \\
.4200 \\
.2300 \\
.2300 \\
.2300 \\
.2300 \\
.2300 \\
.2300 \\
.2700 \\
.2700 \\
.2700 \\
.5466 \\
.5466 \\
.5466 \\
.3111 \\
.3111 \\
.3111 \\
.3111 \\
.3111 \\
.3111\end{array}$ & $\begin{array}{r}0.2000 \\
.2000 \\
.2000 \\
.2000 \\
.2000 \\
.2000 \\
.2000 \\
.2000 \\
.2000 \\
.2000 \\
.2000 \\
.2000 \\
.2000 \\
.2000 \\
.2000 \\
.2000 \\
.2000 \\
.3000 \\
.3000 \\
.3000 \\
.2000 \\
.2000 \\
.2000 \\
.2000 \\
.2000 \\
.2000 \\
.2000 \\
.2000 \\
.2000 \\
.2000 \\
.2000 \\
.2000 \\
.2000 \\
.2000 \\
.2000 \\
.2000 \\
.2000 \\
.2000 \\
.2000 \\
.2000 \\
.2000 \\
.2000 \\
.2000 \\
.2000\end{array}$ & $\begin{array}{l}0.450 \\
.450 \\
.450 \\
.129 \\
.129 \\
.129 \\
.125 \\
.125 \\
.125 \\
.125 \\
.125 \\
.125 \\
.125 \\
.125 \\
.125 \\
.125 \\
.125 \\
.125 \\
.125 \\
.125 \\
.120 \\
.120 \\
.120 \\
.050 \\
.050 \\
.050 \\
.120 \\
.120 \\
.120 \\
.120 \\
.120 \\
.120 \\
.150 \\
.150 \\
.150 \\
.125 \\
.125 \\
.125 \\
.255 \\
.255 \\
.255 \\
.100 \\
.100 \\
.100\end{array}$ & $\begin{array}{l}0.0372 \\
.0372 \\
.0372 \\
.0178 \\
.0178 \\
.0178 \\
.0099 \\
.0099 \\
.0099 \\
.0067 \\
.0067 \\
.0067 \\
.0099 \\
.0099 \\
.0099 \\
.0067 \\
.0067 \\
.0149 \\
.0149 \\
.01449 \\
.0300 \\
.0300 \\
.0300 \\
.0020 \\
.0020 \\
.0020 \\
.0300 \\
.0300 \\
.0300 \\
.0300 \\
.0300 \\
.0300 \\
.0100 \\
.0100 \\
.0100 \\
.0094 \\
.0094 \\
.0094 \\
.0200 \\
.0200 \\
.0200 \\
.0065 \\
.0065 \\
.0065\end{array}$ \\
\hline
\end{tabular}




\section{APPENDIX B}

Observed and computed mean daily discharge hydrographs for 11 gaging stations in the Tug Fork basin for water years 1977-1980. 


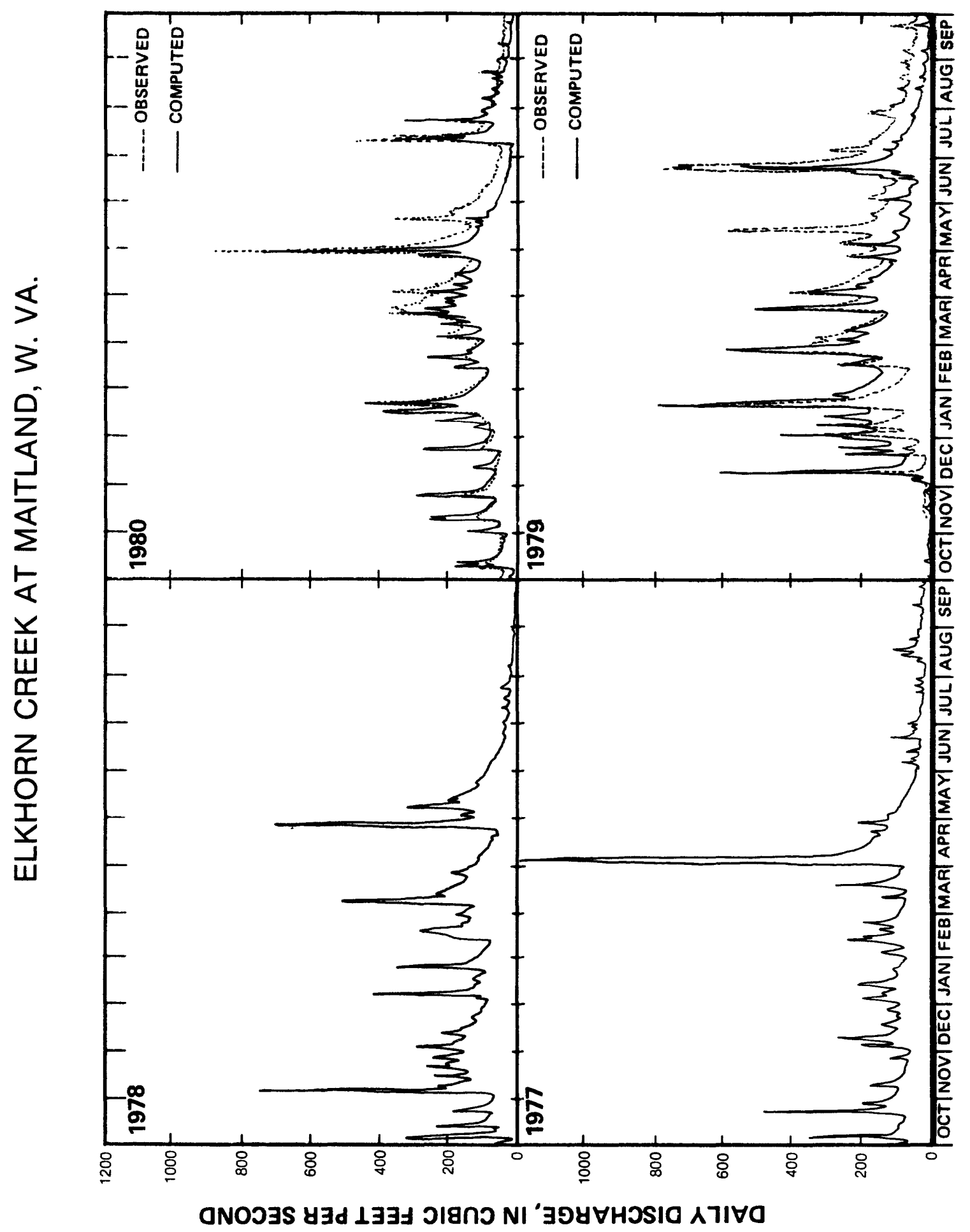




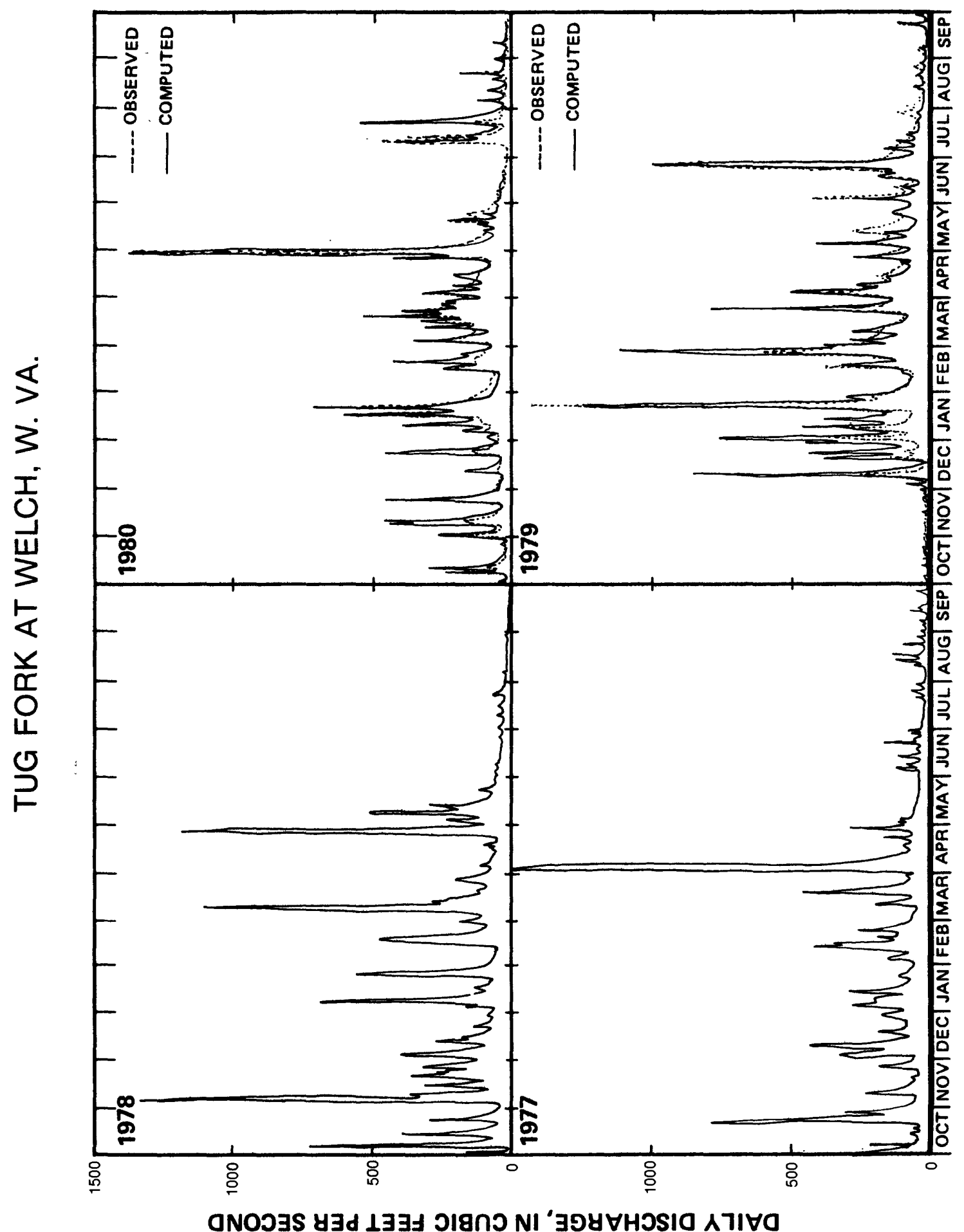




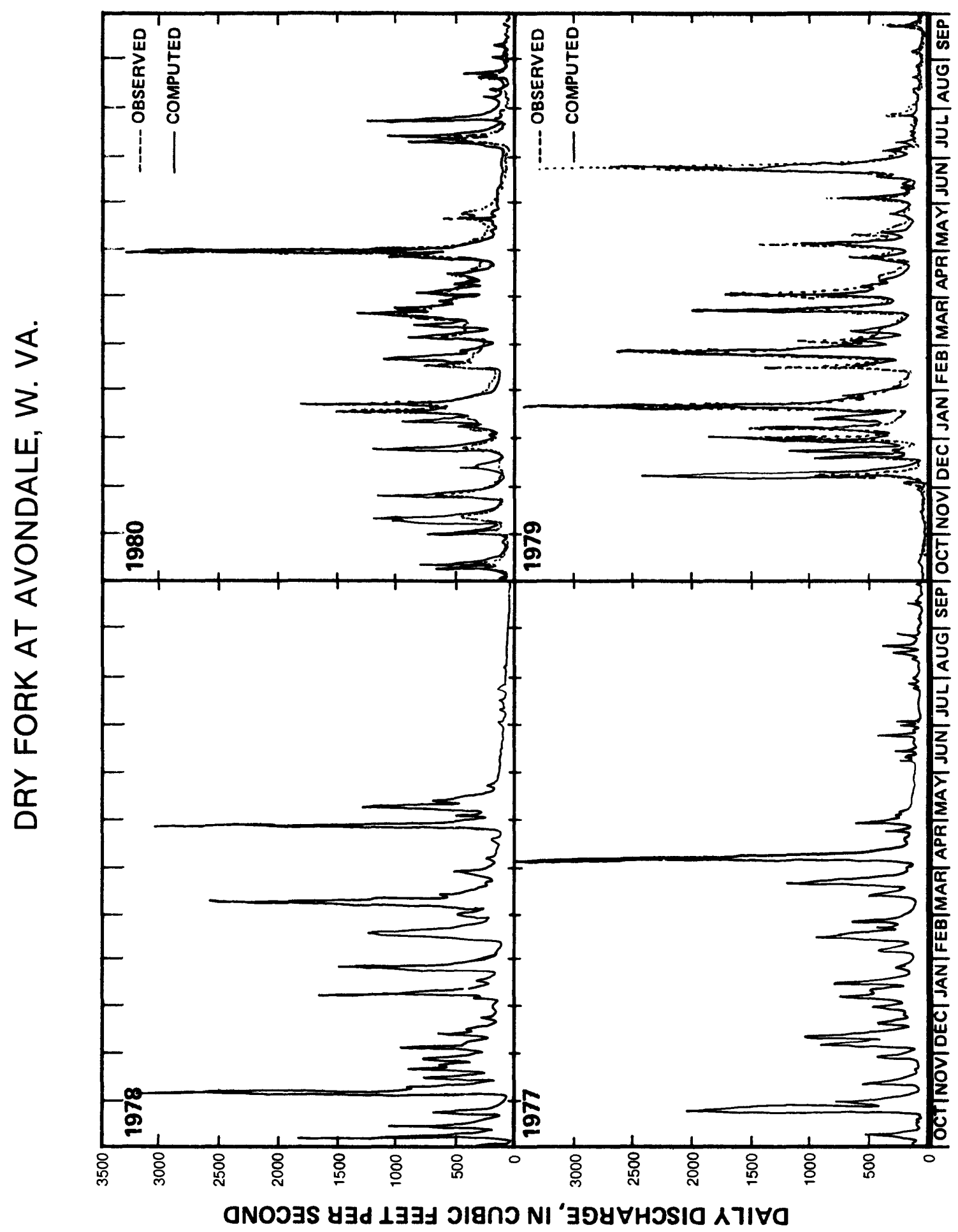




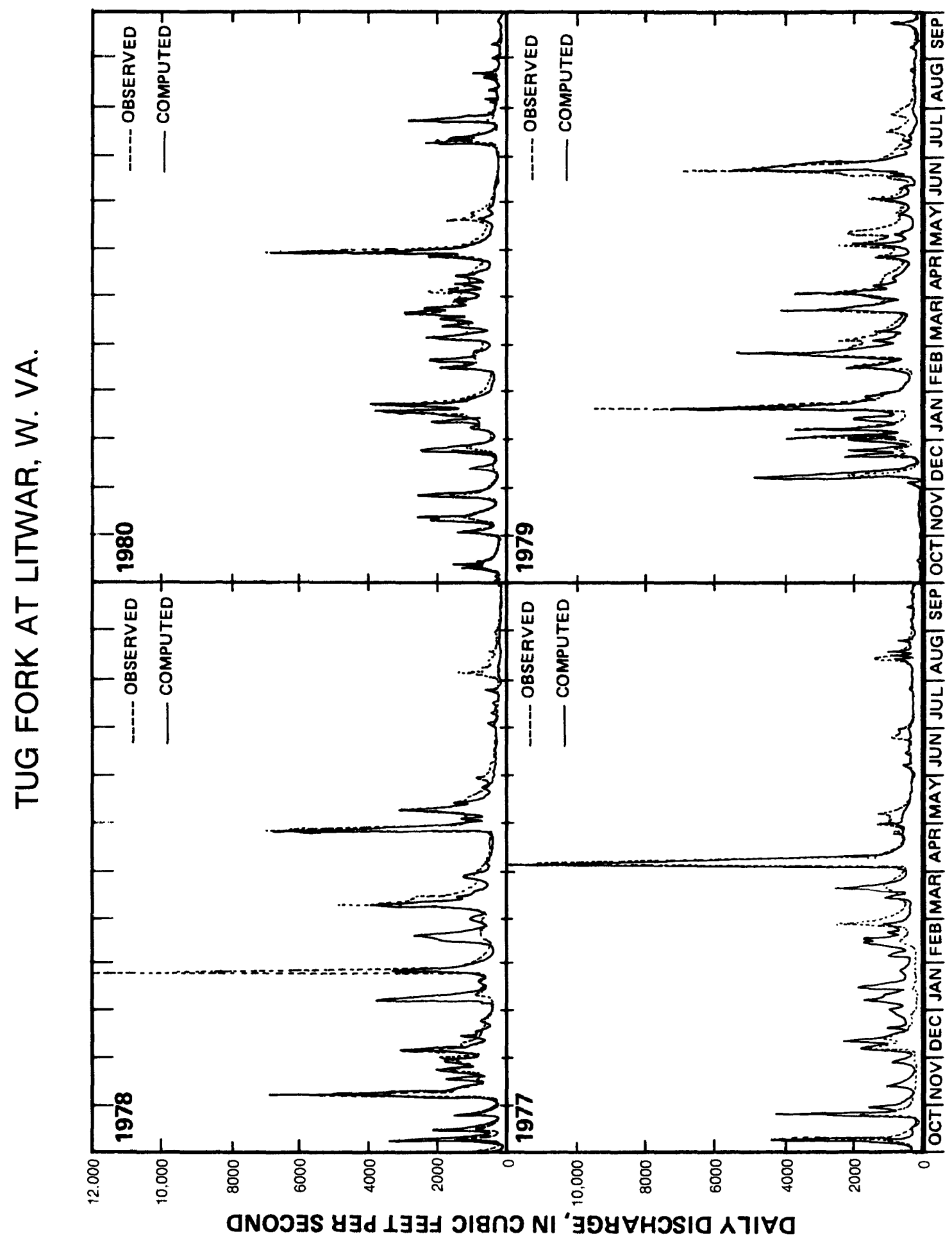




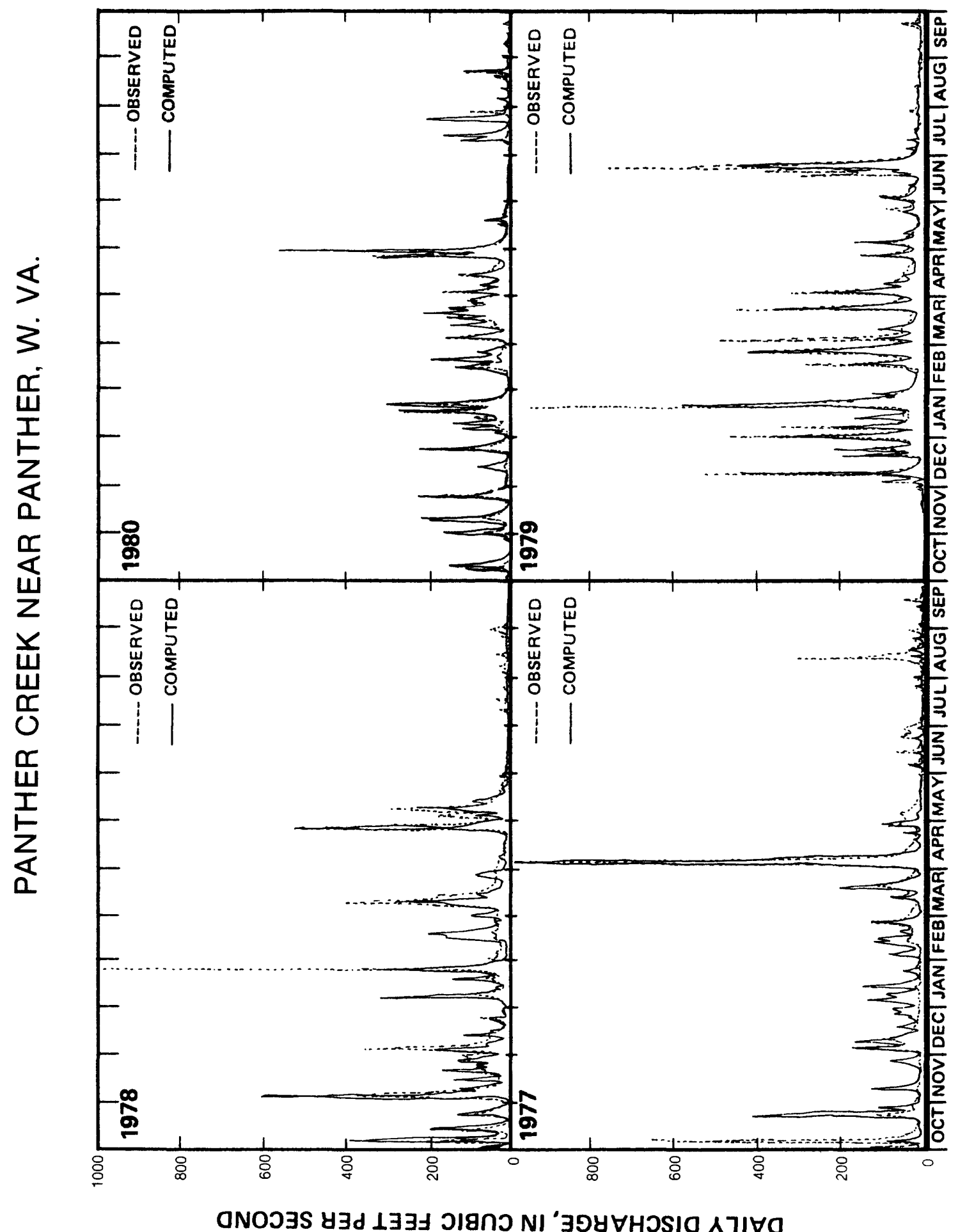




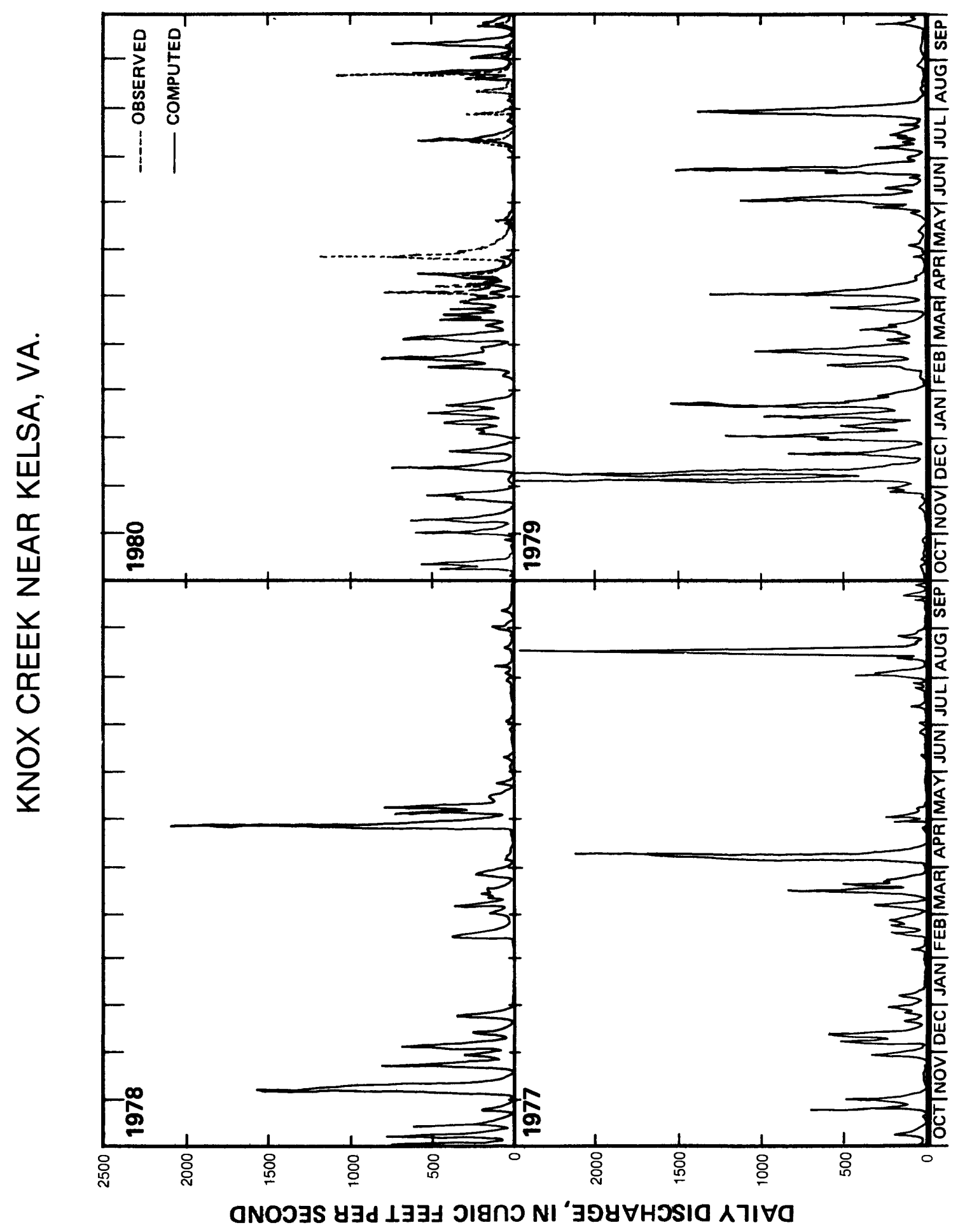




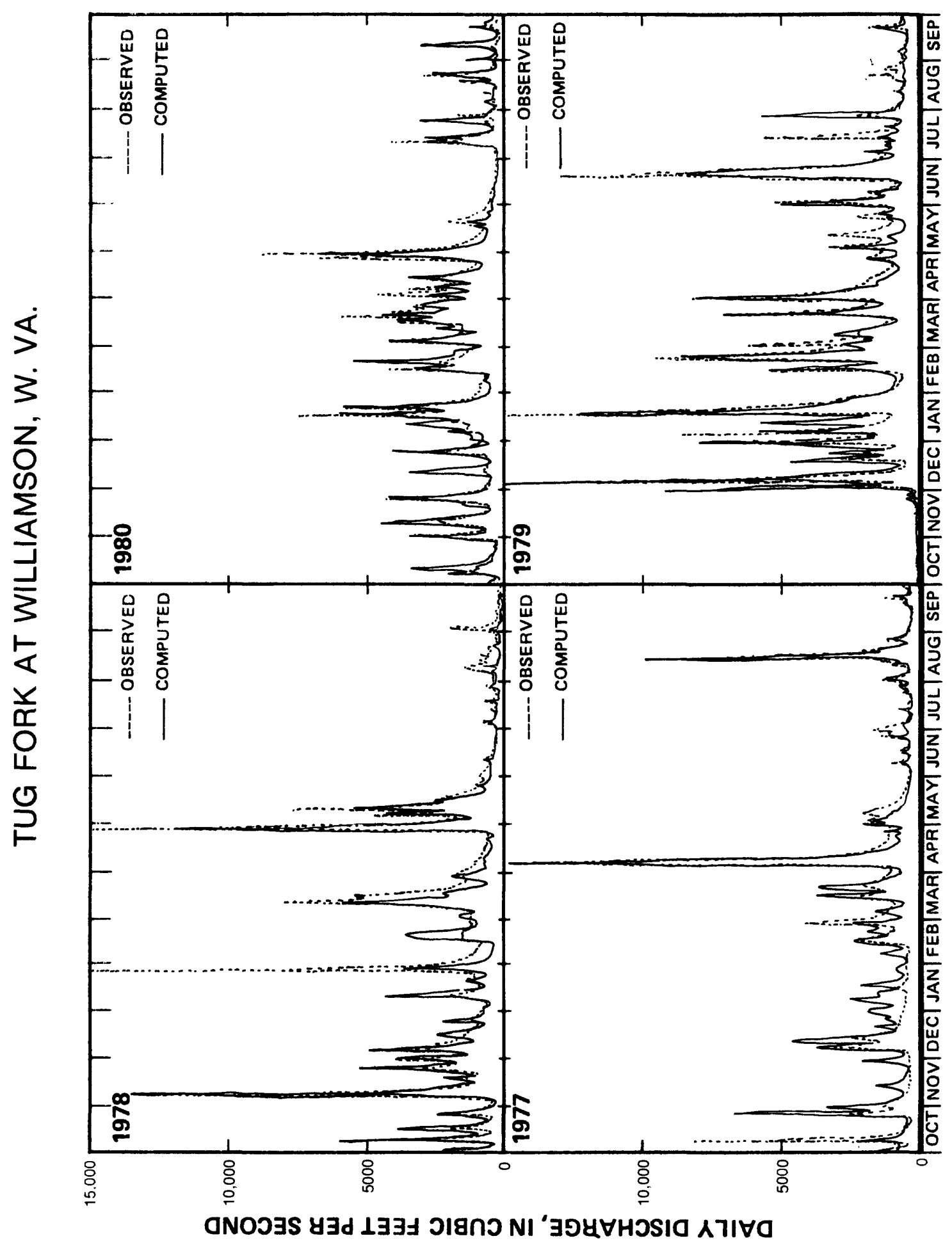




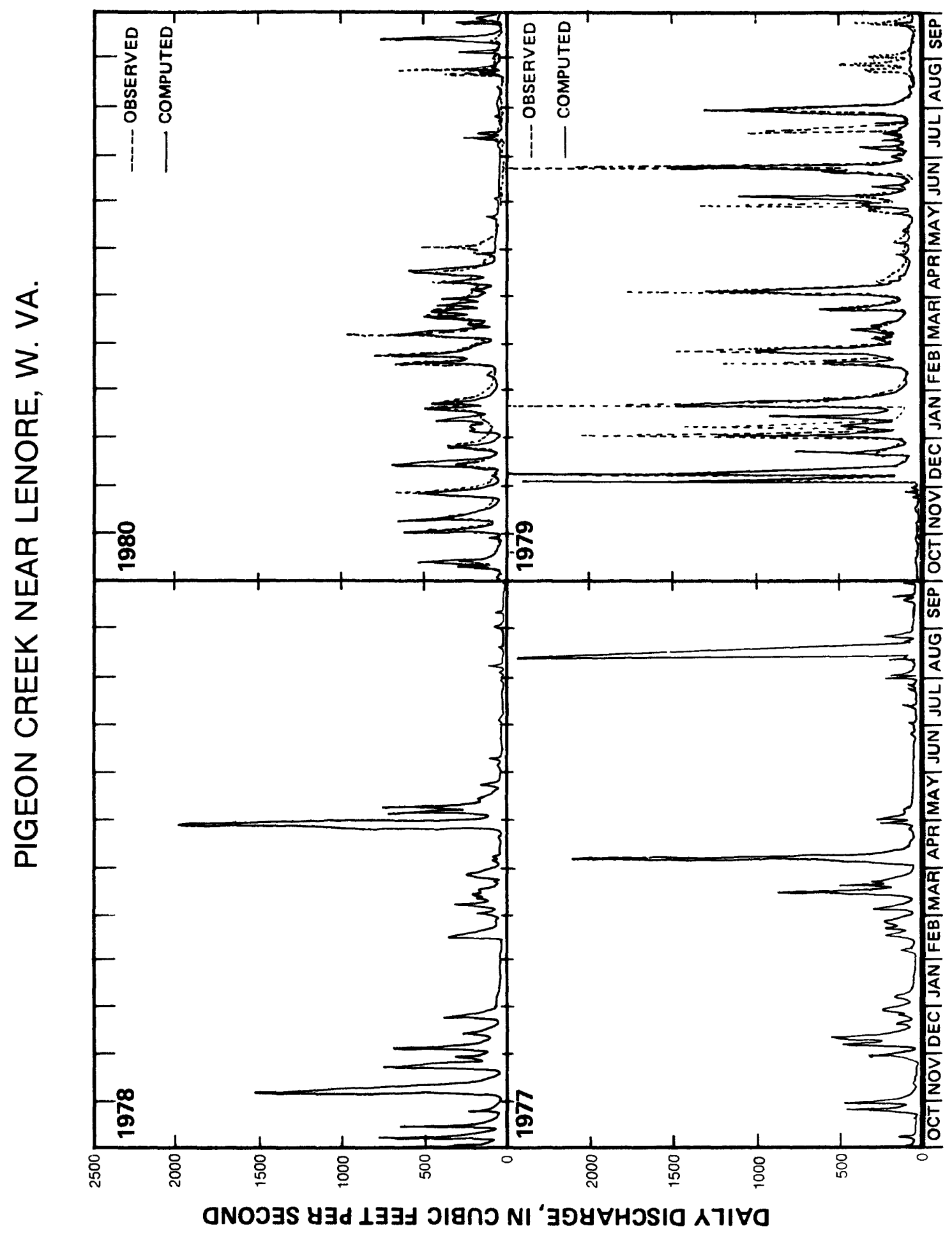




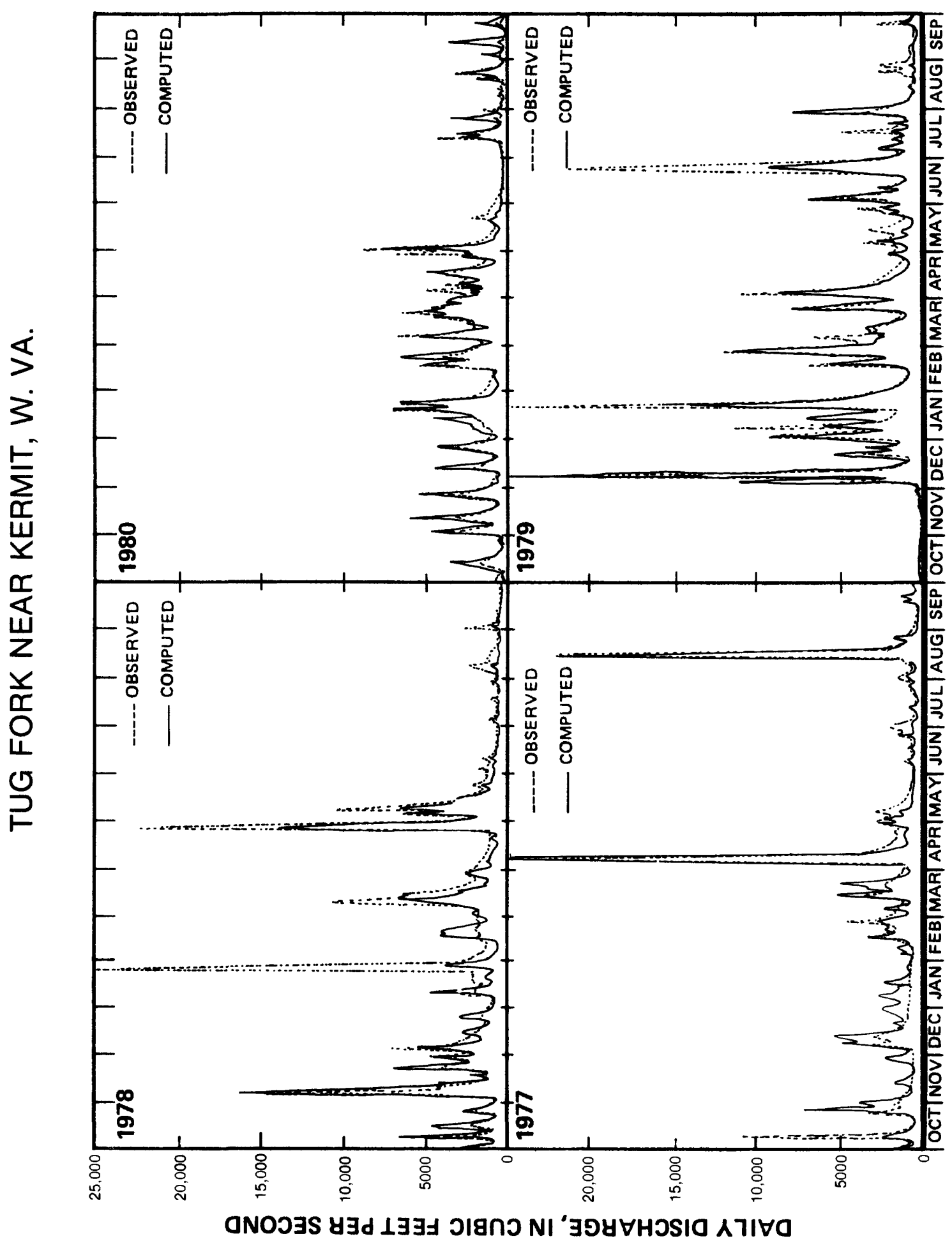




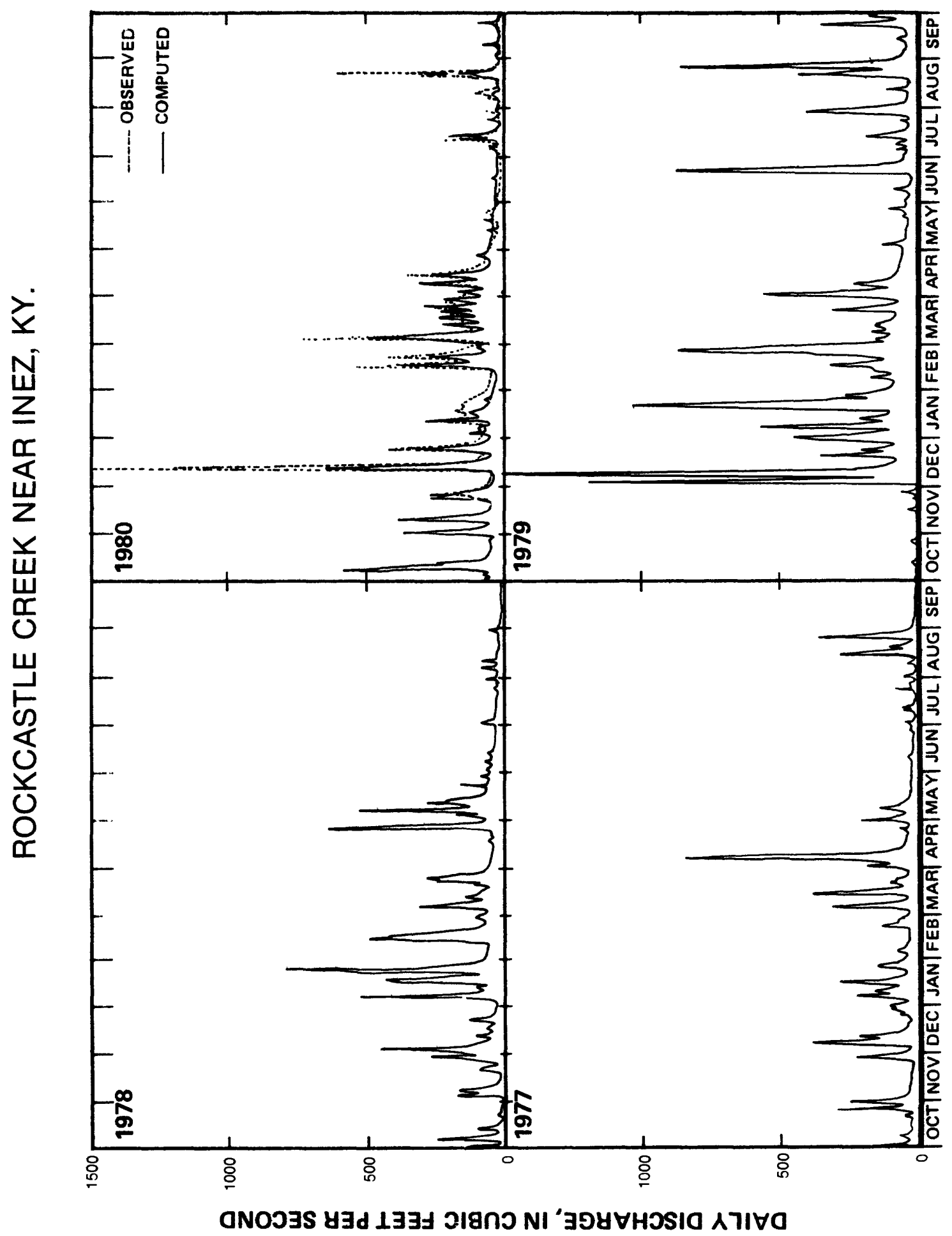




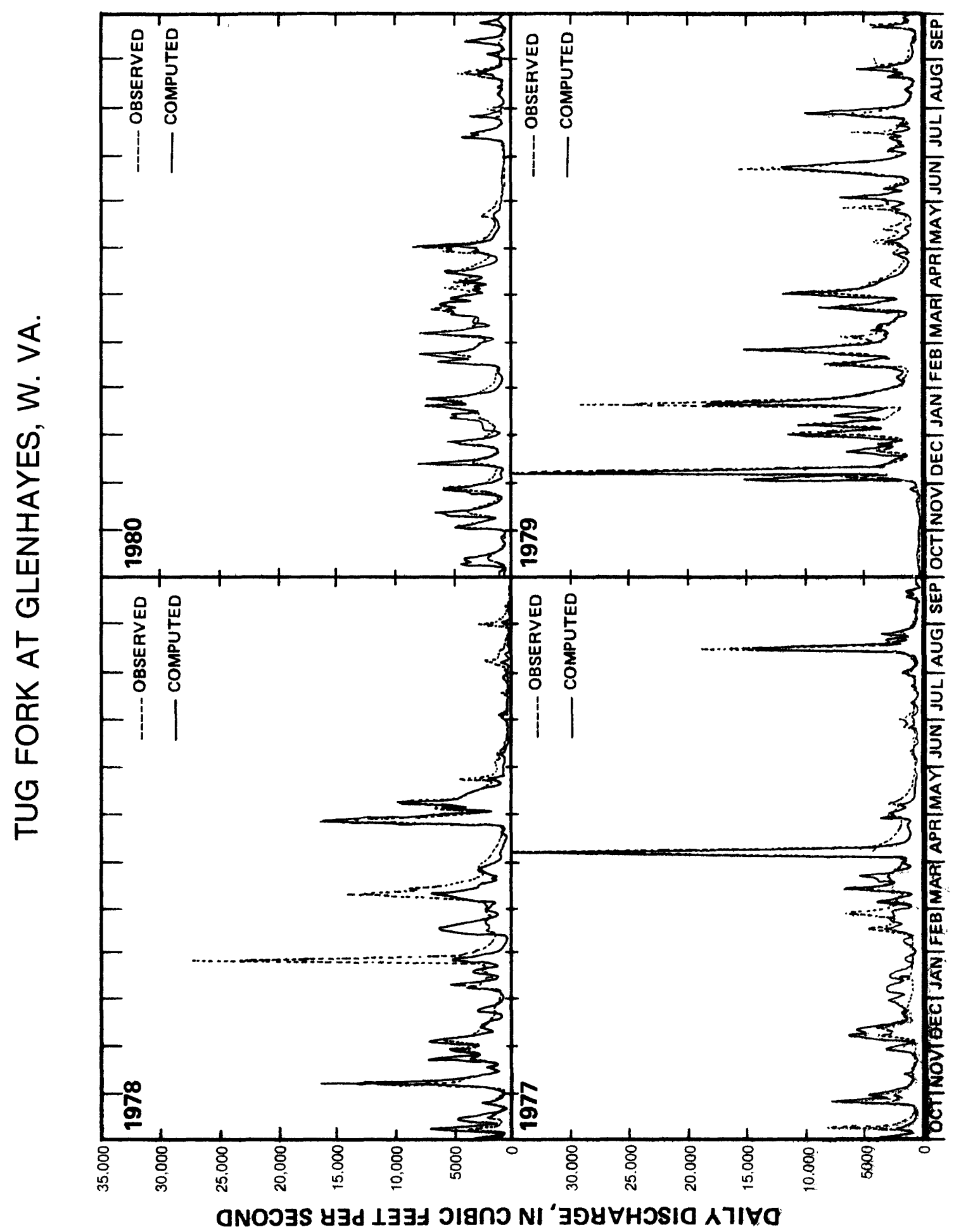

